\title{
Other Ways to Skin a Cat:
}

The Social Identity Jobs-to-be-done theory as it applies to independent magazines surviving technological disruption

By Emily Kennedy

A thesis submitted to the Faculty of Graduate and Postdoctoral Affairs in partial fulfillment of the requirements of the degree of

Master

of

Journalism

Carleton University

Ottawa, Ontario

(C) 2016

Emily Kennedy 


\section{Abstract}

This cross-disciplinary study of print magazines facing technological disruption asks: Why do we like print magazines? Why are they important to society? What business strategies appear to be working in protecting publications from technological disruption?

From a review of technological disruption to magazines since their inception, this study finds that magazines that survived earlier disruptive periods did so through content innovation. However, content is not enough to protect against the most recent technological disruption caused by the Internet and mobile devices.

Instead, a combined theory is proposed, called the Social Identity Jobs-to-bedone (SIJ) theory, purporting that we seek print magazines for their role defining our social identities. From an analysis of four case studies of independent magazines at the niche, city, national and international level that are surviving technological disruption, it is argued that the SIJ theory can help publishers determine what areas of their business to protect and expand. 


\section{Acknowledgments}

I am pleased to have the opportunity to thank the many colleagues, friends and faculty members who have helped me with this research project. I am most indebted to Dr. Christopher Waddell, the supervisor of this thesis, for sharing his research expertise and wisdom in connection with this project. I am also appreciative of his constant willingness to offer helpful answers, advice and quick replies to my many questions. Equally, I am very thankful to Dr. Ian Lee in the Sprott School of Business, for his willingness to take me on as a directed studies student, and share his research and expert understanding of the intersection of media and business. I am also very grateful to Mary Chouieri, Graduate Administrator, for her guidance through my master's education. Thank you to Dr. Christopher Dornan, Graduate School Supervisor, for several letters of reference and for his ongoing enthusiasm.

Two notable assists made this research possible. The first, a bursary award from the school that allowed me to travel to London, U.K., to attend the Modern Magazine Conference and meet with Barbara Rowlands, Steve Watson, and Tyler Brûlé. Like many types of research, a hypothesis can be formed, but you will only learn the outcome by going out in the world and seeing for yourself. I found that from abroad, the independent magazines I read about looked much different than after meeting their publishers and hearing their ideas in person. In addition, like a journalist, I went into this research without an angle. The opportunity to meet many independent magazine publishers from around the world and serendipitously come 
upon their unique views and business concepts was invaluable. Thank you to Carleton University and the Faculty of Public Affairs for supporting travel with (at the time of application) unknown outcomes.

The second, was a two-week internship at Palm Springs Life Magazine. Thank you to the publication and its staff who welcomed me, and my many questions.

In addition, thank you to the numerous staff at The Walrus, Tom Tom Magazine and Monocle. Thanks also to Jason Aston for his kind help navigating government data. I would like to add a special word of appreciation to Dr. Janet Boileau, whose fearless leadership of independent title Taste\&Travel Magazine first stimulated my thoughts on this subject, and for successfully recommending me to the program. Thank you to Garfield Corbett for encouraging and teaching me an academic and social curiosity that will last a lifetime. Most importantly, thank you to my parents, David Kennedy and Martwyn Kennedy, for their support in seeing me follow my passions; and thank you to Mark Laforest, for his A-plus love and encouragement. 


\section{Table of Contents}

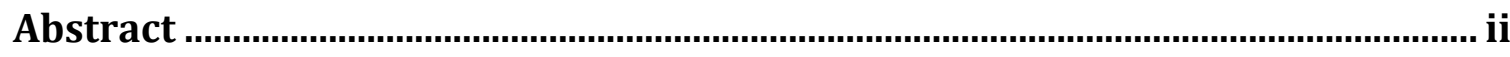

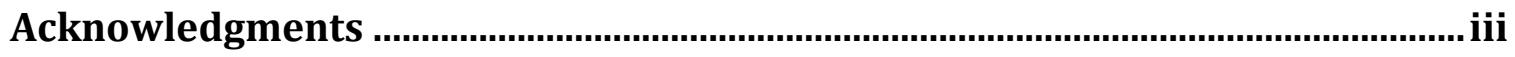

List of Tables and Figures........................................................................................... vi

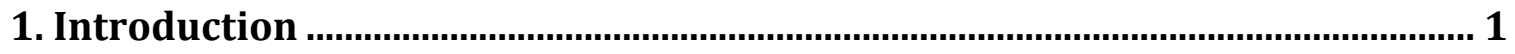

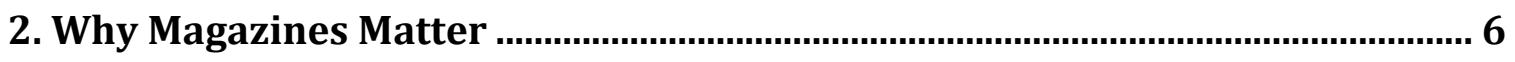

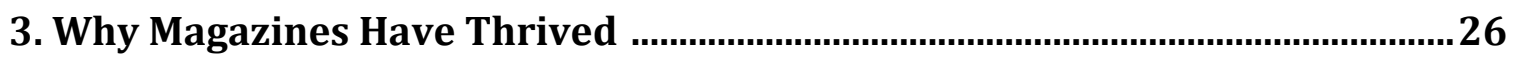

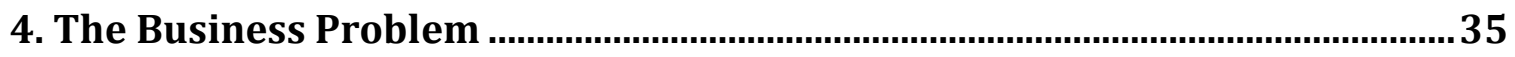

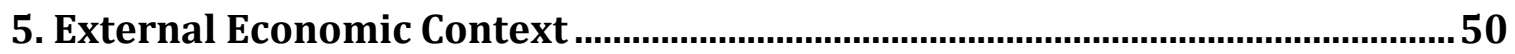

6. Case Study 1 (Niche) Tom Tom Magazine ............................................................58

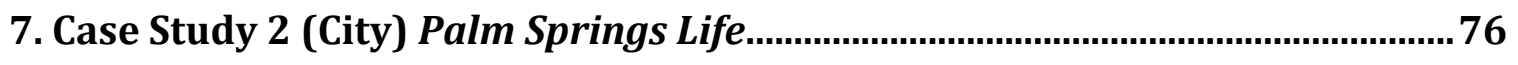

8. Case Study 3 (National) The Walrus ............................................................... 93

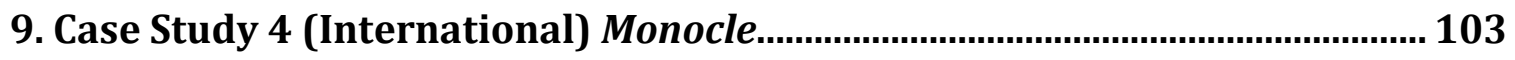

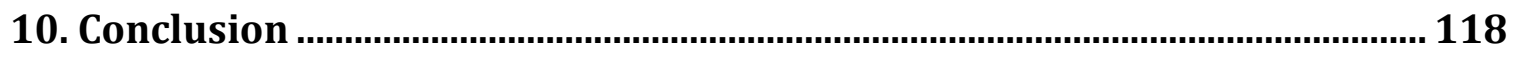

Appendix A: The Walrus Balance Sheets and Income Statements .................. 128

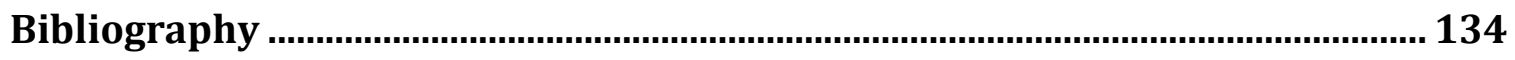




\section{List of Tables and Figures}

\section{Tables}

6.0 Tom Tom Magazine Revenue 2015 .............................................................64

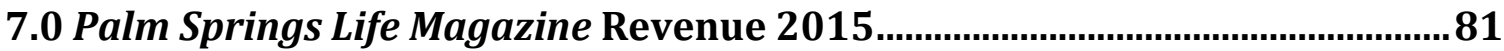

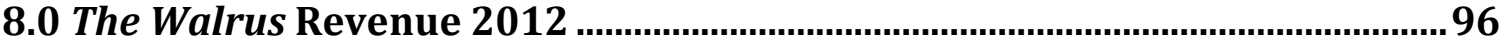

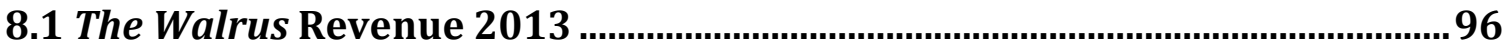

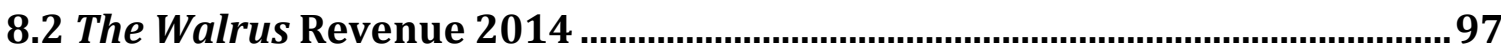

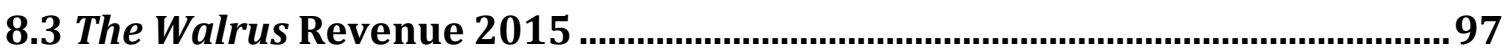

\section{Figures}

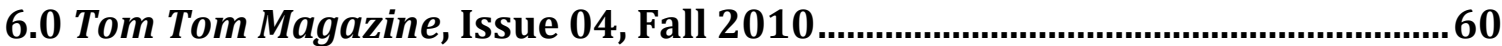

6.1 Tom Tom Magazine, Issue 24, Winter 2015/2016 ........................................61

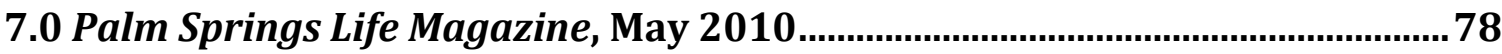

7.1 Palm Springs Life Magazine, April 2016 ............................................................79

7.2 Palm Springs Life Magazine, March 2016 (Fashion) .......................................90

7.3 Palm Springs Life Magazine, March 2016 (Festival) .....................................91

7.4 Palm Springs Life Magazine, March 2016 (Tennis) .........................................91

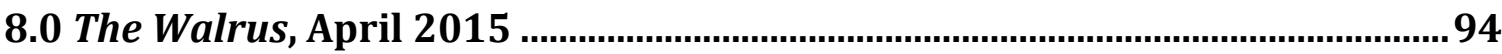

9.0 Monocle, October 2015 (airport newsstand copy) ……................................. 106

9.1 Monocle Shop-in-shop, from wholesale brochure …........................................ 109

9.2 Section from Kisokafé franchise brochure ................................................... 111 


\section{Introduction}

Steven: What's a good, modern business model?

Jeremy: The first, most obvious thing is this: there's no single way. If you look back just 10 years, or certainly 20 years, there was quite a simple business model: print something, put it out there, and between advertising sales and copy sales you were minted... unless you really messed it up of course. Today, people have to be clearer than ever about what it is they're trying to do: from what they plan to make, to who is going to buy and read it, (Gregor 13).

Having "clarity" of intention in a creative, complex, and competitive industry is as valuable as the clarity of a flawless diamond. For magazines, any kind of signpost to help guide decision making is urgently vital in the industry's path to survival.

Although print industry nihilists may argue print is down for the count, the magazines profiled in this thesis show they've got plenty of fight left in them.

On the surface, magazine business models appear as simply the combination of advertising, subscriptions and single copy sales. But upon closer inspection, these pillar revenue streams exist in delicate balance. Add to this new "alternative" revenue streams magazines engage in, and the models become increasingly complex.

In light of the most recent technological disruption, surviving magazines are finding there's more than one way to skin a cat.

A glance across the magazine horizon shows a variety of alternative revenue streams. For example, Porter Magazine runs a high-fashion retail website; The Big 
Issue operates a foundation and an online shop that helps those affected by poverty; Little White Lies hosts monthly movie pub quizzes; Reader's Digest offers cooking lessons; Butt magazine operates an online dating portal for gay men; $032 \mathrm{c}$ runs a club and hosts bar nights in their workshop for its members; San Diego Magazine hosts four awards nights and co-organizes a summer arts festival; Lucky Peach records and presses vinyl records; Spacing works with local designers to create unique pieces for sale in their Toronto store.

The case studies reviewed in this thesis pull back the curtain on how magazines are seeking revenue, showing not-for-profit models, events, merchandise, educational programs, creative ad agency work and more.

With so many directions for magazines to go, what path do they choose? In discerning similarities and patterns in this group of magazines surviving disruption, a new theory combining social psychology with disruptive innovation business theory is proposed and applied.

Independent magazines were chosen as a focus because they can make innovative business decisions without heavy influence from shareholders. These magazines naturally seek alternatives and additions to the legacy model, deriving their very identity from challenging mainstream (Newman 16). In addition, crisissuch as that posed by technological disruption-is not new for independent magazines:

"Independent media are in a nearly perpetual state of crisis. Such crises may be economic-in terms of lack of funding as well as ethical or socio-political judgments over sources of funding — or formal—in terms of the kinds of cultural goods produced and their appeal to an (economically viable) audience" (Bennett 19). 
"Independent magazines indulge their very magazine-ness. Reversing the manufacturing commoditization of the mainstream, their publishers relish the use of heavier weights and different types of paper, they use extra inks and experiment with other special effects. For them, a magazine is as much as anything an object, a physical item endowed with qualities that appeal to multiple senses-smell, sound, touch as well as sight. Their makers are openminded about what a magazine can be," (Leslie 11).

This study will hopefully make a contribution to the examination of business models in the independent magazine context and, through a new combination theory, offer guidance in determining what aspect of a magazine's business to guard against disruption and what aspects to expand into new revenue streams.

\section{Definitions}

For the sake of variety, the terms magazine, periodical, and publication have been used interchangeably in this study. The term "magazine" refers to a printed and bound publication that appears at regular intervals in a year. Since this study concerns itself with independent magazines, it is further limited to print publications "whose parent company owns fewer than three titles" ("Magazines Canada Policy Governance Model and Operational Guidelines").

When reference is made to "alternative revenue" streams, this is meant as alternative to the traditional trifecta of advertisements, subscriptions and single copy sales revenue.

The term "creative agency" is used to refer to a company that engages in advertising, branding, design, or content strategy work for clients. 


\section{Limitations}

"It will be no surprise to those in the industry to know that publishers of individual magazines are quite reticent to divulge proprietary information such as actual advertising revenue, return rates, acquisition plans or budgets," writes author Benjamin Compaine in his 1981 book The Business of Consumer Magazines. This "reticent" tendency continues today, even more so for independent publishers whose books are kept tightly closed. Independent publishers are often not members of industry statistics-gathering bodies (such as The Magazine Publishers Association) or tallied by circulation audit bureaus.

Many sources for general industry information require one to be a paying member to access full reports (e.g., the Price Waterhouse Cooper Global Entertainment \& Media Outlook, and reports produced by the International Federation of Periodical Publishers, FIPP). The purpose of this note is not to criticize, but to highlight that there is a large amount of data collected in the industry, yet unavailable to researchers ${ }^{1}$. Furthermore, data collected is not subcategorized into independent publishers, and so a review of these sources does not reflect the independent magazine industry on its own.

\footnotetext{
1 The author requested access as a student researcher to events and many industry reports not accessible via the university library, e.g., $\mathrm{PwC}$, where a single user membership to access the report is US $\$ 500$, denied the request; FIPP granted access to 2015 reports only; and IMAG offered a "student discounted" price of US $\$ 749$ to attend their annual conference.
} 
Although not all content is created equal, for the purpose of this study it is treated as such. This study is not a discursive study of magazine content, nor does it look at graphic design.

This study is limited to independent magazines that publish and sell at least one printed product. The research does not examine newspapers, neither does the research examine brand magazines who do not see revenue from the sale of a printed product. The research is limited to English language periodicals. 


\section{WHY MAGAZINES MATTER}

"An ordinary life examined closely reveals itself to be exquisite and exceptional" -Susan Orlean, Esquire

In a 2007 YouTube video, a violinist busks in a Washington D.C. metro station at morning rush hour. It is not much to look at: a medium-wide angle, single shot. The grainy video has the cinematic quality of a security camera. As you might expect, most people ignore the busker, a few stop to listen, and some toss money into his violin case.

The very same events depicted in the video are recounted in a magazine article-a Pulitzer-Prize-winning magazine article.

The ordinary (depicted in the video), when examined closely (in the magazine article), enthralls.

This renowned article is "Pearls Before Breakfast" by Gene Weingarten from the Washington Post Magazine. The violinist is musical prodigy Joshua Bell and this piece of narrative journalism was a social experiment to see if one of the "nation's greatest violinists," playing some of "humanity's finest classical music" on one of “the world's greatest violins," would be noticed in a D.C. Metro stop during morning rush hour (Weingarten).

What this example illustrates is the elusive quality magazines possess to capture and intrigue. Most readers of this chapter have likely been engulfed by a magazine before-serendipitously reading one article after the next, or looking with 
extended interest at photos printed on its pages. Why we have this affinity for magazines is difficult to ascertain. At minimum, it involves a combination of social psychology, human biology, and personal circumstance.

To ask why magazines matter is not to presume they don't, but to attempt to address their enigmatic significance to society and to those who read them, the passion of those who create them and, by extension, their value to those who advertise in them. Although complex, this societal valuation of magazines is key to understanding why we should care about their survival.

This chapter reviews why magazines matter from the top down, beginning with their worth to society, then to the individual and, as a result, to advertisers. In the process, this chapter presents certain theories that form the conceptual framework used in the analysis of the four case studies that follow.

It also briefly discusses the more specific issue of the value of printed magazines, and suggests reasons why digital reproductions are not as satisfactory for meeting society's needs.

\section{Why do magazines matter to society?}

"There has always been and will always be reporting so important to the functioning of society that no price tag can be placed on it."

-David Skok, Be The Disruptor, 2012

\section{A Considered Fourth Estate}

Before going further in discussing the business structures of magazines, it is important to outline the social impact magazines offer. 
The ability of magazines to sustain operations is, of course, of great importance to magazine publishers and to those working in the industry, as well as its partners and investors. But, as mentioned, there is an importance to society as well: the role magazines play upholding journalism as the "fourth estate" (Shultz 3). Like newspapers, many magazines hold government to account, inform citizens, and exhibit a traditional journalistic "gatekeeping" function in determining society's priorities (Shoemaker, Vos, and Reese 73).

Journalism's role in democracy, keeping citizenry informed and supporting general public good is often referred to as the social responsibility model of journalism (Mersey 125). Although the social responsibility model is most often applied to newspapers, magazines-in particular independent magazines-are also important purveyors of the free press as well.

As Monocle Magazine publisher Tyler Brûlé (Chapter 9) says of the titles his company's newsstand café carries: "just-launched indies... get shelf space not because they're new and hyped but because they offer journalistic value," (Brûlé 290).

However, the social responsibility model is under threat largely due to technological disruption, with the largest threat being a failure to engage audiences (Mersey 126; de Botton).

In this chapter, the analysis of Alain de Botton explains how magazines address and prevent reader disinterest. The next two chapters review in more detail the technological disruption. 
In his book, The News: A User's Manual, de Botton discusses several issues affecting journalism, with one recurring problem: the apathy society feels towards important news topics. He suggests several solutions, and although he does not specifically suggest magazines are the way to address these problems, we will show that these publications deliver on many of the proposed solutions.

First, de Botton suggests that news speaks to readers with greater clarity when they are open to it, and return to important ideas over time (30). As shown by the Washington Post Magazine example with violinist Joshua Bell, we are more open to experiencing and ingesting considered information when we choose to (e.g., we are not open to listening to a top violinist when it interrupts our morning commute). Similarly:

"Part of the ethos about choosing a magazine, about investing in paper and print...is that there is something about sitting down with a physical copy, and it's not just about the information, it's about the posture you take when you sit down with the information..." (Vargo).

When we pick up a printed magazine, it is in those perfect circumstances for ingesting content. Magazines usually have longer shelf life (monthly, quarterly), sitting on our coffee tables, in waiting rooms, and in our bathrooms, physically reminding us to return to their ideas over time.

Magazines too revisit topics. For example, Mother Jones Magazine has repeatedly devoted cover stories to reports on gun violence ("The True Cost of Gun Violence," "Inside the Race to Stop the Next Mass Shooter," "The NRA's Murder Mysery") and even went so far as to create an award-winning database of mass shootings (Maley). Together with its continued analysis, its efforts have contributed 
to society, helping to inform the national debate around gun control in America (Maley)

In this vein, de Botton suggests that "the news seek ways to nurture greater competence in the future." Instead of bringing down the powerful, he suggests investigative journalism start with a subtly different goal: "the desire to try and improve things" (65).

In addition to the Mother Jones example of trying to improve things, this type of goal is exemplified by independent publications such as The Outpost Magazine, which features narrative journalism about the Arab world that is "forward looking and upholds an optimistic view on a world where possibilities are infinite" (TheOutpost.com) and Tom Tom Magazine (see Chapter 6), which "seek[s] to raise awareness about female percussionists from all over the world and hopes to inspire women and girls of all ages to drum, all while strengthening and building the community of otherwise fragmented female musicians" (TomTomMag.com).

As these examples touch on, (and as will be shown in the next section "Why Magazines Matter To Readers") the magazine acts as a vehicle for social identity, which sometimes involves fighting for distinctiveness from other groups through social action (Tajfel 67).

Lastly, de Botton argues foreign news should humanize the alien by adopting art techniques (86). De Botton points to Landscape with the Fall of Icarus, where the tragedy (Icarus falling to his death after flying too close to the sun) is only noticed by artists and poets.

"[Artists] notice stuff: the small and unobtrusive stuff that other people - 
ploughmen and shepherds, you and me, and journalists in a hurry - miss and yet that is essential to holding our usual indifference and callousness" (109).

De Botton says journalists should "allow travel writers and novelists to impart aspects of their crafts to journalism" (109). He also suggests foreign news correspondents not be so afraid to introduce their personal reactions:

"[Y]et if any harm could conceivably come to the viewer from seeing another country through the distorting lens of the correspondent who expressed candid reactions to it, it is as nothing next to what can be the stifling boredom produced by ostensibly neutral and accurate reporters who, by their implicit denial of even having a response to anything foreign, fatally undermine our desire to add to our knowledge of the world" (99).

While not a novel observation, the call for more context is one magazines have been answering for decades (see more in Chapter 3).

In fact, just in the last decade, there have been many examples of magazine writing that rippled through society. A few notable examples include:

The Washington Post Magazine's Pulitzer-prize winning profile of Gradystein Williams Hutchinson who "by and by changed the way I saw the world" according to author Howell Raines, and gave a new voice to segregation and civil rights (Garlock 440). Joy Gordon's piece “Cool War" published in Harper's Magazine investigating economic sanctions and weapons of mass destruction. Jon Krakauer's "Death of an Innocent: How Christopher McCandless Lost His Way in the Wild" published in Outside Magazine, was later re-worked into the Academy Award-nominated and Golden Globe winning screenplay "Into the Wild" and resulted in many McCandless pilgrimages (some successful and some fatal) to the famed bus where he perished. Michael Lewis' “Wall Street on the Tundra” published in Vanity Fair, April 2009, analyzed under the public eye the collapse of Iceland's economy. Occupy Wall 
Street, was originally organized by independent magazine Adbusters. From the pages of Rolling Stone magazine came Hunter S. Thompson's “Fear and Loathing in Las Vegas" and subsequent "Fear and Loathing on the Campaign Trail."

All touch again on de Botton's calls for reporting that embraces social change, employs artistic minds, and gives personal insight and context to otherwise possibly boring topics.

Many notable exposés came from this last magazine, Rolling Stone. Although a music magazine, the publication plays a larger role in society: "We understood that music was the glue holding a generation together. And through music, ideas were being communicated about personal relationships, social values, political ethics and the way we wanted to conduct our lives," (Love xi).

This role that magazines can play in defining our social identities is considered next.

\section{Why do magazines matter to readers?}

"They matter to readers because it makes them feel a part of a group, not just independent magazines, when you pick it up you feel a part of that group, you

think 'that's $m e$ '... building a brand that's incredibly trustworthy,"

- Dr. Barbara Rowlands, Director of the MA in Magazine Journalism at City University London

Why do we like magazines? More specifically, why do we like printed magazines?

The answers to these questions are as indispensable as they are complex. However, a fundamental understanding of why we like magazines-in particular 
printed magazines-underlies the significance of research around their business models.

This section outlines various identity theories and the role magazines play in how we define and sustain our identities in society. It will then outline why we like printed magazines over similar digital content. This chapter provides some elucidation about why magazines matter as social identifiers. However, due to space constraints, this section can only provide an overview of identity theory as it pertains to our magazine delectation.

For most readers, societal standing is not ascribed but achieved (Linton 115). Ascribed status is one predicted from birth (e.g., royalty), whereas achieved societal standing requires us to define our self-concept both internally (to ourselves) and externally (to society) and to reaffirm this status continuously over time (Tuomi 233). This is done through self-identifying and through inter-individual comparisons, with memberships in social groups contributing largely to the image we have of ourselves and that others have of us (Tafjel 61).

The above ideas come from Social Identity Theory, first developed by Henri Tajfel in the 1970s.

For the sake of completeness, other identity theories in communication studies will be noted, and a brief explanation provided for choosing Tajfel's Social Identity Theory will be given.

\section{Other Identity Theories in Communication Studies}

There exist two similar theories in communication studies. The first is called the Uses and Gratification (UAG) theory, originally a suggestion by Elihu Katz in an 
editor's note in the journal Studies in Public Communication (1959 2-3). Katz' suggestion has since been explored by many scholars, (Payne et al., Palmgreen et al., Blumler) and has even been applied to consumer magazine research (Bonner, Glapka, Duke, Monroe, Jere and Davis, Abrahamson²). Over the years, the number of proposed motivations for why people consume media have expanded and contracted. The most recent list of typologies includes four motivations: (1) diversion (i.e., as an escape from routines or for emotional release), (2) social utility (i.e., to acquire information for conversations), (3) personal identity (i.e., to reinforce attitudes, beliefs, and values), and (4) surveillance (i.e., to learn about one's community, events, and political affairs) (Ruggiero 26).

However, because the types of these motivations stem from our social identity (e.x.,: the diversions we seek, the information we discuss in social conversations, the communities, events, and politics we engage in) Social Identity Theory is better suited for analysis of individuals' motivations for seeking media in the first place.

This second theory is an identity-based model of journalism proposed by Rachel Davis Mersey in "Journalism is Spelled with an 'I"' (2010). Mersey argues against the "gatekeeper" or social responsibility model, saying journalists should listen to their readers and report what is significant to them, instead of deciding for them what news should be of importance:

2 In his study using UAG theory, Abrahamson admits the social function of magazines has been "under-researched" (Abrahamson and Prior-Miller 259-260). 
“Journalists' work should be driven by attracting readers to their products, whether they be print or multimedia, and ultimately getting those readers to connect with the work, its author and one another" (Mersey 17).

Conceptually, the identity-based model of journalism is linked to Social Identity Theory by its focus on attracting readers to media that reflect their interests. However, Mersey's theory focuses narrowly on how content can be tailored to one's interests, and does not consider the wider process of locating oneself within society in the first place and maintaining or adjusting this achieved status. In other words, Mersey's theory asks “Do I like this content?” whereas identity theory asks “Who am I?" Thus, Mersey's identity-based model of journalism is too narrow for this analysis.

Instead, delving deeper into the area of social psychology leads to using primarily the theories of Tajfel and Turner 3 .

\footnotetext{
3 It is surprising Tajfel's and Turner's identity theories are not more widely used in communications research, although it is suspected this is because much of their research was overlooked due to its focus on the social psychology of human groups in conflict (Tajfel 1) and the role individuals' affiliations with their groups played in these tensions (Tajfelx iiv). However, Tajfel himself suggested "in our view, whether modified or not, an approach of the kind represented here will have to be adopted to give social psychologists a reasonable chance of having something meaningful to say about the wider social realities" (Tajfel 1). As such, we take Tajfel's advice, and base our analysis of the role magazines play in our wider social realities through the theories developed by Tajfel and Turner.
} 


\section{Social Identity Theory}

Tajfel's theory uses four linked concepts to discuss how we determine and sustain our identity: social categorization, social identity, social comparison and psychological group distinctiveness (Tajfel 61). Let us review each in brief.

Social categorization is the ordering of a human's social environment to simplify it in a way that makes sense to the individual (Tajfel 63). This concept has a companion theory by John C. Tuner, which states social categorization is a component of the self concept. It suggests "social identity is the sum total of the social identifications used to define him- or herself," and that these social categorizations "state at the same time what a person is and is not" (Turner 18). Social identity is thus our group membership and "that part of the self-concept which derives from his knowledge of his membership of a social group (or groups) together with the value and emotional significance attached to that membership," (Tajfel 63).

Social comparison links social categorization with social identity (Tajfel 64). It purports that "a group becomes a group in the sense of being perceived as having common characteristics or a common fate mainly because other groups are present in the environment" (Tajfel 66-67). In short, it embodies the "us vs. them" idea of social categorization.

Finally, psychological group distinctiveness is the achievement or preservation of perceived intergroup comparisons, such as minority and majority groups, or in-groups and out-groups (Tajfel 76). 
In brief, these systems orient us and help us create and define our place in society (Tajfel 63), and "society not only defines but creates psychological reality," (Berger 106, qtd by Tajfel 64) ${ }^{4}$.

\section{Identity, Digital Networks, and the Physical World}

Since these theories were developed by Tajfel and Turner in the 1970s and '80s, the way we categorize and connect with social groups has changed significantly due to the Internet and mobile communications. These new social networks are often defined by specialized roles people play in the network (Tuomi 230). Although several researchers have discussed identity and community structure in online communities (Smith and Kollock, Wellman), much of the analysis describes them as a new type of community:

"It almost always treats the Internet as an isolated social phenomenon without taking into account how interactions of the Net fit together with other aspects of people's lives. The Net is only one of many ways in which the same people may interact. It is not a separate reality. People bring to their online interactions such baggage as their gender, stage in their life cycle, cultural milieu, socio-economic status, and offline connections with others." (Wellman and Gulia 170).

It is this intersection with the offline that interests us, especially around the

Internet's effect on our non-digital world and how we identify ourselves using

material objects and in physical space (in this case, magazines).

4 Part of how society does this is through news. Similar to the "gatekeeper" theory of journalism, news "as a constructed reality" has been studied by sociologists Hervey Molotch and Marilyn Lester, who break it down into a need to "render otherwise remote happenings observable and meaningful," (Molotch and Lester 101). Although journalism's objective ability to recount happenings is often critiqued (de Botton 11, Harcup and O'Neill), its influence in our perception of reality remains indisputable. 
Researcher Illka Tuomi discusses this relationship of identity, the Internet and the physical world. As Tuomi explains, individuals today connect through roleto-role networks. Due to their ubiquitous fluid nature, these networks see identity management becoming a key activity, requiring an increasing amount of resources, and material products, to maintain our identities in such ever-changing networks:

"Social networks management, communication and identity construction are key activities ...People are not passive consumers, but they actively construct their social and psychological position using material and mental products" (232).

Tuomi echoes a previous point that roles are not ascribed for most of us ("with the exception of perhaps the Queen of England"), but instead achieved, and so we must work to create our identity (233). Tuomi goes on to say we must actively produce this identity not once, but over and over again: "In role-based networks position is rarely defined by where one sits. Position, therefore, is not occupied but constantly produced. Without constant reproduction, positions are easily lost" (233).

What is of particular interest here is the role the physical world has in helping us reproduce our identities. Tuomi also says, "[p]aradoxically, this may mean the importance of location increased, as people try to build coherent identities by grounding them on physical space" (233).

It is accepted that the Internet has created information overload, and in this context produces multiple simultaneous role-to-role networks (Tuomi 232). One answer to the problem of navigating this overload is clustering geographically around people who share similar portfolio of roles (Tuomi 232), which will be discussed further in the case studies. 


\section{Social Identity and Independent Magazines}

This basis for theories of social identity can be applied to magazines.

To achieve societal status, there must first be an understanding of our social reality. Magazines help us define social reality by participating in the gatekeeping/social responsibility functions of journalism, and do so even in the face of declining audience attention due to digital disruption.

Next, magazines help us in categorizing society into groups. These range from different types of magazines, to the content they curate (themed issues, columns within those issues etc...).

It follows that magazines offer groups to identify with. A magazine subscription is very clearly this type of identification. Independent magazines in particular aid in social comparison of groups simply by their independent nature (i.e., you must be independent from something else) (Bennett 1).

This relates to psychological group distinctiveness and the creation of "in groups" and "out groups." "There's a feeling of a club, this is something I think all great magazines do... one of the great strengths is they have this little club that you want to be a part of," (Ben Rylan, Edwards, and Urbonne).

This social categorization of "in groups" and "out groups" is often portrayed as minority and majority groups:

"To be a member of a majority situates an individual automatically inside the group; to be a member of a minority places him outside, either towards the top when it is an elite group, or towards the bottom if his group happens to be oppressed" (Tajfel 256). 
We see this in many independent magazines, which are themselves a type of minority (consumer magazines occupy the majority). Here elite tastes (e.g., Palm Springs Life Magazine, Monocle Magazine) and oppressed groups (e.g., Tom Tom Magazine) form the magazine's readership. As extreme examples, consider minority group publications such as the al-Quada magazine Inspire, and the Japanese mafia magazine Yamaguchi-gumi Shinpo.

Magazines also help continuously redefine our social identity, as required by role-to-role networks. They simplify this complex process by offering physical objects to help build these coherent identities and, as will be shown in the case studies that follow, offer physical nexus for individuals to cluster around people who share similar roles.

In the next section, the importance of magazines' physical existence is reviewed in grater depth.

\section{Why We Like Printed Magazines}

"Once in a while something comes along that changes the way we live. A device so simple and intuitive, using it feels almost familiar." -Ikea promotional video for their 2014 print catalogue (satire of Apple commercial).

"Taught as we are to read and write in early childhood, we hardly realize the place this wondrous double art fills in civilized life, till we see how it strikes the barbarian who has not even a notion that such a thing can be. John Williams, the South Sea Island missionary, tells how once being busy carpentering, and having forgotten his square, he wrote a message for it with a bit of charcoal on a chip, and sent this to his wife by a native chief, who, amazed to find that the chip could talk without a mouth, for long after-wards carried it hung by a string round his neck, and told his wondering countrymen what he saw it do" (Forsythe, Nadal, and Sheehy 167). 
Many of us would admit to keeping magazines around as evidence of the wondrous ways they have spoken to us. It makes sense, as an investment we've made in this type of communication and in our own identity:

"Part of the ethos about choosing a magazine, about investing into paper and print and photography and colour and long-form essays, is that there is something about sitting down with a physical copy, and it's not just about the information but it's about the posture that you take when you sit down with the information, it's about what you're presenting code-located. With a magazine, once you've put it to print, it's there permanently, you've managed to actually put the ideas into someone's living room where someone is going to pick it up, or you've put it in a café where someone is going to encounter it by chance" (Vargo).

This speaks to one human trait that differs homo sapiens from all other animals: the ability to communicate ideas about the future and the past in writing (Tattersall).

Humans have created and agreed on symbols to represent objects and ideas. We use these agreed-upon symbols (language) to communicate things to each other, from warning of danger, to where to find food, to passing on culture such as how to build tools, how to care for animals, how to farm and how to create art (Fagan and Beck). Although other species have shown language capabilities, we are the only ones with the ability to write it down (Tattersall).

Our ability to recount the past in writing is called history (Lavenda and Shultz 30). We prize historical records, preserving them on pedestals within our museums, galleries and universities. These records require no outside machinery to gain the historical information they contain. As long as we have a common understandings about the symbols used (e.g., written language), we can interpret 
what they say. Simply put, we can understand these communications immediately without relying on a secondary, or a tertiary conduit to decode the information.

By comparison, digital information (floppy discs, CDs, USB keys and digital files such as .pdf, .doc, .psd), requires a highly specialized machine and its associated software (and updates) to get the information into a form humans can comprehend. The reality of this distance between readers and the information recorded as history was highlighted in the comments of Google's Vice President, Torrence Boone, at the American Association for the Advancement of Science in 2015. He succinctly advised "If there's a photo you really care about, print it out," (Sample).

Once decoded, there are two layers of interaction involved in the viewing of digital and online information: navigation and the content itself. By contrast, print has only one layer of interaction: the content (Leslie 216).

In addition, it is more difficult to establish a hierarchy online (Leslie 216). Once the content is located, determining where to begin and how to proceed requires additional effort on the part of the reader. This drain on our mental resources may inhibit our comprehension of content (Wästlund, Erik, et al.).

This inherent affinity for print is further supported by how human brains interpret written language as a part of the physical environment (Wolf). The human brain perceives text in its entirety as a physical landscape (Jabr).

The above-mentioned multi-disciplinary studies point to similar conclusions: "When we go online, we enter an environment that promotes cursory reading, hurried and distracted thinking, and superficial learning. Even as the Internet grants 
us easy access to vast amounts of information, it is turning us into shallower thinkers," (Carr 115-116).

These points support the ease physical objects and spaces offer in efforts to define and redefine our identities in complex role-to-role networks as a part of the social categorization portion of creating our social identities.

Lastly, print offers a level of excitement:

"I think the big thing is print is just so difficult. To make something that looks really good and is really effective is just hard work, and the fact that there is a deadline. There's a day it has to be done, it has to be perfect, and it gets printed and delivered to people. And there's just a level of excitement with that, that's much harder to get online," says independent magazine expert, Steve Watson.

It is for these reasons that advertisers continue to find value in the unhurried, undistracted, considered environments of printed magazines.

\section{Why Do Magazines Matter to Advertisers?}

"In an age of distraction, nothing can feel so luxurious as paying attention." -Pico Iyer, The Art of Stillness

As shown by the Washington Post Magazine experiment mentioned at the beginning of this chapter, readers are not open to messages during inconvenient times. Such messages are tuned out-particularly ones wanting our money-no matter how much noise they make.

"By launching a magazine, you'll enter (or create) a rich ecosystem of individuals and organizations that share your passion, as well as a host of brands who will seek to market themselves using your sector as a link between their brand and consumers" (The Publishing Playbook). 
The previous sections of this chapter demonstrate why printed magazines establish a strong link between advertisers and consumers. Printed magazines are spaces that hold a reader's attention. They communicate information clearly without requiring too much additional mental energy or associated distraction. Most important, they play a role in the formation of social identities. They are employed to do that over and over as identities are preserved in complex, changing networks.

The role of magazines as a social category dovetails with lifestyle brandsthose who seek to have their products contribute to the definition of the consumer's way of life. That attempt to market a product or service that embodies a group or a culture is why we see many brands creating their own print publications (e.g., Colors by clothing brand United Colors of Benetton; Porter by online retailer Net-APorter.com; The Red Bulletin by energy drink Red Bull; Arctic Circle Magazine by Canada Goose outerwear company; and Pineapple by online short-term vacation rental site Airbnb).

Yet, these publications lack the social responsibility component of other nonbrand magazines. This gatekeeping function magazines play in constructing reality is key to the process of defining our place in society. As was shown, magazines continue to play a strong social responsibility role, even in the areas where scholars such as Alain de Botton point out the fourth estate falls short: speaking to readers when they are open to it, returning to important ideas over time, nurturing greater competence in the future, trying to improve things, humanizing the foreign by adopting art techniques, and giving personal insight and context to otherwise boring 
topics.

Readers may choose the products of specific brands that advertise in magazines over another product because it makes up a part of social reality, because we identify with it, and because we view it as a part of our "in group". These are the strongest selling points for the majority of brands.

In addition, marketing messages in print have a greater ability to reach customers as research begins to show unhurried focus and greater comprehension when we read print rather than digital screens.

However, despite these reasons why magazines should continue to matter to advertisers, the Internet and mobile devices severely disrupted this revenue stream for magazines (discussed in Chapter 4). As a result, magazines have developed alternative revenue streams, which we explore in the case studies that follow. 


\title{
3. WHY MAGAZINES HAVE THRIVED
}

\author{
"Print changes, but it doesn't go away" \\ - Scott Dadich, qtd. in Jeremy Leslie's The Modern Magazine.
}

Many business models proposed by today's media companies have been tried before. "In fact, pretty much every media business model offered up...has a $19^{\text {th }}$-or early $20^{\text {th }}$-century analogue," writes Justin Fox in The Atlantic, a publication that was itself around to see the changes, as it was founded in 1857 (Mott 6).

During the nineteenth century, social change transformed magazine publishing. Growth in the literate population, improvements in printing and papermaking, reduction of distribution costs, and the emergence of national advertising as a significant source of revenue allowed publishers to adopt a new business model in which advertising sales and subscriptions funded the industry. This model has survived wars, depressions, and technological disruptions ranging from the telephone to radio and television-until now.

The technological disruption caused by the Internet has affected revenue streams and uprooted an industry. How can such a robust model, grounded in 165 years of continuous operation, be in crisis?

This chapter reviews how consumer magazines have adapted their business models in the face of disruptive technologies since the advent of the legacy magazine business model. It will attempt to show that many solutions proposed today were tried before, and that the reigning innovation to see publications through, prior to the most recent digital disruption, has been content. 


\section{The Legacy Model Was Born}

All in all, it was an auspicious birth. The legacy business model for magazines was an innovation of the mid-nineteenth century (Mott 11). A wood-pulp product in the right place and right time, magazines took advantage of favourable socioeconomic conditions, including a reduction in distribution costs, growth in literacy rates, technological innovations to the printing press and the industrial expansion resulting in more consumer goods (Rutherford 170). This nexus point in magazine history occurred in 1850, and ushered advertisements for goods into the households of their prospective customers (Wolseley 5). The industry never looked back.

Advertising costs were by the line based on circulation, but extra advertising revenue was brought in via "reading notices." These were "advertisements passed off as regular reading matter" (Mott 11), and this was the grandfather of today's "native advertising." Shortly after, advertising agencies were organized as an entrepreneurial endeavour in themselves (Mott 12).

Of course, had publishers been paying closer attention, they may have seen the demand for the ad agency and developed their own in-house. This may indeed be a positive litmus test of some of today's magazine revenue innovations, with many independent magazines married to advertising agencies (as we see in Palm Springs Life, Monocle and some brand extensions by The Walrus).

Frank Luther Mott offers a good overview of the first disruption to the model, in his book A History of American Magazines, 1850-1865, saying the "panic year" of 1857 was the first disruption for American magazines (5). It was during this time 
that bank failures as a result of declining investments in railroads and land speculation (Calomiris and Schweikart 809) resulted in unemployment. That in turn affected magazines of the time, with subscribers unable to renew and publishers going bankrupt (Mott 5). Ironically, it was the same technology (rail travel) that created the magazine business model, which may have been the cause of the panic.

Shortly after, the Civil War began in 1861 and supplies and access to printers and paper became unreasonably expensive for many, in addition to conscription interfering with labour (Mott 8). It was a bad time for magazines and newspapers, but much worse for magazines since the increased demand for news kept their counterparts alive (Mott 6).

Only a few magazines survived the war, with such business innovations as reducing their size, temporarily suspending operations, or using a poorer grade of paper. Yet, during this time, the main successful innovations were in the form of content. It may be argued that the modern adage "content is king" rang true as early as the nineteenth century, for magazines and newspapers alike. For example, when the people's press overtook party papers and religious papers in the late nineteenth century, the key innovation was content (Rutherford 176). But it's important to note, these changes to content and even to the size and paper grade, were not changes to the business model. Magazines continued to earn revenue from advertising and subscriptions.

Within the nineteenth century, the legacy business model proved robust, and has since survived many technological disruptions. 


\section{Radio}

The invention of radio was the beginning of a serious threat to periodicals, namely to newspapers, for the opposite reason that the Civil War was a bigger threat to magazines. Newspapers' core business was providing immediate news, and radio's instantaneous and widespread dissemination of news to listeners across far distances threatened a rapid conquest of the paper's principal service (Allen 49). This major technological disruption has parallels to a similar conquest of the Internet over the same service core.

In Gene Allen's analysis of why newspapers first adopted radio broadcasting, we could almost replace the word "radio" with "social media" and it would still apply today: "Their reasons were often promotional, using radio...as an advertising vehicle for their newspapers" (51). Similarly, in the early years of social media, many news organizations viewed social media as simply another way to promote their brand.

Allen describes radio-graphing as an example of " $[\mathrm{t}]$ he notion that radio could 'whet, but not satiate' listeners' appetite for news" (52). This is very much like how social media incites readers to click through to web articles, or how a metered paywall may entice readers to purchase a login to see more articles.

As Allen goes on to explain some of the Canadian Press' early attempts at restrictions, he notes "it was generally agreed that bulletins about major accidents or natural disasters...could not reasonably be withheld" (53). Here, we see similarities to today's practice of lowering paywalls when major news is breaking. For example, the Boston Globe lowered its paywalls when the Boston Marathon 
bombing occurred, and the Seattle Times did the same after the Highway 530 mudslide (Kirkland).

Although specific to newspapers, this again highlights that changes to news dissemination were not so much changes to the legacy business model, but rather introduced new considerations. Although these new considerations around radio reporting were more acute for newspapers, magazines today use metered paywalls, and so the parallel to choosing what content to release via the new medium is a relevant discussion for magazines as well.

However, commercial radio came at a fortuitous time: it was the Roaring Twenties, and the economy was in fine health (Sumner 57). In his account of the American magazines of the 1920s, David E. Sumner outlines how the startup of some of the century's greatest magazines happened during this decade (57-73). Few writings exist on the impact of radio on magazines, although perhaps the favourable economic climate, in addition to magazines being less in the business of disseminating immediate news, acted as a buffer to the disruption imposed by this new technology on the magazine industry versus the newspaper industry.

But complexities due to radio were coming to magazines in the 1930s. Radio advertising actually grew during the Great Depression, decreasing ad revenue for magazines (Sumner 76). Coupled with increased production costs, competition from radio resulted in severe financial problems for magazines (Sumner 76).

With ad revenue declining, magazines had only one revenue leg to stand on: subscriptions. Indeed, circulation increased during this time for magazines, in part due to the socio-economic culture of the time, as Sumner explains: "If Americans 
were out of work, then a magazine subscription remained an affordable means of entertainment and diversion" (72).

Again, as with the content innovations at the turn of the century, content was the successful innovation for periodicals surviving disruption in the 1930s (Sumner 78). It was an era when factual information about the economy was in great demand, consequently, successful magazines that survived the Great Depression emphasized news and factual reporting (Sumner 78).

\section{Moving Pictures}

Movies were actually a positive technology to impact magazines. Growth of movies in the 1930s expanded the public's interest in less factual topics, re-opening popular appeal for leisure topics (Sumner 79). One of the most famous publications to launch at this time was Life magazine, in 1936. This "show-book of the world" (Life magazine's purpose statement qtd. in Sumner 88) was that perfect combination of content: photos, people, their work, and currents events (Sumner 88). This was echoed by Condé Nast, who attributed the success of Life to incorporating "news values" alongside human-interest topics (Condé Nast qtd. in Sumner 91).

However, the Life that launched in 1936 became a casualty of the next technological disruption (television) and closed in 1969 (Sumner 88).

\section{Television}

If movies re-opened the public appetite for entertainment, and Life magazine capitalized on this by merging this shift in tastes with previous desires for factual 
news, television combined the formula to create news as entertainment (Postman 107).

Although some believe television caused the decline of the general interest magazine (Kobak qtd. in Sumner 124), it spurred the rise of special interest magazines (Sumner 124). This adaptation of the magazine industry once again shows a change to content, not the business model framework. It was this approach to content that allowed magazines to survive beyond radio and television. While newspapers, TV and radio all zigged (towards general interest), magazines zagged (towards specialized content). And this differentiation appealed to advertisers, as Sumner says: "Advertisers found that magazines could deliver these targeted audiences better than any of the other three media" (128).

This specialized types of content would continue through the 1960s, thriving off the advent of "New Journalism" and navel-gazing tendencies of the "70s, or "The Me Decade," as coined by New York Magazine writer Tom Wolfe. Wolfe explains it was a time when Americans wanted to escape the world's problems and focus on their own interests "polishing the one's very self” (Wolfe 1; Sumner 157). These were ripe conditions for niche publications to blossom.

There is another reason the likes of radio and television did not affect magazines to the same extent as newspapers: these networks of information were providing a service. Originally telecom and cable companies provided a service platform to all segments of society, which news organizations "hired" to reach their final customers (Sanz et al. 182). 
Magazines, however, never engaged in this type of relationship. The magazine's product was not the dissemination of the latest news, therefore magazines never needed to co-operate with these new technologies to keep their foothold with customers (be they advertisers or readers).

Magazines did, however, co-operate with other technologies to reach their customers, such as paper producers, printers, and distributors. And so when the Internet disrupted these production tools, magazines had to get up and shake hands with their new distribution methods, or die trying. Here is where the real disruption to magazines occurs.

\section{Conclusion}

During each of these technological disruptions, magazine publishers who innovated through the content they published were successful at surviving.

Still, the legacy magazine business model of subscription and advertising was sheltered from the brunt of technological disruption for much of the twentieth century. Unlike newspapers, whose core business is the dissemination of timely news, magazines are not as dependent on the freshness of their content, and so continued to operate without losing significant revenue to new technologies that could disseminate news reports with increasing speed. In fact, in many cases, the new technology acted like a barometer, indicating where society's new interests lie, and magazine publishers who paid attention to these shifting values and interests, were thus able to pivot and innovate in their content to appeal to readers of each new era. 
In fact, at nearly every technological disruption, a magazine was right there reporting on it with success. There were telephone niche magazines in the early 1900s (Electrical Engineer), movie-fan magazines in the 1930s (Motion Picture Magazine, Film Fun, Movie Story Magazine); television magazines in the 1950s (TV Guide and National Inquirer reported on TV celebrities); and magazines around new technologies of today (PC World, Wired). No matter the technology, enthusiasts of these new technologies still look to magazines to inform them about their new media passions.

It wasn't until the advent of the Internet that a technology was able to disrupt print magazine's long-standing legacy model. With an astounding number of "innovations" within the print industry re-appearing from historical technological disruptions (native advertising, paywalls, ad agency work), there is only one that has proven successful throughout the decades: content.

However, as will be shown in the following chapter, "content" in the Internet era has not been enough to float all boats in the magazine industry against a rising tide of digital content. 


\section{THE BUSINESS PROBLEM}

\section{Along Came the Internet}

Many describe "print media on its deathbed ever since the birth of the Internet" (Smith). However, as author Benjamine Compaine points out: "Three times in this century the magazine was viewed as a dying institution," (and this sentence was written in the 1980s) (Compaine viii).

Publishers have tried to innovate their way out of difficult spots, but as shown in the previous chapter, the history of technological disruption is littered with similar solutions as those being proposed today (Fox).

Unlike the previous century, this time relying on content will not be enough. With digital native publishers such as BuzzFeed, Vice, and The Huffington Post opening regional offices (Krashinsky), hiring investigative reporting teams (Adams), and looting talent from legacy titles (Sweney), readers are swimming in a worldwide-web of comparable content.

As Tyler Brûlé, creator of Wallpaper* Magazine, editor of Monocle and owner of creative agency Winkreative notes: “Content—don't you hate it? It's the new cword. Once upon a time, content would have been shorthand for editorial. Now it's just filler" (“Monocle's Tyler Brûlé: “I Don”t Care About Social Media and iPads””).

Advertisers moved away from print and invested instead in digital media. Many publishers tried to capture some of those digital marketing dollars by shifting their products online, but digital ad revenue has proven less lucrative than print ad sales and is not filling the losses from print (Sebastian). 
A 2012 study from the Pew Research Centre's Project for Excellence in Journalism found for every $\$ 1$ gained in digital (including digital subscriptions as well as online advertising), \$7 were lost in print revenue (Jurkowitz and Rosenstiel 1). Although this study focused on newspapers in the United States, it's a trend mirrored by magazines, with another Pew report stating: "For print magazines, the number of ad pages sold across the industry overall was down in 2013 (4.1 per cent), after a steep decline in 2012 (8.2 per cent)" (Mitchell et al. 10). These numbers have led the industry generally to accept online ads as a failed revenue experiment (“Where Next for Magazines? Top Publishers Envision Their Future Business Models | the Drum").

With a product that has since its inception been priced very low and subsidized by advertisements, the inability to raise advertising dollars in the new online environment is a big problem. Print sales still dominate the industry, with subscriptions (including digital replicas) up only slightly: "Replicas account for just $3 \%$ of the total magazine circulation," says the most recent Pew study, containing data on the overall magazine industry (Sasseen, Matsa, and Mitchell). With readers unaccustomed to paying for content online, the last traditional source of revenue for magazines is single copy sales. Unfortunately, newsstand sales have also been declining, with single copies dropping 8 per cent in 2012-"about the same rate as the last two years," (Sasseen, Matsa, and Mitchell).

And so, content has never been so plentiful and (due to this high supply), price has never been so low (virtually free). 


\section{Searching for a Solution}

What have large magazine publishers attempted as solutions to the disruptions caused by the Internet and mobile devices?

In such a competitive environment, magazine publishers started asking themselves: How do our digital competitors do it?

One of the largest new media giants is BuzzFeed (Alpert), who keeps most of its financials under tight wraps. However, the company admitted in 2014 on Bloomberg TV that 100 per cent of its revenue comes from branded content (Bloomberg).

In a similar fashion to when established consumer magazines copied the content and pricing strategies of competitor special-interest magazines in the 1970s, legacy publications are copying the digital publisher and trying their hand at branded content.

Time Inc. CEO Joe Ripp went so far as to describe its publication as being in the "content industry" and not in "the magazine industry anymore" ("Time CEO Ripp: We're Not Just a Magazine Company").

Atlantic Media is also experimenting with branded content. However, The Atlantic "got ahead of" itself in its enthusiasm for innovation in digital advertising (Raabe). After running a sponsored story by the Church of Scientology headlined "David Miscavige Leads Scientology to Milestone Year," the magazine removed the piece of sponsored content and issued an apology, saying:

"We screwed up. It shouldn't have taken a wave of constructive criticismbut it has - to alert us that we've made a mistake, possibly several mistakes. We now realize that as we explored new forms of digital advertising, we 
failed to update the policies that must govern the decisions we make along the way," (Moos).

Atlantic Media is also involved in native digital publishing. The New York Times reported that in 2012 Atlantic Media brought in 65 per cent of its ad revenue from this type of new digital advertising (Carr). This includes its digital-only publication Quartz, launched in 2012 (Carr). After seeing huge losses in print (reportedly $\$ 100$ million over 10 years), Atlantic Media owner David Bradley explained the company was experimenting with digital-only, saying "digital trumps print, and that pure digital, without any legacy costs, massively trumps print," (Carr).

North American magazine publisher Hearst lays claim to the most digital subscribers (1 million in 2013). Like Atlantic Media, Hearst is betting on digital-only, but is also trying to re-distribute more costs to the reader. By pricing digital-only subscriptions 30 per cent higher than print, and by pricing dual subscriptions (print and web) higher to show dual value, the company is anticipating that profits will increase "markedly" as readers cross-over to digital and the print product is phased out (Doctor).

However, its paid digital subscribers accounted for only 3 to 4 per cent of total print circulation (Doctor). Although Hearst sells advertisements in its digital editions, these ads are sold in bundles at the whole rate base, which is mainly for print and, at no extra cost, includes the digital editions (Doctor).

Thus, even for the magazine publisher that's leading the pack in acquiring digital subscribers, print continues to drive its business. 
Newsweek jumped in with both feet, going purely digital in 2010 (Sasseen, Matsa, and Mitchell 1). But, just four years later, the newsmagazine decided to relaunch its weekly print edition (Haughney). Although this appears to support claims about the futility of print magazines moving purely to digital ("Magazines Boomed During 2014"), more print publications have decided to attempt this move, most recently Penthouse and The Independent ("Penthouse to Shutter Print Magazine, Go Digital"); (Sweney). It waits to be seen if the pulp for pixels swap will be sustainable. Further indication of the trend that digital may not be the "big" solution, are the number of digital-native publications going to print, such as Betty Magazine, It's Nice That, Politico Magazine, Allrecipes Magazine, and Pitchfork, to name a few.

Pitchfork in particular is an interesting digital-native publication that has moved to print. Cited as a contributor to the demise of the printed music press (Cardew), Pitchfork went from website, to weekly e-reader edition, to quarterly printed magazine. When asked why the Pitchfork website decided to print a magazine, editor Brandon Stosuy explains: “[I]t's just such a different form that lends itself to other kinds of writing and expression, and so we decided to go for it. I see it as an expansion of the site; something that compliments, but also extends it," (Siddall).

No doubt, this different form lends itself to other kinds of advertising too. And it's that kind of brand extension that seems to be working-for both digital and print natives.

In an article about Pitchfork's switch, journalist Ben Cardew notes: “[T]he ensuing rarity of print has...made the physical form all the more unique and worth 
copying. There's something about just sitting with the magazine that feels a little bit more special than it did five or 10 years ago, like you were treating yourself" (Cardew).

As mentioned in Chapter 2, the intrinsic value of print is confirmed by an increasing number of studies ("Why Digital Natives Prefer Reading in Print. Yes, You Read That Right.;" Robb; Zickuhr and Rainie). The ubiquity, immediacy, and thriftiness of the Internet, has gifted to the magazine industry a whole new value: rarity.

The next section explores how this rarity, combined with the jobs print magazines perform for their readers, creates advantages that can be defended and even extended into new revenue streams.

\section{Innovative Disruption \& The Magazine Advantage}

"[W]ithout sales and marketing, strategy, leadership and, first and foremost, revenues, there is no editorial independence left to root for."

- David Skok, Be The Disruptor

Before exploring how magazines are surviving the technological disruption caused by the Internet and mobile devices, this study must answer: What makes an innovation "disruptive?"

In his book The Innovator's Manifesto, author Michael Raynor explains disruptive innovations stem from technological or business advantages that can scale as disruptive businesses move upmarket (Raynor). 
From here, Maxwell Wessel and Raynor's close peer, Clayton M. Christensen, build on the theory of disruption with the concept of the "extendable core" (Wessel and Christensen).

The extendable core is described by the authors as "the aspect of [a disrupter's] business model that allows the disrupter to maintain its performance advantage as it creeps upmarket in search of more and more customers" (Wessel and Christensen).

The authors point out legacy businesses will struggle to keep customers the only way they know how to compete: dropping prices and offering comparable product features (Wessel and Christensen). This strategy is at play very clearly in major magazines: Magazines offer their content in digital formats and online for free (a comparable product feature), and drop prices via regular subscription deals. For example, where data in a 2014 Pew report show subscriptions remaining flat over the years, the report explains "these are normally kept from declining through discounts or special offers," (Mitchell et al.).

Digital-native content producers established a foothold at the low end and moved up market, eating away at the customer base of legacy businesses:

“Once established at the market's low end, the disruptors—by producing low-cost, personalized and, increasingly, original content-move into the space previously held by incumbents," (Christensen and Skok).

Their advantages lie in distribution, search, and reciprocal conversation aspects without being burdened by the expensive overheads of printing a product. Paired with mobile devices, online content providers can deliver all of these 
functions to a large audience almost anywhere. Paired with social media, they are able to deliver content and conversations in an even more instantaneous, customized, anywhere, anytime, manner. Beginning with low-end customers, they then took a foothold, and extended it upmarket while keeping costs low.

Although the disrupter's advantage stems from this extendable core, "not all the advantages of a disrupter's extendable core are so overpowering; often they are offset by disadvantages" (Wessell and Christensen 59). Now, for the most part, the advantages of online publishers are overpowering, however, disruption is a process (Christensen, Raynor, and McDonald), and sometimes it occurs slowly and incompletely in part due to those disadvantages (Wessell and Christensen 58), allowing time for legacy businesses to find new revenue sources.

In the case of online publishers, there is a disadvantage caused by the low barriers to entry. There are far more digital content providers, devaluing their very product, and creating fierce competition for customer/reader loyalty. In addition, since these new technologies are gaining their advantages via technology services, (i.e., the platforms that deliver their content and the algorithms that allow content to be searched, "trend," or to hit that online gold mine to go "viral") (Poell and van Dijck), they are always changing. Here lies another disadvantage. This rapid change in technology means readers' consumption patterns change too, making it increasingly more difficult (and often costly) to keep the crosshairs on a moving target market ("Implications of Digital Device Fragmentation”).

Magazines, however, have a brand built on a century-old product,. As a result of their services not being in constant flux, behaviour patterns are fixed and 
products perfected to a high quality standard. This is just one advantage of print publications. By discerning and evaluating these relative advantages of the business being disrupted, the authors argue legacy businesses can gain a clear picture of what advantages they can defend (Christensen and Skok).

Ask disruption experts where advantage matters, and they will reply: Where it allows people to complete some job that crops up in their lives (Wessel and Christensen).

The jobs-to-be-done lens is a tool Christensen and his colleagues suggest legacy businesses use to identify their advantages relative to their disruptors' (Christen and Skok 10; Christensen and Wessell 60):

“The basic idea is that people don't go around looking for products to buy. Instead, they take life as it comes and when they encounter a problem, they look for a solution-and at that point, they'll hire a product or service." (Christensen and Skok 8).

In the case of print magazines, the overarching job they perform is as a social identity vehicle. Within this are sub-jobs relating to performing this main identitydefining job, as per the social identity theory discussed in Chapter 2. These sub-jobs include: defining social reality, categorizing society, creating groups to identify with as well as offering physical objects and spaces to re-affirm achieved social positions.

Thus, we introduce the jobs-to-be-done theory to complement the social identity theory from Chapter 2. Together, these form the conceptual frameworks used to analyze the case studies to follow. For the purpose of this thesis, this framework is called the Social Identity Jobs-to-be-done (SIJ) theory.

In the next section, these advantages held by print magazines are briefly discussed in light of SIJ theory. 


\section{Identifying Advantages}

\section{Magazines Advantages}

As mentioned, although the Internet, mobile and social media have digitized many core services of print publications, these services have a low-barrier to entry. So magazines are able to do all of these things too through their own online channels in addition to creating, publishing and distributing a printed product 5 .

Although the cost for creating a print product is high, it is this flagship print product that gives magazines their advantage. Magazines perform the job of helping readers define their social identity, and as noted in Chapter 2, offline products matter for this job.

What gives printed magazines an advantage here is not only the barriers to entry around the high costs of creating a print product, or the market share these legacy publications have in this space. It is the greater ability for print magazines to fulfill their customers' social identity jobs-to-be-done.

For example, let's say you recently retired from your job in Denver and you move to Palm Springs, California. You've always loved mid-century modern architecture, and although you can't afford a mid-mod house, you enjoy furnishing your small condominium with pieces inspired by that era. You enjoyed living in Denver, but your bad knee no longer allows you to ski, and so you are getting into golf, and look forward to the warmth of the Sonoran desert and its associated desert

\footnotetext{
${ }^{5}$ However, keeping up with the latest technology can be a strain on resources when you also have to print a magazine.
} 
lifestyle.

The job you need done is to define your new social identify as a resident of Palm Springs. You may notice and pick up a copy of a free Desert Living publication on the street (see more in Chapter 7), and later at the drugstore you see a copy of Palm Springs Life (PSL). On the cover are headlines promising an insider tour of the largest home designed by mid-century modern architect E. Stewart Williams, the latest information on the new golf course that just opened and updates around the upcoming Palm Springs Life Festival. These elements complete the sub-job of defining social reality.

Although you also go online and read about desert lifestyle from various sources, you are very busy moving and setting up your new home, expecting company that week, and this physical print product offers a one-stop shop of what's important and what's not for a Palm Springs resident (defining reality). Plus, you can bring it to the pool and leave it on your coffee table for neighbours to see you are not such a newcomer. This fulfills the sub-job of identifying with the in group ${ }^{6}$, and using a material object to easily establish this identity to others.

You read about the events going on in town, and next month, you attend the Palm Springs Life Festival. This fulfills the sub-job of re-defining your achieved position in society by attending an event that allows you to cluster around people who share similar social identities.

6 These "in-group" identities may be factual, but they may also be aspirational, which is often the case with magazines. 
"Successful companies understand the jobs that arise in people's lives and develop products that do the jobs perfectly. And if a company does this, customers will instinctively 'pull' the product into their lives whenever that job arises," (Christensen and Skok 11)

As shown by the PSL example (more in Chapter 7), the print magazine and its extensions (events and free inserts) are products that allow customers to complete the job of defining (and re-defining) their achieved social identity. This identity is not just a senior citizen who likes architecture and golfing, but many more: social combinations include the LGBT community, the middle-upper class, fashion lovers, pet owners, engaged and newlyweds, and those who identify with the desert lifestyle.

Thus, readers seek the printed magazine to complete the job of role identifier, which also includes sub-jobs as per social identity theory states is required to complete this overarching job. Magazines are a physical object of increasing perceived value that help readers categorize society, define reality, identify with certain groups, and re-affirm their social position to their peers and to out groups.

As mentioned before, the rarity of printed magazines—a phenomenon being caused by the Internet—gives them even more brand power, less competition, and intrinsically higher value for the same product: content. Here is where the advantage matters. Magazines are a highly specialized product that both publishers and readers can trust not to change very much. Not only is this job they perform 
where their advantage lies (and persists), it's also one they can expand on to find new revenue sources.

\section{Creating Additional Value}

As Christensen and Skok point out "new opportunities can become apparent when managers change their perspective about a news organization's role and its standing in the community," (16).

When magazines understand their role defining society and social identities, they can create additional value by extending their trusted and valuable brand to create new revenue streams.

Some examples of extensions include Internet radio (Monocle), books (The Walrus), merchandise (Monocle), courses (Tom Tom Magazine), awards (Tom Tom Magazine), and more to be discussed in the individual case studies.

Two examples of extensions that Christensen and Skok touch on regarding legacy news organizations, which were also noticed in the magazine case studies, are events and consulting work (16). Regarding consulting work, as more companies and marketers recognize the power of print, they too are creating printed products, and looking to magazine storytelling and print producing experts for help, resulting in magazines acting formally and informally as creative agencies (such as Monocle's sister company, branding and design agency Winkreative).

However, some critics warn that as traditional ad agencies step up their game fearing their own obsolescence, the content marketing provided by publishers will face more competition (Doctor). However, as will be shown Chapter 7, Palm 
Springs Life has been doing this type of consulting work successfully for years, even before the digital disruption hit.

Digital content providers are still better positioned than legacy magazines to deliver instant gratification, for very low prices but traditional magazines are better able to deliver on the "job requirement" of identity, precisely because they are grounded in a printed flagship product.

\section{Conclusion}

Although the exact business model for magazines emerging from this latest technological disruption remains unclear, there are some clues.

From a review of historical disruptions to the magazine legacy model (Chapter 3), content has shown to save the day. But as discussed in this chapter, content is powerless in the face of the latest disruption, in large part because the Internet has created a content avalanche.

By using Christensen and his colleagues' notions of the "extendable core" and "jobs-to-be-done" theories, legacy businesses can identify where advantages and disadvantages lie for their disruptors (in this case, digital-native content producers), meanwhile identifying their own relative advantages to defend and extend.

The printed product is the advantage that matters for magazines. Interestingly, the same disruption that lowered barriers to entry for content producers in the online space, has created rarity, and increased value, for legacy content producers in print. 
Here is where the advantage for print magazines exists and creates new revenue opportunities that will be explored further in the case studies of Tom Tom Magazine, Palm Springs Life, The Walrus, and Monocle. Using the Social Identity Jobsto-be-done theory, it will be shown these independent publications have sucessfully determined which brand extensions to pursue in defending against disruptors. 


\section{EXTERNAL ECONOMIC CONTEXT}

\section{External Context (Macro)}

\section{Economic Environment}

Advertising still remains the largest revenue source for the magazine industry. However, ad revenue has not returned to previous levels since the 2008 recession (Publishers Information Bureau).

Print ad sales are further impeded by advertisers moving to digital. As a result, publishers are trying to re-capture that revenue by shifting their products online. However, as previously mentioned, digital ad revenue has proven less lucrative than expected, with digital advertising not filling the losses incurred from print, (Jurkowitz and Rosenstiel; Sebastian).

Although technological innovations commonly spearhead changes in the business world, the rapid technological changes affecting the magazine industry (publication, distribution, and consumption of magazine articles) have created a macro environment that is in a rapid and perpetual state of change.

This continuous evolution has, in turn, induced shifting reader habits ("Implications of Digital Device Fragmentation"). Without any one device leading the pack, publishers must spread their resources thinly to create products for wherever their customers are: on tablets, smartphones, desktops, android, iOS, print, social media, or the next innovation around the corner in a high-speed conveyor belt of technological change. 


\section{Economic Forecast}

The overall economic forecast for magazines appears stable, but within that there is a mix of positive and negative data.

Price Waterhouse Cooper projects magazine revenue, driven by digital, should have returned to growth in 2015 (Global Entertainment and Media Outlook 2009-2018).

It should be noted, however, this same projection was made for 2016 (Global Entertainment and Media Outlook 2016-2019, PwC, Informa Telecoms \& Media).

Although digital consumer magazine circulation revenue will see rapid growth as publishers move away from free content online to paid-for digital editions, digital circulation will still not offset the continuing decline in print circulation (Global Entertainment and Media Outlook 2014-2018, PwC, Informa Telecoms \& Media.).

Digital growth is not the only revenue option on the table. At the Digital Innovators' Summit in Berlin, 2014, Frank Anton, vice chairman of American media company Hanley Wood, suggested better profitability existed for magazines that "expand their traditional role and become more akin to a thoroughly modern marketing agency" ("Where Next for Magazines? Top Publishers Envision Their Future Business Models | the Drum").

However, as discussed in the previous chapter, some critics warn that traditional ad agencies will defend their market share (Doctor), and so any new activities should not be viewed as a long-term revenue source. 
In addition, there is a documented independent magazine "renaissance" gaining popular attention (Marshall; Mettler) that could help the overall magazine market. In Canada, the numbers of magazines has grown since 2001, with accelerated increases in new launches since 2010 (Fact Book 2015 9).

Similar trends can be seen in the United States and the United Kingdom. For example, in the US, 234 new print magazines were launched in 2014, up 21 per cent from 20137, but with fewer launches coming from big publishers ("Magazines Boomed During 2014").

In the UK, new magazine launches were also up, from 210 in 2010 to 285 in 2015 ("Magazine Market Data"). Although this trend in the UK does not elucidate whether these new magazines are necessarily from independent publishers, the author's qualitative observations indicate the UK has a growing independent magazine culture ${ }^{8}$.

For example, there exists the Bristol Independent Publishers-a group of independent publishers who run their magazines out of Bristol, UK. London hosts the largest annual independent magazine conference in the world. There are also many independent magazine shops in the UK, and several independent magazine

\footnotetext{
${ }^{7}$ Data for USA comes from Dr. Sunir Husni, director of the Magazine Innovation Center at the University of Mississippi, who has been tracking monthly magazine launches for US magazines since 1984 (Husni; “Magazines Boomed During 2014") 8 The author travelled to London, UK in October 2015 for this research. She attended the Modern Magazine Conference, interviewed several independent magazine specialists, and visited many indie magazine shops. "There are definitely more magazines now than seven years ago," said Steve Watson in an interview with the author (Watson). Although the UK has a growing independent magazine culture, it should be noted many independent publications in the UK are art or hobby projects and are not considered in this research due to their lack of a business model.
} 
experts hail from the UK. Examples of the latter include Jeremy Leslie who has penned two books on the subject of independent magazines and runs the Modern Magazine conference, Steve Watson founding owner of international independent magazine distributor The Stack and Barbara Rowlands, Director of the MA in Magazine Journalism at City University London.

\section{Economic Differences (Canada, USA, UK)}

As this research reviews independent magazines in Canada, the USA and one based in the UK, it is important to note a few key differences between the economic landscape for magazines in each of these regions.

\section{Canada}

Canadian magazine publishers have access to federal government support through the Canada Periodical Fund (CPF). The CPF is administered by the Department of Canadian Heritage (DCH), and offers funding to eligible magazine publishers for content creation, distribution, online activities, and business development. It also provides support for business innovation projects (this will be discussed further) and collective measures that help to build the Canadian magazine sector.

In addition, independent magazine publishers in Ontario ${ }^{9}$ have access to public funding through the Ontario Media Development Corporation (OMDC) Magazine

\footnotetext{
${ }^{9}$ Ontario funding is mentioned as it relates to the macro environment of the Canadian magazine reviewed in this research, The Walrus.
} 
Fund. Magazine publishers that create 90 per cent or more of an online magazine can also access the Ontario Interactive Digital Media Tax Credit.

The Ontario Arts Council also provides financial support to eligible Ontariobased art and literary magazine publishers through its Periodicals Program ${ }^{10}$.

Due to its population, Canada has a much smaller advertising market than the US and UK.

\section{USA}

Publications in the US do not have access to any state or federal funding. However, they do have greater access to capital, in part due to the country's more liberal investment culture "where startups with a great idea on the back of a napkin can secure VC funding" (as opposed to Canada's "collective conservatism") ("What Entrepreneurs Need to Succeed in Canada"); and also thanks to the high number of high-net-worth individuals (HNWI) in the US (World Wealth Report 2015).

The population of the US is of course much higher than Canada or the UK, although, with more people comes more competition. Nevertheless, this provides a larger subscription base, and accompanying that, a larger advertising market.

\section{UK}

Similar to the US, there is no government funding for periodicals in the UK ${ }^{11}$. However, also akin to the US, the UK is one of the top five HNWI populations (World

\footnotetext{
10 Eligible publishers must be significantly devoted to Canadian fiction, poetry and/or critical commentary on Canadian contemporary arts, culture and society.
} 
Wealth Report 2015). Despite this, a smaller advertising market may result in less investment in publishing businesses ("Where Are the U.K. Publishing Startups? Digiday").

There's also more competition due to the UK's more crowded media market (Digital News Report 2015).

Another difference between UK and North American magazine business is the former's emphasis on newsstands:

“We're newsstand based, we don't have this history of subscriptions, if you have subscribers it gives you a lot of money up front...but magazines on the whole compete on the newsstand, so they're very competitive," (Rowlands).

\section{Opportunities and Threats}

As a part of a SWOT analysis (strengths, weaknesses, opportunities and threats), the external components (opportunities and threats) are discussed below, while internal components (strengths and weaknesses) are discussed in each magazine's respective case study.

Opportunities exist in the areas of expanding traditional roles, the independent magazine "renaissance," the increasing rarity and perceived value of print as a result of the digital content expansion, and government funding for innovation in Canada.

11 Many different types of government assistance are available for start-ups and small businesses; however, of the UK Government's available funding schemes, only one exists for magazines, and it is specific to Northern Ireland ("Publications Grant Scheme - Northern Ireland"). Source: https://www.gov.uk/business-financesupport-finder/ 
In addition, marketing campaigns for magazines are on the rise, such as the Magazines Canada campaign in the form of "movie poster" print ads and online videos promoting reading magazines (Anything Can Happen at a Magazine Stand). In the USA, the Association of Magazine Media ran a three-part series on the power of print in Adweek (MPA).

The Canadian Periodical Fund, managed by Heritage Canada, also introduced in 2013 a new arm of the fund: the "Business Innovation" (BI) component. It supports small and mid-sized magazine publishers encouraging innovation to adapt to changing market conditions ("Canada Periodical Fund (CPF) - Business Innovation Applicant's Guide, 2014-2015").

Threats exist to the magazine publishing industry in several areas. They include increasing costs for paper and distribution ${ }^{12}$, increases to periodical mailing costs (Canada Post Corporation 2014 Annual Report; Mail Classification Schedule 2015; "Publishing Mail Rate Card") and closures of magazine points of sale ("What the Latest USPS Rate Hike Means for Magazines - Folio;" "Indie Bookstores Fill Void Left by Borders;" Bosman). There is though a slight increase in independent bookstores in the USA and the UK (Rosen; Heyman).

\section{Conclusion}

External analysis from a business perspective shows a relatively unattractive market, with forecasts reporting only moderate growth for 2016. Although rapid

\footnotetext{
${ }^{12}$ As shown by a decreasing Producer Price Index (PPI) over the last three years of available data in each nation. Sources: Statistics Canada, CANSIM, tables 329-0056 and 329-0058, and Catalogue no. 62-011-X; Office for National Statistics Table B; U.S. Bureau of Labor Statistics PPI Detailed Report Table 9.
} 
growth is predicted for digital revenue into 2019, the digital sphere is itself changing rapidly and consumer behaviour habits are difficult to extrapolate years into the future. Even accepting rapid digital growth, overall circulation revenue is expected to decline over the next three years, which will have negative effects on advertising.

Although the external analysis of the overall magazine industry is not favourable, examining business structures on an individual level confirms that independent magazines have promise as they find new ways to leverage their strengths and minimize weaknesses. 


\section{CASE STUDY 1 (NICHE) TOM TOM MAGAZINE}

\section{Introduction}

Tom Tom Magazine is a quarterly printed magazine about female percussionists. Its headquarters are in New York City, NY. Although a niche publication, this magazine displays a panoply of products and exemplifies facets of business models observed in the other case studies.

Business elements include a website, social media community, drumming school, events, museum installations, an online shop, post-secondary discussion panels, and drumming competitions. Tom Tom is also an in-flight magazine and is distributed in boutique hotels.

The magazine's business strategy is centred around its mission: to raise awareness about female percussionists, to inspire women and girls of all ages to drum, to build and strengthen the community of female musicians globally and to provide role models in the media that help create an equal opportunity landscape for female percussionists.

Founder, publisher and editor-in-chief, Mindy Seegal Abovitz doesn't credit the majority of her magazine's extensions to strategy, but instead to a "do-or-die" attitude grounded in supporting the magazine's mission. Abovitz also credits part of its ability to grow ${ }^{13}$ to how social media has allowed it to connect with more female

13 Growth over the last five years can be seen through an increase in subscribers (circulation 80,000 in 2016 up from 12,000 in 2011; Twitter 6,066 followers in 
drummers, and the rapid growth of social media at the time of the magazine's launch. Thus, Tom Tom has generated new revenue streams from ventures that support its mission, and hopes to extend further into retail and consulting work. Despite its varied sources of revenue, Tom Tom's main source of income is still advertising.

The magazine also distinctly fulfills the “jobs-to-be-done” (from Christensen's theory discussed in Chapter 4) of any reader looking to identify as a female musician, particularly a female drummer.

Although the magazine is operated by a for-profit company, it exhibits aspects of a non-profit, through its social mission and team of volunteers. Tom Tom's founding editor, Mindy Abovitz, chose the for-profit model purposefully, but it does preclude the magazine from most grants and other funding.

\section{Background}

Mindy Seegal Abovitz, founded Tom Tom Magazine in 2009. It is the only magazine in the world that is dedicated to female drummers. Beyond the print version, it is also a self-described movement, both online and off. Tom Tom "seeks to raise awareness about female percussionists from all over the world in hopes to inspire women and girls of all ages to drum. We intend to strengthen and build the

2016 up from 2,500 in 2011; Facebook likes 12,289 in 2016 up from 8,750 in 2011), increase in print advertisers (issue 24: 1 back cover, 7 full page; up from issue 4: 0 back cover, 2 full page), increase in total page count (54 pages issue 4; 64 pages issue 9; 74 pages issue 23 and 24), and a higher quality of paper used, as well as statements from the publisher herself in the Editor's Letter of Summer 2016 issue announcing further global expansion (Abovitz 2). 
fragmented community of female musicians globally and provide the music industry and the media with role models to create an equal opportunity landscape for any musician. We cover dummers of all ages, races, styles, skill levels, abilities, sexualities, creeds, class, sizes and notoriety. Tom Tom is more than just a magazine; it's a movement," (Tom Tom Magazine mission statement).

Figure 6.0: Tom Tom Magazine, Issue 04, Fall 2010

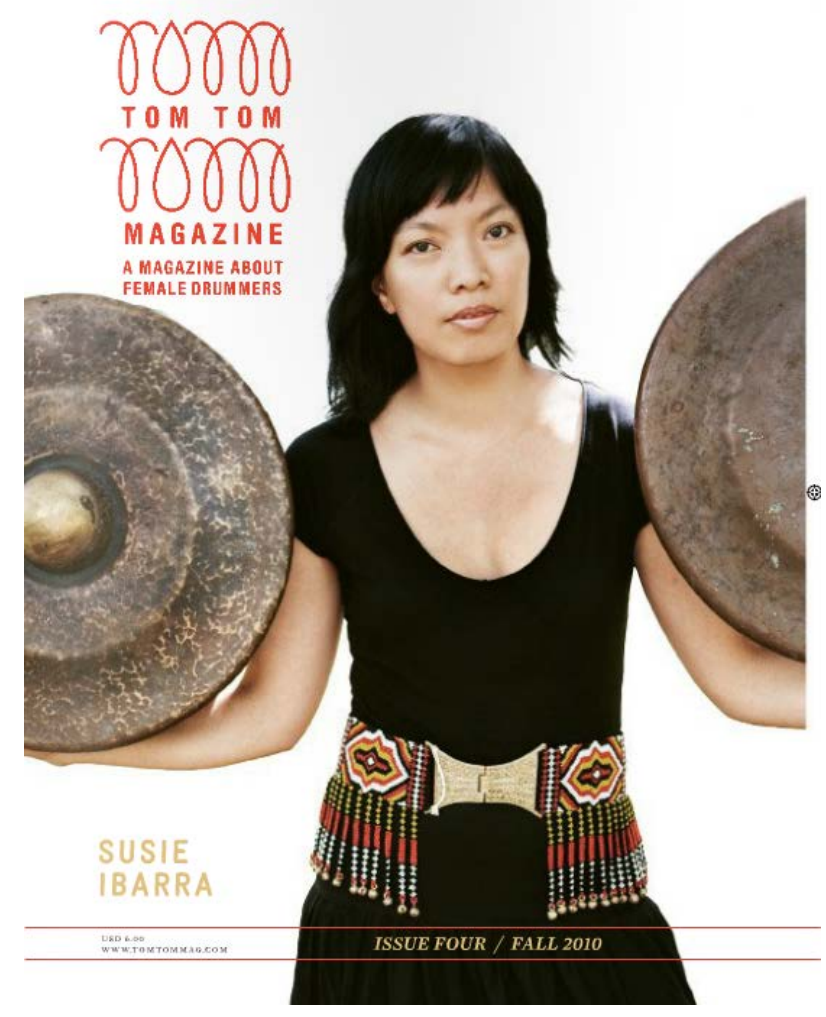




\section{Figure 6.1: Tom Tom Magazine, Issue 24, Winter 2015/2016}

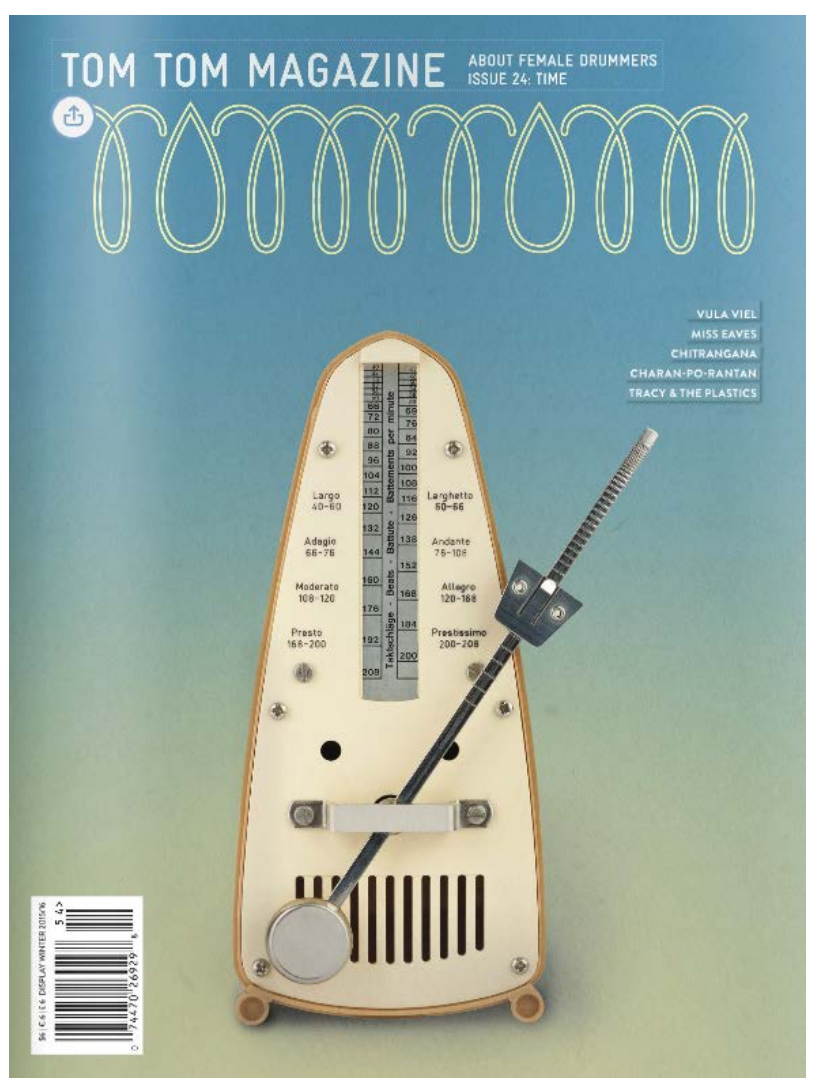

Tom Tom Magazine is distributed across the United States, as well as in Europe, Australia, South America and Japan. It has many international subscribers and readers, both male and female. In the U.S. Tom Tom Magazine is distributed by the leading music store chain Guitar Center, as well as the bookstore Barnes and Noble. It is also distributed by many independent bookstores, such as the bookstore at contemporary art institute MoMA PS1. Somewhat uniquely, it is also available aboard Virgin Atlantic flights in the Upper Class cabins, and in the rooms of Ace Hotels.

With a full-time staff of seven, Tom Tom also has many volunteers, who serve as writers, photographers, and junior designers, as well as helping to distribute the magazine. 
A one-year subscription to the magazine is US $\$ 29.99$. Single copies are US $\$ 6, £ 6$ or $€ 6$.

Tom Tom Magazine's circulation is approximately 80,000 (print and digital $^{14}$ ), with a readership of approximately 250,000 across all platforms. The magazine's website is not behind a paywall, however not all content published in the print edition is available on its website, and vice versa. Although the e-reader version of the print issue is free, it is released after the print issue. Tom Tom has many alternative revenue streams beyond advertising, subscriptions and single copy sales. Below is a list of these activities in brief; these will be discussed further under "Brand Extensions."

Drum academy

Online shop, selling the magazine as well as drums, synth machines, drumming accessories, clothing, art, books, jewelry, CDs, vinyl records and more.

Parties (i.e., SXSW Festival and Conference, Coachella Valley Music and Arts Festival, and launch parties). Some have even caught the ear of notable media, for example being reported in Vanity Fair (Becque) and the New York Times (Wu).

Panels and lectures (at universities, colleges, and commercial venues such as the Apple Store) in the U.S. and U.K.

\footnotetext{
${ }^{14}$ Digital circulation numbers are from Tom Tom's digital edition published on electronic publishing platform issuu.com.
} 
Founding partner of the Hit Like a Girl international drumming contest, which judged more than 1,200 video submissions from 45 countries last year ("This Drummer Takes Pride in Hitting Like a Girl”).

DJ residencies and events at Ace Hotels (the Ace Hotel chain includes up-scale boutique hotels in New York, Palm Springs, L.A., New Orleans, Pittsburgh, Portland, Seattle, London and Panama). Museum takeovers at MoMA ${ }^{15}$, Perez Art Museum Miami, Booklyn Museum, and others.

Tom Tom showcases: informal events hosted in cities worldwide where four bands with female drummers fundraise for the magazine.

\section{Research Sources}

For this case study, information came from emails and in-person interviews with the publisher, as well as back issues of the magazine. The author attended a Tom Tom event, and met the publisher at one of the Ace Hotels where the magazine is distributed. The author also attended the U.S. national music trade show in Anaheim, CA, where the publisher secures the majority of her advertisers. In addition, the author attended the Women's International Music Network's She Rocks awards, where the publisher was an honoree. Although Tom Tom is a private company and full financial statements are not available, the publisher did share percentages of revenue (see more under "Revenue") and how she hopes to expand

15 The Tom Tom MoMA PS1 exhibit was reported on by Smithsonian Magazine for showing "how awesome female drummers actually are," (Eveleth). 
future revenue streams. Citations for data from sources outside of communication with the publisher are provided in the text and bibliography page.

\section{Internal Context (Micro)}

\section{Revenue}

Tom Tom Magazine receives revenue from several sources. Data in the table below are approximates provided by the publisher.

Table 6.0: Tom Tom Magazine Revenue 2015

\begin{tabular}{|l|l|}
\hline Revenue Source & Percentage of Total Revenue \\
\hline Subscriptions & $5 \%$ \\
\hline Advertising & $83 \%$ \\
\hline Single Copy Sales & $2 \%$ \\
\hline Events & $5 \%$ \\
\hline Speaking Engagements & $5 \%$ \\
\hline
\end{tabular}

Advertising includes print and digital, with digital comprising approximately one third and the magazine is "working on growing that more," says Abovitz. 


\section{Brand Extensions}

Although only 10 per cent of Tom Tom Magazine's total revenue comes from events and speaking engagements, Abovitz says these live events create hype, increasing the perceived value of the brand, bringing awareness to its mission, and opening up new partnerships:

"I'm not super focused on subscribers. I think [events have] done an immense amount for our brand. These events have been possibly most impactful in terms of getting the word out about the magazine-subscriber conversions probably to some degree-but mostly hype, which I think is almost more important, the message and the hype."16

Because Tom Tom is guided by a mission, increasing awareness about its goals and disseminating its message is very valuable.

Many of its brand extensions have in fact become revenue streams. For example, promoting female DJ residencies for the Ace Hotel opened the door for Tom Tom to host events at the hotel, and then to stock its rooms with copies of the magazine. Now Ace Hotel is an advertiser in the magazine.

This hotel partnership is not just extending the print magazine, but extending its reach outside of the music industry.

\footnotetext{
16 When reporting as a music correspondent in 2013, the author had a conversation with an all-female band whose new album told tales of strong females. The drummer cited Tom Tom as a positive influence. This drummer also mentioned how much she wished she could get a physical copy of the magazine, which is still not widely distributed in Canada.
} 
Tom Tom also has a presence within the music industry, through distribution in Guitar Centers, through co-founding the Hit Like a Girl Contest with David Levine of TRX Cymbals and Phil Hood and Andy Doerschuk of DRUM! Magazine, by attending trade shows such as the National Association of Music Merchants, and by hosting events at music conferences like SXSW.

However, Abovitz explains the magazine must go outside of the music industry, to reach those who are not yet into music and because sexism still pervades much of the industry, creating a barrier for women and girls:

"[G]irls aren't going to those places (music stores)... so I need to find them where they are, and I need to find allies... and so, I'm working to create more alliances with public libraries, hair salons, nail salons, Urban Outfitters, trying to get to girls and women where they are."

This has led Tom Tom to not only partner with "cool" brands like Ace Hotels, Virgin Airlines ${ }^{17}$, and the Apple Store, but also with respected institutions like museums.

Tom Tom's museum takeovers have occurred at MoMA PS1, Perez Art Museum Miami, and the Brooklyn Museum. The takeovers place female drummers throughout the museum for the day. A beat boxer visits each drummer and learns about their history, and then beat boxes over top of their drumming telling the stories of each drummer to the next.

"Its intention is to show how anyone with an oral history-anyone whose history is not being told in the media or at all—how you find out about it." Abovitz says as a female drummer, she always found out about other female drummers

${ }^{17} \mathrm{~A}$ brand that itself started in the music industry. 
through word of mouth. The museum takeover project is to "physicalize" that

experience. "My goal is to occupy as many museums around the world as I can," says Abovitz.

Abovitz also works with universities and colleges where she coordinates and moderates panel discussions and speaks about feminism and the representation of women in the media. Abovitz conducts approximately 10-12 speaking engagements per year. Discussions have been held in the U.S. and the U.K., and have included topics such as "Women in Music" and "The Power and Persuasion of Music and Media."

\section{Corporate Leadership and Strategies}

From the outset Tom Tom was a social media community as well as an "irl (in-real-life) community." Abovitz credits part of the magazine's success to social media:

"I think that the reason why Tom Tom is what it is right now is in part to do with social media. Without Facebook at that particular time-I remember the business page was brand new when Tom Tom was starting around 20092010 - and feeling like I was incredibly lucky because what social media allowed us to do was sound like an 'us' not just a 'me.' So I was able to create a business page and make Tom Tom seem much bigger than it was. I was able to globally connect with female drummers instantaneously. Without social media I don't know where we would be now....it is the reason why we are as big as we are."

The publisher also views social media as a "two-way road," helping the magazine discover more people around the world who identify as female drummers particularly through Instagram and Facebook.

Abovitz admits much of her brand extension strategy has not been intentional, saying "all of that is an accident. We are supposed to be a magazine. I'm 
just trying to change people's minds... and the way to do that in part is by having a magazine." Abovitz describes her and her team's attitude as "do-or-die." All efforts and alternate revenue streams are to support its mission. Abovitz explains why she chose a print magazine as the flagship product:

"You can't ignore an object. You can ignore a url. I think the assumptions that come with print are: influence, and power, and money, and distribution power. Let's summarize that with power. If you have something in print, or an ad on TV, or you're on the radio, you're powerful. Assumptions that come along with power are knowledge and intellect and truth. All of those things can be very dangerous things, and I ask people... to question their media: just because it's in print does not mean it's more real than something you read in a blog, or on Twitter, but what I think it does say is that somebody worked really, really hard and paid a lot of careful attention, and paid for it. It's perception is that it's better, just automatically, which is why I put Tom Tom in print, because I need people to respect the content we were putting out."

Abovitz is aware that her business approach differs from other niche

independents. When asked by publisher peers how she finds new revenue streams, she answers:

"I throw parties because it's a part of our mission. It's important to me that we bring female drummers together and this is how it's happening. It's not because I was strategizing, I make money because I can't print it if I don't make money and because it's the next secondary political statement...For me it's do or die ... we won't be recognized ever if we don't really put everything into this....When they asked me how I got my advertising, well, I have to. I can't not print, and I can't print it without this, so what are you doing?"

The success of the movement can be seen by others in the music industry.

Kiran Ghandi (previously the drummer for artist M.I.A.) told Mic Magazine that she heard about Tom Tom in 2010, loved what she read and so reached out to Abovitz who invited her to play at a live event. "It was so empowering," Gandhi told Mic. "To go and hang out with people who look like you and who are doing things that are similar - for a woman of color playing the drums: It's a rare thing. You're just used 
to being the only one. It just feels so good to have a community." Ghandi volunteered as Tom Tom's Washington, D.C., correspondent, spreading the "Gospel of Tom Tom," and eventually started Rad Ladies That Drum, an all women's drumming festival that ran for three years in Washington ("Meet the Badass Female Drummers Shaking Up Society's Expectaions").

As previously mentioned, the magazine seeks to increase circulation and awareness for its movement, by placing the magazine in locations outside of the music industry: Ace Hotel rooms, as well as on board Virgin Atlantic flights. However, the latter was not as simple as providing copies to the airline.

Abovitz had to pay for in-flight placement. "It's like baggage," she says. In addition, Virgin required the magazines be picked up in London, U.K., but the cost to ship the magazines from the U.S. to London was prohibitive. Abovitz invested in additional print runs in Bulgaria, where the cost of printing and shipping to London was more affordable ${ }^{18}$. These additional costs and considerations were worth it to Abovitz to further the magazine's mission:

"I really wanted the magazine to be on an airplane. I wanted it to be someplace that other drum magazines are not... It breaks open people's minds that think of us in a certain way, and I hope to do a lot more of those things to challenge people."

The publisher says future revenue streams may include a more robust retail presence than its current online shop, and its creative ad agency consulting on marketing options: “Because Tom Tom is a social change project, ultimately, I'm

\footnotetext{
${ }^{18}$ This international print run spurred by the Virgin deal has led to the magazine being distributed in Berlin, London and Barcelona.
} 
interested in helping larger companies be more ethical and moral about their marketing materials."

Abovitz hopes to build this creative arm of the business in the next three to five years, saying it can point to Tom Tom as an example of its ability to change the media landscape.

Thus, we see mission driving all earnings, including traditional and alternative revenue streams, as well as motivating new and creative partnerships.

\section{Social Identity \& Jobs To Be Done Theory}

Tom Tom's mission is closely linked to social identity. The publication's stated intention is to help women and girls see themselves in the media:

“...because if you can't see yourself in something you can't be it.... and so my primary goal with Tom Tom was to create space for a girl to see herself, or a woman, or an average guy, to see themselves as a drummer, an empowered musician, and I want to keep doing that, I want to keep putting people in the media that otherwise wouldn't be in the media to give them room... One of my goals with the magazine is to create a space to say 'Ah, that's what I look like' or 'That's who I feel like."'19

Thus, the magazine and its extensions do all of the jobs required by social

identity theory. It defines girls and women in music_-specifically in drumming_as

a part of the social reality. It creates a desirable social category for female

percussionists to identity with and once in that group, hosts events for them to re-

${ }^{19}$ Abovitz's passion and thoughts are echoed by comments from U.K. independent magazine expert Steve Watson: "Indie mags are looking for other people in the world who are also passionate about that thing. When you've got that level of passion on the page it really jumps off and grabs you, and that's why people see them as that kind of identifier, that I think is what it's all about...They look a bit like you, their lives are a bit like yours." 
affirm this identity by clustering around people in a physical space who share similar identities.

"I wanted to create a segment of the market that targeted women and girls that was profitable, glossy, sexy, cool. People wanted 'in'," says Abovitz.

Tom Tom thus creates an elite minority "in group" with which readers can self identify. They may not only identify with the magazine, but also with the in group of Tom Tom's larger mission for gender parity. Through its partners, Tom Tom's influence is expanded to include other groups such as travellers, hipsters, first-class flyers, patrons of the arts, and some combination ${ }^{20}$.

\section{Strengths, Weaknesses}

Integral to developing this "profitable, glossy, sexy, cool" in-group was electing to be a for-profit company. Abovitz says "it wasn't like 'we need your hand out because girls and women need you,' I wanted it to be like 'you need girls and women.' Power position. So that's what I'm still pushing for...though I equally wish we could get some kind of break, and I know one kind of break would be becoming a non-profit."

This choice has both positives and negatives. One weakness is this for-profit status stands in the way of accessing non-profit funding. With a mission statement, and a team of volunteers, the magazine is well-positioned to qualify for non-profit support. On the other hand, as mentioned, Abovitz believes its mission requires a

${ }^{20}$ This also includes aspirations to belong to these groups. 
"power position," one that she believes comes from its for-profit corporate structure.

As hype around Tom Tom increases, opportunities continue to arise for brand partnerships (e.g., Ace Hotels in 2009, MoMA in 2010, Virgin Atlantic in 2015). Although the majority of brand partnerships have been sought by Abovitz for strategic alignment, hasty brand partnerships provide a threat. The magazine must be careful to keep events in line with its brand, or risk losing authenticity and compromising the social identity job it does for readers. Abovitz acknowledges this, saying she is still working on how to accept sponsorships and remain genuine.

Despite the strength social media has lent the magazine, Abovitz also acknowledges the threat it poses to its primary revenue source of print advertising. "People are taking their [marketing] budget and splitting it up between everyone...but I think if magazines are patient people will calm down."

She also notes the strain on a small staff when required to manage so many business activities: "What magazines are being asked to do these days...we're being asked to be events companies, to be e-newsletters, to be online platforms, hard copies, to be social media platforms-It's unreal what we're being asked to be and the amount of money we're getting to fund all that stuff... I just started doing whatever I needed to do to survive and that's why I'm positioned where I am."

Despite these weaknesses, Abovitz says she can't afford to ignore social media. For one, she needs to be where her audience is, but also it's now expected to be a part of a magazine's offerings for advertisers. "Plus I love experimenting and 
trying stuff out, and seeing what is social media," says Abovitz. It's clear that the evolution of Tom Tom has been in essence an experiment.

More specifically, Tom Tom has experimented with conversations about gender by asking questions, linking to news pieces to get people talking, asking for feedback about products (e.g., "if our community would be more likely to buy a pink drum set over a black or blue one we ask it there") and testing new topics on social media before including them as regular features in the magazine.

This aspect of social media marries well with the independent magazine's curious and creative ethos, as well as Abovitz's interest in media studies. "What does it mean, what can it do? And it's really cool juxtaposed to a print piece of media or to an event—it's just different, I love it."

Lastly, its mission can also be extended. Currently the magazine has a broader goal of keeping media accountable while trying to change the media landscape in a way that benefits women's involvement in music. The publisher hopes to expand this mission in the next few years by providing consulting advice to other businesses, using Tom Tom as an example of her and her team's success.

\section{Summary}

Tom Tom Magazine shows how an organization's mission can act as a strong business driver. Across a vast array of brand extensions, including events, a social media community, a drumming school, museum installations, and distribution both in and outside of the music industry, the magazine's mission leads its decision making. 
In addition, this case study exemplifies the mission-led business model. We see this model again in Chapter 8, but Tom Tom provides a for-profit example.

As we see, it is not bound by strict non-profit regulations. However, that also means it is unable to take advantage of funding that would otherwise be available to its type of endeavour.

Through a clear mission that intrinsically requires increased reach, the magazine has remained sustainable and found alternative revenue sources, creating a positive feedback loop of hype. This hype results in an increased perceived value of the brand by readers and advertisers, which furthers the job it does for readers looking to identify as female drummers. This feedback also results in greater interest from advertisers.

However, Tom Tom is cognizant of the types of advertising partners it chooses, to preserve the genuine brand readers use to self identify.

Although digital content is a threat to Tom Tom, the magazine came of age at a time when social media was gaining ground. So Tom Tom credits much of its current size to the two-way street that social media offers - finding readers, as well as building hype around its brand creating for itself, and readers, a niche identity, yet one that's loud. It is even loud enough to be carried by (and mentioned in the Wall Street Journal's report on) "elevated" New York newsstands (Kadet).

The majority of this magazine's revenue coming from print does not mean there is a lack of successful business diversification. Instead, success can be seen in the ways these alternative business ventures help achieve the social identity 
objectives orienting this print magazine towards growth, instead of decline, in the face of digital disruptors. 


\section{CASE STUDY 2 (CITY) \\ PALM SPRINGS LIFE MAGAZINE}

\section{Introduction}

"A new category, the city and regional magazine, found a niche as a slick format for local advertisers while providing useful information and occasional solid journalism for a geographically prescribed market."

-Benjamine Compaine, The Business of Consumer Magazines.

Palm Springs Life (PSL) Magazine is a monthly printed lifestyle magazine covering the city of Palm Springs, California, and the extended Coachella Valley region. The magazine is the oldest of those reviewed in these case studies, and is of interest because it exhibits many of the "new" business elements being introduced by magazines in the face of technological disruption.

In particular, PSL is a pioneer in the field of magazines managing events and working in a manner analogous to a creative ad agency. PSL ownership spans two generations, and employs a unique publishing structure of aggregating dedicated topic mini magazines into a larger monthly publication (discussed further under “Corporate Leadership and Strategies"). Before discussing this city publication further, it is important to describe the unique characteristics of Palm Springs itself and the Coachella Valley region.

\section{Background}

"All you need here are swim trunks and dancing shoes... Next to this, L.A. and San Francisco are a pit." -Anthony Sudochi, qtd. in New York Times (no author). 


\section{Palm Springs}

Palm Springs is a municipality located in the Coachella Valley of California, approximately 120 miles east of Los Angeles. The Coachella Valley extends for 45 miles and is composed of nine municipalities. The total population of the valley is 346,000 ("2010 Census Interactive Population Search"). Palm Springs is a popular resort city (as well as a healing destination for people suffering from asthma, arthritis and other diseases) due to its hot and dry climate combined with naturally occurring mineral springs and palm tree oasis. Approximately one million tourists stay in hotels in Palm Springs annually while another 600,000 visitors stay in nonhotel accommodations ("Palm Springs City Profile"). The city has a celebrity status, first well known in the 1930s and 1940s as a winter destination for Hollywood actors and other celebrities (Saeks 11). In the 1970s it was a spring-break destination for youth ("About Palm Springs"). It also has a history of Chicago mobsters investing in the city around the same time. Another name lending it star status is Sonny Bono, who was the mayor from 1988-1992 ("Sonny Bono"). Many of the city thoroughfares are named after resident celebrities, such as Dinah Shore, Frank Sinatra, Gene Autry, Bob Hope, Gerald Ford, Fred Waring, and Bing Crosby.

Today, it is a popular winter destination for all ages, but particularly for "snow-birds" and for youth and celebrities attending the Coachella Valley Music and Arts Festival and the Palm Springs Film Festival (Palm Springs Bureau of Tourism), and it is also known for its mid-century modern architecture, golf courses, tennis tournaments, and LGBT community (Palm Springs Bureau of Tourism). 


\section{Palm Springs Life Magazine}

Palm Springs Life Magazine was founded in March of 1958 by Jerry Brittingham. At the time the magazine was published weekly during the main tourism season (October to May), reporting on golf, tennis, and social events of the desert's early country clubs. In November 1961 the publication became a monthly magazine, published year-round. This expansion created difficulties and in 1962 the magazine was in financial trouble. Sales responsibilities were transferred to the Taylor/Jones advertising agency. Bud Taylor was the magazine's publisher until 1965 when Milton W. Jones bought the company and took over the role of publisher, merging the magazine and the agency into Desert Publications Inc., the overarching corporation that exists today.

Figure 7.0: Palm Spring Life Magazine May 2010

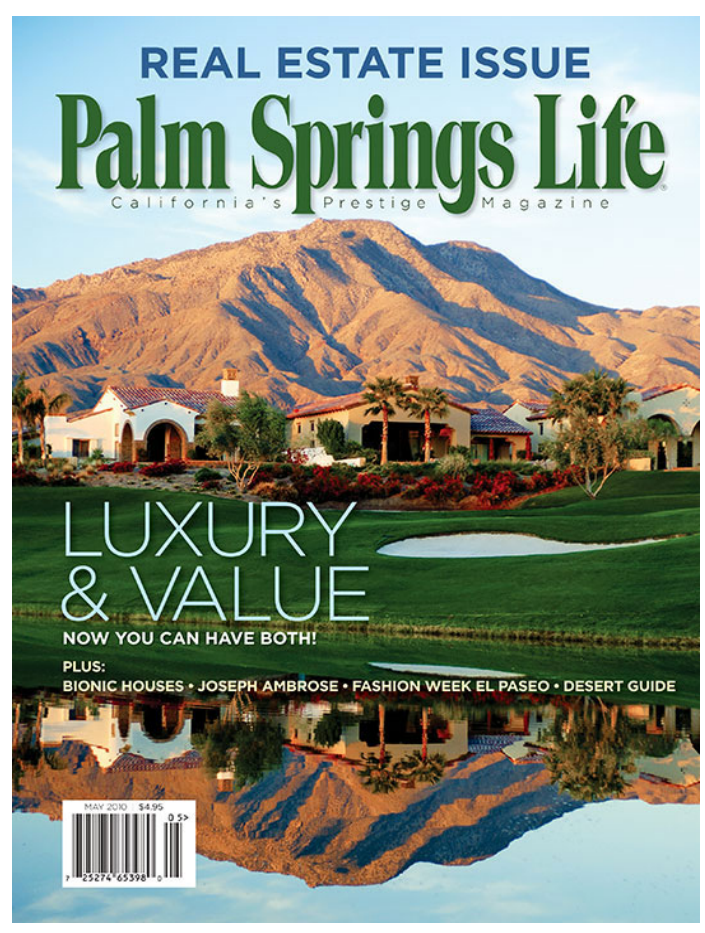


“They were losing about $\$ 100,000$ a year. It took two-and-a-half years for me to put it into the black," says Milton Jones (Biller 102).

Following more than 50 years under the direction of Milton Jones, the publication was then passed down to Milton's son, Frank, who continues as publisher today (from here on referred to as simply "Jones").

PSL is a thick glossy magazine, with each issue generally more than 200 pages, and growing ${ }^{21}$. It was redesigned in 2015 by Canadian magazine designer, Tom Brown, for a more modern look, with a thicker, matte stock used for the cover (Figure 7.1). In 2016 the website was also redesigned to match the print publication's new look.

\section{Figure 7.1: Palm Spring Life Magazine April 2016}

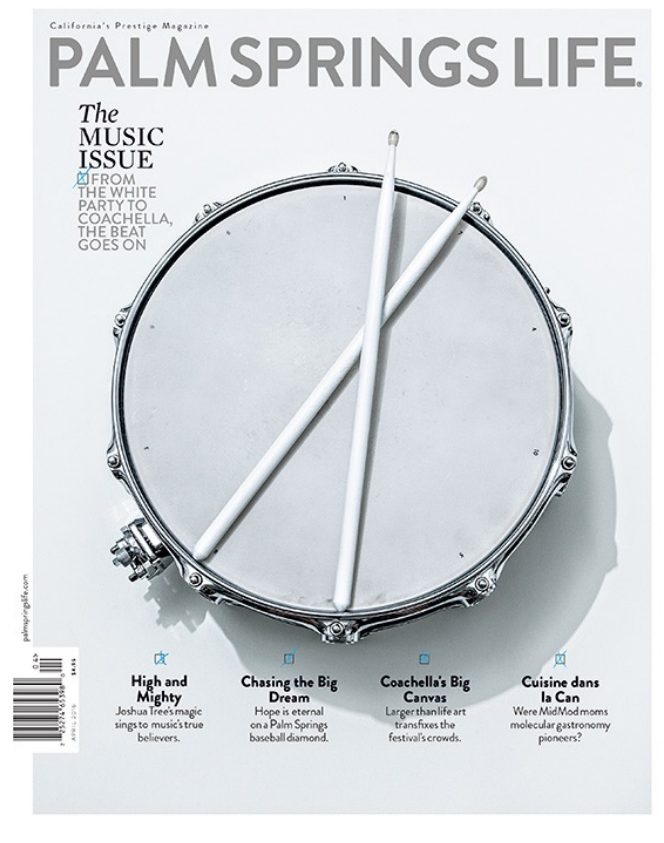

${ }^{21}$ April 2014 "Music Issue" 178 pages; April 2015 "Music Issue” 250 pages; April 2016 "Music Issue” 270 pages. 
Advertisements in the publication often include high-end furniture stores, real estate, jewellers, luxury cars, watches, casinos, galleries, interior designers, restaurants and plastic surgeons.

Monthly editorial content includes fashion, interior design and architecture, the arts, history, upcoming events, major golf and tennis tournaments, horoscopes, fine dining, the social scene, and profiles of celebrity and business leaders.

“Our goal is simple,' says Milton Jones “to give the residents of the Coachella Valley a comprehensive knowledge of desert life in words and pictures," (Biller 103).

Desert Publications Inc. employs a unique "aggregation" publishing strategy, which sees 19 local publications bound into different issues of Palm Springs Life, and then made available two weeks later for free as stand-alone mini magazines around the city.

It has also maintained its ad agency roots, designing and producing publications for various clients, mainly in the travel and tourism industries.

Desert Publications has more than 30 full-time staff, with several freelance editors for its various local insert publications and client projects.

\section{Research Sources}

For this case study, information was gathered through a two-week internship at Desert Publications in Palm Springs, CA, complemented by emails and two inperson interviews, one year apart, with the publisher. Back issues of the magazine were also reviewed. As a private company, Desert Publications Inc. is not required 
to disclose full financial statements. However, the publisher did share approximate percentages of revenue (see more under "Revenue").

\section{Internal Context (Micro)}

\section{Revenue}

Revenue for Palm Springs Life Magazine comes from several sources, led by traditional print advertising. Data in the table below are approximate, provided by the publisher.

Table 7.0: Palm Springs Life Magazine Revenue 2015

\begin{tabular}{|l|l|}
\hline Revenue Source & $\begin{array}{l}\text { Approximate Percentage of Total } \\
\text { Revenue }\end{array}$ \\
\hline Traditional Print Revenue & $75-85 \%$ \\
\hline Digital Revenue & $5-10 \%$ \\
\hline Events & $10-15 \%$ \\
\hline
\end{tabular}

A one-year subscription is US $\$ 42$, and includes digital e-reader access. Single print copies are US $\$ 6.95^{22}$. Digital subscriptions are US $\$ 1.99$ per issue, or US $\$ 19.95$ for a year. Digital subscription revenues are less than one per cent of total revenue. Single copy sales average 20 per cent of paid circulation.

${ }^{22}$ For comparison, a year's subscription in 1958 to the then weekly magazine was US \$6 (two years for US \$10). Single copies were 25 cents. 
The magazine hopes to increase digital revenue as a result of its website redesign in 2016. The website is not behind a pay wall, but not all print articles are uploaded to the website.

\section{Brand Extensions}

"I think you have to be doing other things to drive that commitment to a print subscription,"

-Frank Jones, Publisher Palm Springs Life

PSL's ad agency heritage can be seen in many brand extensions offered by the magazine, most notably, events. Although only 10-15 per cent of PSL's total revenue comes from events, it is one of the first North American city publications to tap into this type of brand extension (more under "Leadership and Strategies").

"We see them as another form of media. It just has physical, time-frame, and interactive qualities to it that are different than other kinds of media. It has the exchange of participants and narrative creators and then the sponsors that participate to be in that mix are just like if you buy an ad in the magazine," says Jones.

According to Jones events also have similar characteristics to magazine subscriptions:

"People subscribe to you through digital experiences in all different ways, paid, free.... People subscribe to you through event platforms. They continue to come back to your events. People subscribe to you in print form .. . I think you have to be doing other things to drive that commitment to a print subscription."

Known for its high-quality printed product, PSL leverages in-house resources to create similar products for others. 
Jones estimates that in the last year it has added a lot more of these "custom publishing titles," with the majority being travel or tourism related. "Because we are in a tourism city, that's what we get hired to do," says Jones.

Currently, PSL creates custom publications for Monterey Bay, Newport Beach, Pebble Beach, El Paso, Vancouver, Greater Ontario California, the Agua Caliente Cahuilla Indians, and the San Gabriel Valley.

In many ways, PSL exemplifies the business structure several other publications have attempted to duplicate by managing events and selling their inhouse skills to outside clients. After being bought by an ad agency in the 1950s, PSL started looking to extend its brand into complementary products. This set the stage for a diversified brand with a print publication flagship that can now grow these related business avenues, instead of having to create them in the midst of disruption.

In addition, it's important to note that the traditional economic model for print magazines doesn't reward increasing subscribers until it reaches a specific threshold at which point advertising rates can be increased due to the larger audience. Therefore, as an established magazine, events and ad agency brand extensions have allowed PSL to increase income without the expense and effort of also trying to increase subscribers above the next advertising threshold.

\section{Corporate Leadership and Strategies}

PSL is a unique example of synergizing the print product with sponsorships, events, and other "agency" work before the most recent technological disruption induced other publications to try the same. This "pioneer in city and regional 
publishing," resulted in Milton Jones being awarded the City and Regional Magazine Association's lifetime achievement award in $2002^{23}$.

The reach of Palm Springs Life goes beyond that of a conventional city magazine, due to the city's "big international name." This extended reach is even reflected in its tagline: “California's Prestige Magazine."

"During golf and tennis tournaments-because of the huge number of hours of national and worldwide television - most of the East and Midwest are up to their cheeks in snow, and people said 'Why aren't I there?' Not very many small town communities get this positive level of attention" (Biller 103).

The magazine even got airtime on The Tonight Show (Johnny Carson owned a vacation property in Palm Springs).

Milton Jones immediately saw an opportunity to extend the influence of the city beyond selling ads in his magazine, by promoting national brands through sponsorships at events. One such sponsorship, for example, was Tanqueray Gin, for which Milton Jones negotiated exclusive pours in several country clubs and restaurants for notable Coachella Valley events in the '60s. For his efforts, Milton Jones received a commendation from Tanqueray Gin, thanking him for his role in helping make their product a national brand (Biller 102).

Today, PSL organizes three large events. The oldest is Fashion Week El Paseo, which takes place in the city of Palm Desert and premiered in 2004. This week-long event showcases the latest collections by top and emerging designers.

${ }^{23}$ Milton Jones' eye for business opportunity can even be seen in his lifetime achievement award. Upon receiving this honour, he thought it was "the ugliest award I've ever seen" and so effected change by having his ad agency take over for the City and Regional Magazine Association, which administers the awards. 
Fashion shows are held in The Gardens on El Paseo (a high-end shopping district) as well as in various stores. Tickets range from US $\$ 35$ (students) - \$75 (general admission) per show. In 2016, the event saw over 12,920 attendees, 200 volunteers, 44 participating stores, and raised more than US $\$ 62,000$ for charity.

PSL next launched the Palm Desert Food \& Wine event in 2010. It runs for three days over one of the weekends of Fashion Week El Paseo. It is also held in the El Paseo shopping district, and invites top chefs, vintners and brewers from across the country to showcase their food and drink. The event begins with a four-course lunch on the Friday, and continues with tastings, celebrity chef demonstrations, and cookbook signings over Saturday and Sunday. In 2016 the event hosted 3,365 attendees, with tickets ranging from US $\$ 100$ - $\$ 225$, and raised an undisclosed amount for the James Beard Foundation.

In 2016, PSL added another event to its roster: The Palm Springs Life Festival. Running for more than a month, this festival extends and encompasses the two others, while adding an arts and music component. It featured performances by opera singer Placido Domingo, the LA Opera Orchestra, violinists Midori and Sarah Chang, cellist Nina Kotova, and pianist Jean Yves Thibaudet at venues such as a casino and various city parks.

"Palm Springs Life Magazine founded the Festival to open up the experience of enjoying the arts to everyone in the Coachella Valley and beyond," Barrett Wissman, the festival's executive director told Forbes magazine ("Birth of a Festival: Palm Springs Life - Forbes"). 
Another revenue stream outside of events and their associated publications, is municipal funding. Although the U.S. government does not offer publishing grants or funding programs, the magazine has been able to access some level of municipal funding.

"Occasionally we call on the city governments to help us fund something that's related to their city, and it's usually involved with creating an event or creating a print product," says Jones. Although Jones explains this is not in the form of a grant, it can cover five to 50 per cent of a project. In addition, events have tapped into the "wealth pocket" of Palm Springs for sponsorships. Aligning with charities, PSL has also been able to secure philanthropic donations to help make large-scale luxury events possible.

Lastly, with only 5 - 10 per cent of revenue coming from digital, there is significant room to grow, especially as only one per cent comes from digital subscriptions.

"I don't feel like I control online," says Jones. "It's very different engagement."

Thus, opportunity exists to expand this revenue source, perhaps by pricing digital subscriptions separately from print to show dual value, as per the Hearst magazine example from Chapter 4.

Although the unique circumstances that make Palm Springs a destination city and a wealth pocket apply only to this city publication, PSL's ability to find revenue sources outside of the region is something any publication can attempt to replicate as strategies for extending a print brand using social identity job theory signposts. 


\section{Social Identity \& Jobs To Be Done Theory}

From its beginning Palm Springs Life demonstrated a good understanding of the social identity role it could play for its readers. "Our goal is simple: give the residents of the Coachella Valley a comprehensive knowledge of desert life in words and pictures" (Kleinschmidt 69).

Today, the publication continues Brittingham's original vision that "celebrates the lifestyle that sets the desert apart," with only a minor change. "These days, however, the celebration extends beyond the country clubs to embrace all the people who call the Coachella Valley home and welcome visitors coming to share the sunshine and relaxing ambiance," (Kleinschmidt 69).

In 2015, the magazine hired a new editor, Kent Black who wrote in his April 2016 editor's letter:

"Before moving here, I was asked by several colleagues how I was going to edit a magazine that would appeal to such a diverse audience. What kind of stories could we devise that would appeal to a straight, retired couple in Indian Wells, a gay couple in Palm Springs, a family in Bermuda Dunes, or a single person in Rancho Mirage? It's taken me a bit, but I'm figuring it out. The thing that unites almost everyone in this valley is that we all love it. Very few people have to be here; we choose to be here," (Black 28)

This geographic "choice" is congruent with researcher Illka Tuomi's notion, discussed in Chapter 2, that people cluster geographically around those who share similar identities. Thus, the editor is already somewhat aware of the role geography plays in how residents define their social identity, and the role the magazine plays in supporting this definition. However, the editor's uncertainty around how to unite 
such a varied population and his focus on content, shows the need for this type of research.

"One of the reasons the city regional category is more successful than other categories, is because, city and regions do need an abstract model to define them," says Jones. “That's what magazines can do ... because they're tangible and encapsulate imagery in a set identity that you can grasp and identify with in a sort of temporary completeness."

This "temporary completeness" refers to the idea that a magazine is temporary in time-a new one will be published in a month-yet, complete in physical existence (as compared to the Internet, where a reader can only have a partial grasp of its contents at any one time). These ideas support the notions described in Chapter 2 under "Why we like printed magazines."

Jones admits the connection offered by the written word is where he specifically enjoys creating a social identity product of high quality:

"The written word ... that's our most imaginative form of modelling. A modelling that can be exchanged, I can exchange it with you, you can exchange it with me, and we can find a sense of belonging and connection there. I think that is the bottom line, and it is that belonging and connection that we're mostly looking for. So that's most satisfying for the magazine... Where I get excited is to strive to continually raise the bar of the quality of that."

\section{Strengths and Weaknesses}

In creating events the magazine has capitalized on opportunities and leveraged its strengths. Milton Jones seized the chance to sell sponsorships due to the city's luxury trend-setting status in the nation, and leveraged its ad agency strength. The magazine has also capitalized on the influx of winter and spring 
tourists by extending its first successful event into two, and now a third overarching festival lasting more than a month. By combining these events, the magazine has expanded the range of events it offers, while ensuring a high level of quality. "We try to control all of the events we're involved with because we have a standard of representation." says Jones.

The magazine also builds on its in-house strengths. For example, the fashion editor co-produces the Fashion Week festival, and the print production team creates custom publications and programs for each event, which are both included in PSL (creating a thicker, more luxurious feeling magazine) and exist outside the magazine as free mini publications in the city (reaching a wider audience).

"Each aggregate has its own life outside of where it comes together with other things," explains Jones. "When you think about those products, they also have aggregate markets."

The success of its events over the last decade has resulted in PSL being approached by other organizations interested in holding events in the Palm Springs area. However, "we kind of keep to our own, because [events] are so demanding, and we want to control them and it's really hard to produce quality events consistently," says Jones.

Although PSL has maintained the level of luxury expected from its brand by combining several festivals, events in general are an avenue for further growth, but one the magazine has not yet been able to scale down market to access. 
Another weakness of hosting multiple events at the same time is that they compete with themselves, which would not be the case if their events were spread out across the long tourism season. We see this in the covers of the magazine at the time of events. To appeal to each market, the magazine runs separate covers (Figures 7.2, 7.3, and 7.4).

Figure 7.2: Palm Springs Life Magazine March 2016 (Fashion)

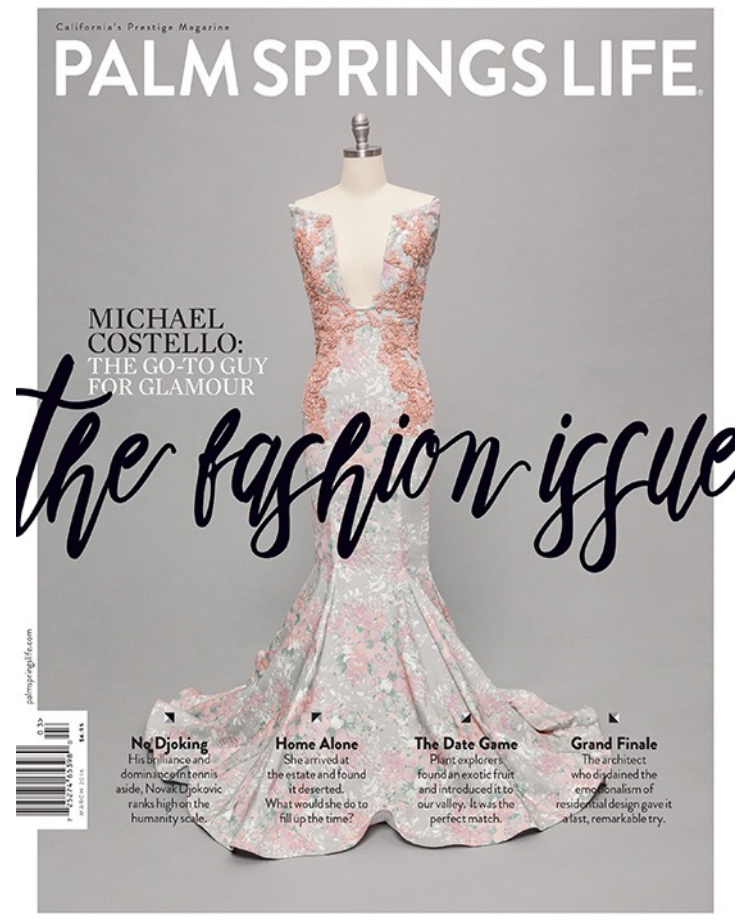


Figure 7.3: Palm Springs Life Magazine March 2016 (Festival)

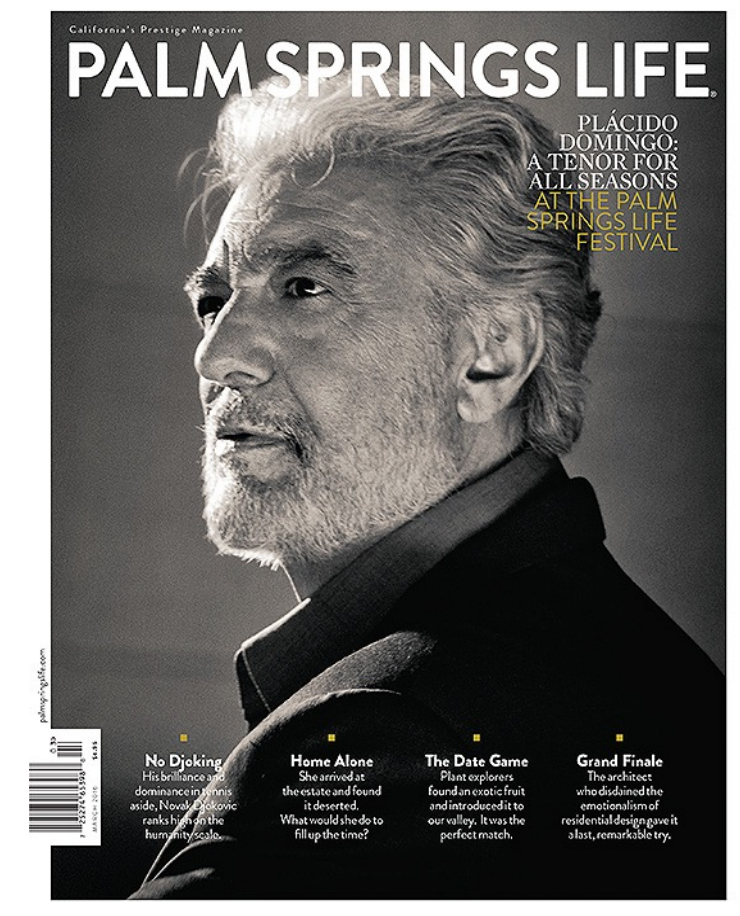

Figure 7.4: Palm Springs Life Magazine March 2016 (Tennis)

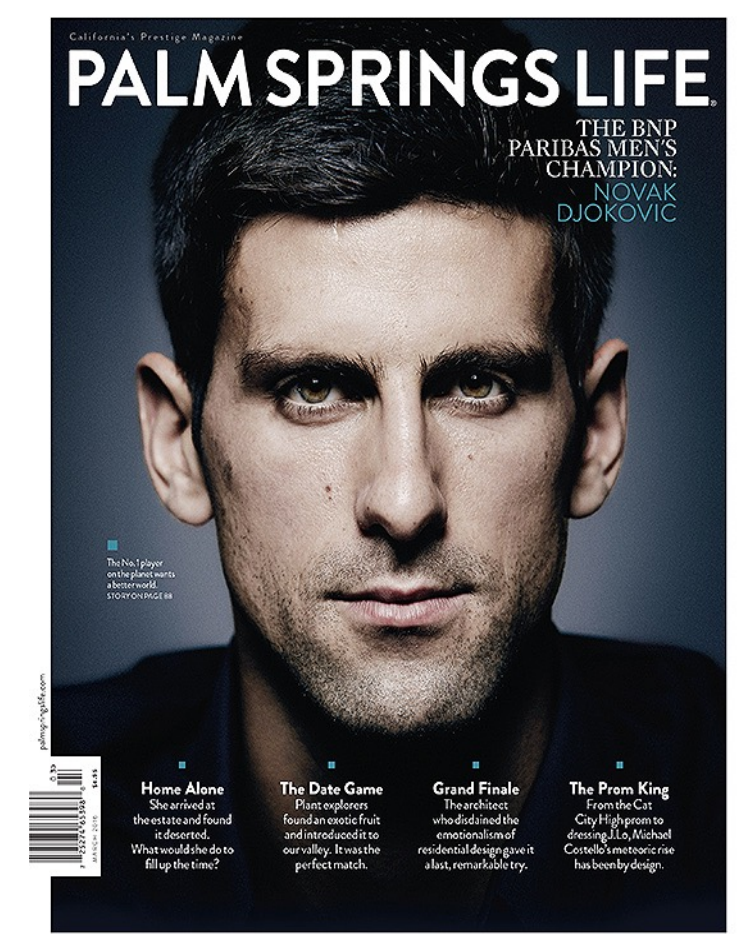




\section{Summary}

Palm Springs Life is a pioneer in city and regional publishing.

For more than half a century, the magazine has succeeded in identifying, cultivating and marketing the lifestyle that "sets the desert apart." Yet, ironically, this social identity exclusivity is also what has made it more attractive and inclusive to advertisers outside the city. From early on, the company understood this "showcase market" identity and took advantage of its posture to broaden the otherwise limited sponsorship and advertising options ${ }^{24}$ that would have existed had it remained solely a print publication.

This was the beginning of PSL as a pioneer in the broader trend of magazines merging print product with ad agency work. The magazine innovated early on with its specialty publications originally conceived as a solution to the off-season summer months. Publisher Milton Jones saw opportunity in the identity Palm Springs created. He realized he could sell the Palm Springs market as a whole, not just as a destination, but as a lifestyle. This brand extension was innovative for supporting a social identity in print and several brand extensions-particularly those with a geographic or physical element-and leveraging the skills of the magazine, which have continued to serve the publication well as alternative revenue streams.

\footnotetext{
${ }^{24}$ Milton Jones said “I copied [Frank Sinatra and Bob Hope's] subscription checks and gave them to our sales staff, took them to New York, and used them to show the quality and value of our readership," (Biller 103).
} 


\section{CHAPTER 8: CASE STUDY 3 (NATIONAL) THE WALRUS}

\section{Introduction}

The Walrus Magazine is the flagship product of The Walrus Foundation, and a unique example of a general interest magazine in Canada coping with technological disruption.

The Walrus is published 10 times a year, and has found new revenue streams from extending its core business (printed magazine) into events, sponsored editorial content and publishing and event services.

These alternative revenue streams are led by events and are a strong point for those looking to self identify with The Walrus' brand.

The Walrus is well-poised to survive technological disruption thanks to high barriers to disruptor entry from its non-profit charity status and its printed legacy product.

In addition, The Walrus is the only general-interest magazine in the country as well as the only national print publication with non-profit charity status in Canada, giving it a considerable advantage. However, its charitable status prevents it from aggressively seeking readership beyond national borders, limiting its market.

Nonetheless, in a competitive industry, The Walrus projects growth on par with global forecasts, and can be considered a success given the difficult market. 


\section{Background}

The Walrus Magazine was founded in 2003, gaining charitable status in 2005.

The Walrus Foundation was established with an educational mandate to create forums for matters vital to Canadians.

Throughout 2006-2008 The Walrus saw revenues decrease, and at that time, in response introduced their first events. By 2012 The Walrus was breaking even, but continues to pay down debts from its first five years of existence. Today, The Walrus generates the majority of its revenue from events, followed by government grants, donations and circulation revenue (adjusted for the Publisher's Grant).

The Walrus employs a staff of 25 , and four paid interns each with 6-month contracts. Its paid circulation is approximately 60,000. The Walrus readership is approximately 300,000.

Figure 8.0 The Walrus April 2015

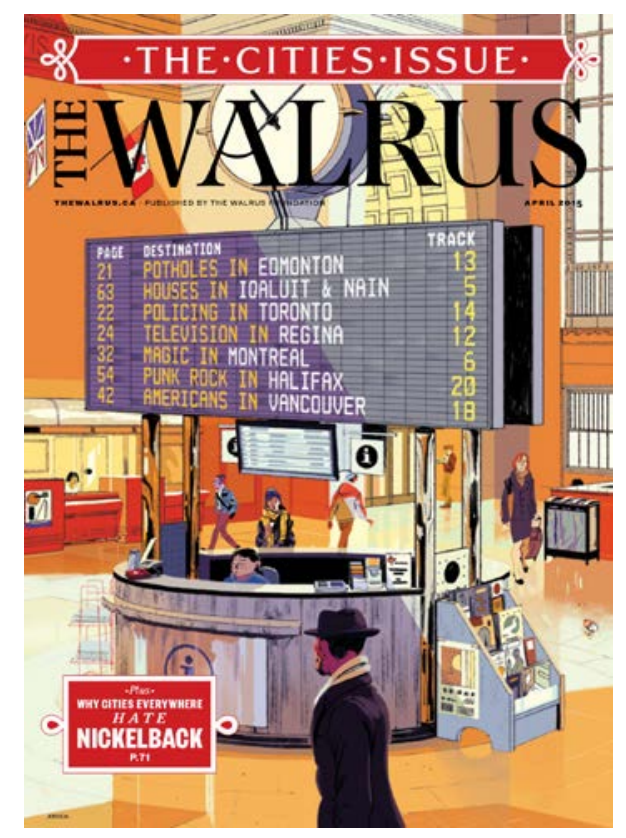




\section{Research Sources}

This case study relies on industry and data reports, government data, and the company's own financial reports. The author conducted a site visit to The Walrus offices in Toronto, and met with the publisher Shelley Ambrose, and several senior staff. The author also attended two The Walrus Talks events in Ottawa, one year apart. Citations for data from sources outside of company financial reports are provided in the text and bibliography page. Company reports follow (Appendix A) ${ }^{25}$.

\section{Internal Context (Micro)}

\section{Revenue}

The Walrus offers print subscriptions for $\$ 29.75$ (10 issues), which includes digital access. Single copies are $\$ 7.95$. Digital subscriptions are $\$ 23.99$ for a year.

The Walrus saw total revenue increase over the last four years (Table 8.0, 8.1, 8.2 and 8.3). It reached a balanced budget in 2012, and a modest surplus was put towards debts incurred prior to 2008 ("The Walrus Donor Report 2014").

${ }^{25}$ The Walrus is the only magazine of the cases studied in this report to offer financial statements. 
Table 8.0: The Walrus Revenue 2012

\section{Revenue (unaudited)}

Fundraising and Development: I,780,073

Donations from Individuals and Foundations: $\quad 988,669$

Event Tickets and Sponsorships: $\quad 740,054$

Charitable Government Grants: $\quad 51,350$

Circulation: I,225,766

Subscriptions: $\quad 673,268$

Industry Government Grant: $\quad 311,274$

Newsstand Sales: $\quad 205,384$

List Rentals: $\quad 35,840$

Sales and Sponsorships: 817,076

Print and Digital Advertising: $\quad \mathbf{5 8 3 , 9 7 0}$

Print and Digital Sponsorship: $\quad 208,850$

Other: $\quad 24,256$

Total Revenue:

$3,822,915$

Table 8.1: The Walrus Revenue 2013

REVENUE (unaudited)

Magazine and Digital Division

Sales: $\quad \$ 1,007,749.31$

Circulation: $\quad \$ 1,288,523.45$

TOTAL \$2,296,272.76

Development and Fundraising Division

Donations: \$881,539.23

Events: $\quad \$ 1,158,895.37$

Charitable Government Grants: $\quad \$ 174,482.38$

TOTAL \$2,214,916.98

TOTAL FOUNDATION REVENUE: $\quad \$ 4,511,189.74$ 
Table 8.2 The Walrus Revenue 2014

\begin{tabular}{ll} 
REVENUE (unaudited) & \\
$\begin{array}{l}\text { Magazine and Digital Division } \\
\text { Sales: } \\
\text { Circulation: }\end{array}$ & $\$ 897,916.80$ \\
TOTAL & $\$ 1,206,109.87$ \\
\hline & $\$ 2,104,026.67$ \\
\hline $\begin{array}{l}\text { Development and Fundraising Division } \\
\text { Donations: }\end{array}$ & \\
Events: & $\$ 1,066,391.70$ \\
Charitable Government Grants: & $\$ 1,209,967.06$ \\
TOTAL & $\$ 50,000.00$ \\
\hline TOTAL FOUNDATION REVENUE: & $\$ 2,326,358.76$ \\
\hline
\end{tabular}

Table 8.3 The Walrus Revenue 2015

\begin{tabular}{|c|c|}
\hline \multicolumn{2}{|c|}{ Magazine and Digital Division } \\
\hline Sales & $\$ 781,666.74$ \\
\hline Circulation & $\$ 1,181,787.24$ \\
\hline Total & $\$ 1,963,453.98$ \\
\hline \multicolumn{2}{|c|}{ Development and Fundraising Division } \\
\hline Donations & $\$ 1,072,995.22$ \\
\hline Events & $\$ 1,468,995.32$ \\
\hline Charitable Gvt Grants & $\$ 62,550.00$ \\
\hline Total & $\$ 2,604,540.54$ \\
\hline
\end{tabular}

\section{Brand Extensions}

The Walrus leverages the perceived brand value of its magazine as an intellectual publication, for new revenue streams. This core business is being extended to bring in revenue through events (dinners, talks, galas), sponsored 
editorial, and one-off activities for clients (books, e-books). Events, are then further extended, and The Walrus is hired to manage aspects of others' events.

\section{Corporate Leadership and Strategies}

The Walrus is led by Shelley Ambrose, publisher and executive director, and Jonathan Kay, editor-in-chief. Jonathan Kay was hired after the previous editor, John Macfarlane, retired at the end of 2014 (after six years at the helm).

John MacFarlane and Shelley Ambrose had shared the publisher role but, following MacFarlane's retirement, Jonathan Kay's position became identified as editor-in-chief, with added emphasis on "Content Platforms." In a news release from The Walrus, Kay said he was looking forward to working with staff to bring the magazine to a wider audience on all content platforms.

Kay's new title illustrates a strategic shift, most apparent with an increased amount of daily content published on thewalrus.ca., The Walrus podcast, and its growing YouTube channel where videos of The Walrus Talks are posted.

\section{Social Identity Jobs-To-Be-Done Theory}

The Walrus' national general interest subject matter, combined with a Canadian educational mandate, creates a broad social identity in-group. In this regard, The Walrus has a challenge in defining and completing the social identity job-to-be-done for its readers. One area where The Walrus succeeds at this challenge is in its events. By creating topic and city-specific events, the magazine has effectively teased out multiple social identities from the magazine's broader in- 
group identity. In addition, by pairing these topics with select cities, The Walrus is able to tap into in groups at the city level.

For example, those who identify as environmentalists live across the country, however, the in-group of environmentalists in Ottawa is different from that in Edmonton, or from that in Montreal. Thus, The Walrus is able to call out this identity in different regions by facilitating The Walrus Talks Energy, for example, in multiple cities, giving attendees the opportunity to affirm and re-affirm their identities in geographically clustered social groups.

Because the discussion can have more than just one identity, a.k.a at least two sides, a The Walrus Talks event can encapsulate two identities, inviting an even larger group to self-identify in a classic us vs. them situation (i.e., you can't be an in group without an out group). In this way though, attendees may be disappointed, and feel like a member of the out group to the organization, if the speakers represent largely one side. In this sense, the organization, facilitation and communication of these events must be in complex balance for the social identity role to be properly marketed so it can, in turn, be delivered in the event. For example, Green party politicians and staff in Ottawa who attend The Walrus Talks Energy may feel like the out group upon realizing it is sponsored by Suncor and the majority of speakers promote tradition energy sources ${ }^{26}$.

26 The author attended The Walrus Talks Energy in Ottawa in 2014, and interviewed a fellow attendee, aid to MP Elizabeth May, Green Party Leader. 
In addition, as touched on previously, being a general interested magazine makes it a challenge to deliver specifically on the social identity job-to-be-done of any Canadian, as this is a broad identity.

\section{Strengths and Weaknesses}

The brand's perceived value is its biggest strength. Ambrose says advertisers want to be in the pages of The Walrus because of this perceived value-the prestige that comes from print inclusion ${ }^{27}$. For The Walrus, its mandate dictates that only 20 per cent of its pages can be ads. These select ads have extended life because, like all print magazines, the product gets passed around, and because generally The Walrus published longer-form pieces, requiring readers to engage with the magazine's content for longer.

Its charity designation allows The Walrus several advantages. It provides another revenue stream. It gives the magazine clear guide-posts to navigate their company and, in this way, it helps define the company and its brand.

Because the charity business model allows it to do anything that fits within its mandate, The Walrus is intrinsically set up with an extendable brand, an advantage that can scale into new markets. There is a boomerang effect here, as new revenue streams (such as events) are further extended (e.g., managing others' events).

At the same time, being a charity has certain limitations. For example, only 20 per cent of its magazine can be ads, and content must be 80 per cent educational

\footnotetext{
27 We see this for Monocle as well.
} 
and 80 per cent Canadian. This makes it particularly difficult to tap into the larger global market other national general interest publications (such as The Atlantic, The New Yorker and Harper's) reach.

Also, sponsors, although carefully vetted to ensure their goals are suitably aligned with those of The Walrus, can have many-possibly alternative-objectives.

Separately, sponsorships from companies with deep pockets are favourable (e.g., oil companies, banks, and beer companies); however, sponsorships can tarnish the brand and the very perceived value advertisers seek in the first place if the products these companies produce are inconsistent with The Walrus identity.

For example, in one post-event survey from The Walrus Talks Energy, in

Edmonton $\mathrm{AB}$ in 2016, one attendee replied:

"Although the topic was alternative energy, in any discussion I would like to hear alternative perspectives. Alternative energy at this event was heavily skewed toward solar power and solar installation. Although the benefits are increasing, all benefits and consequences of a massive shift to solar were not addressed, discussed, or mentioned at all. When we look at issues completely one sided, we miss many lessons, opportunities for progress and discussions," (The Walrus Talks Energy, exit survey, 2016).

Had the respondent looked closer, they may have noticed the event was sponsored by Suncor, which in the same year, announced plans to open its first solar farm, proposed for a city in Alberta.

In another exit survey from The Walrus Talks The Art of Conversation, in Sackville NB in 2014, a respondent did noticed the sponsor, in this case by the Canadian Association of Petroleum Producers, saying:

"Why did you agree to take CAPP money to sponsor this event? I did not realize beforehand that they were your main sponsor. I felt ashamed to be 
there. The petroleum industry contributes mightily to the ravages of climate change..." (The Walrus Talks The Art of Conversation, exit survey, 2014).

\section{Summary}

Despite a competitive external environment, The Walrus sees potential growth that matches the global magazine year-on-year forecast. In such a difficult industry, these gains are big successes. The Walrus may attribute its success to leveraging its extendable core of perceived high value to new revenue streams, namely events, and further leveraging these services by making its resources and expertise available to other event holders.

However, The Walrus should be careful not to jeopardize its brand value by accepting sponsorships from companies whose brands a significant portion of The Walrus readers do not identify with.

As a registered charity, The Walrus is a successful example of a versatile business structure, able to create new revenue streams that remain on-brand as long as they are fulfilling its charitable mandate. At the same time, The Walrus stands to gain from widening its mandate to include global affairs, allowing it to tap international markets as addressed by similar general-interest magazines The Atlantic, Harper's and The New Yorker. 


\section{CASE STUDY 4 (INTERNATIONAL) MONOCLE}

\section{Introduction}

Monocle is published 12 times a year ${ }^{28}$ and distributed globally. Its headquarters are in London, with bureaus in Tokyo, New York, Hong Kong, Toronto, Zurich and Istanbul. The magazine publishes editorial content on international current affairs, business, travel, culture and design. Monocle is an interesting example of a dynamic, growth-oriented independent magazine, one that exemplifies nearly all aspects of brand extensions presented in the case studies reviewed ${ }^{29}$. Similar to Palm Springs Life, it has roots in a creative agency business. It also has many brand extensions including events, retail shops, retail products, travel guides, books, cafés, and an upscale print-retail kiosk franchise. Monocle has a website where all editorial is guarded by a pay wall.

The only brand extension implemented by the other case studies that Monocle does not pursue is social media, although it has successfully found a niche in podcasting digital media via its 24-hour radio app, Monocle 24.

It is evident that part of Monocle's success has been its investment in a highquality print product as well as its role in effectively creating a social identity for readers and advertisers alike.

\footnotetext{
28 Monocle publishes eight monthly issues, and two double issues that span December/January and July/August. However, it also publishes two seasonal newspapers (summer and winter), aimed at reaching readers while on vacation. This equals 12 issues in total per year.

${ }^{29}$ It is also one of the most looked-up to title by the publishers of the other cases studied, as commented on in communications and interviews.
} 


\section{Background}

Monocle was founded by Tyler Brûlé, previously the founding editor of Wallpaper*_a cutting-edge design, style and architecture magazine. In 2007, Brûlé sold Wallpaper* to Time Warner for US \$2.3 million. Following the sale, Brûlé started the creative agency Wink Media (now Winkreative), grown out of a demand from Wallpaper* advertisers for sleek campaigns similar to the Wallpaper* design aesthetic. In 2006, a Winkreative client offered to contribute 10 per cent of the capital Brûlé required to start his next magazine if Brûlé could find four more investors from diversely located family-owned firms. Brûlé did, in total raising 50 per cent of the capital between firms in Catalan, Australia, Sweden, Japan and Switzerland. This was the global start to Monocle, positioned from the outset to report on international business, lifestyle, and travel.

The first issue was published in February 2007. In 2008, it had 7,000 subscribers, and by 2010 that number had increased to 16,000. Today, Monocle has more than 18,000 subscribers worldwide. This growth is particularly impressive considering a subscription to Monocle is priced 30 per cent higher than its newsstand price (more under “Corporate Leadership and Strategies").

Although its tagline describes the magazine as "a briefing on global affairs, business, culture and design", by averaging more than 250 pages per issue, the magazine is much more than a "briefing" 30.

30 The smallest issue to date was 170 pages (issue 50), the largest 308 (issue 69). The inaugural issue (February 2007) was 244 pages thick. 
Sections are divided from A to E, which stand for Affairs, Business, Culture, Design and Edits.

The magazine is printed in colour, on thick stock, with some issues using as many as four different types of paper.

Advertisements are all full pages. They include furniture, airlines, banks, watches, housewares, luggage, and fashion, to name a few.

Monocle does not often conduct reader surveys, and when it does data is not shared publicly. However, we can infer some reader demographics from the most recent reader survey questions posed in the November 2015 issue. These inferred demographics include, world-traveller, interested in global affairs, business, design and culture, holds a C-suite title (COO, CEO, CFO etc...), more than 25 years old, earns more than €120,000 (“Reader Survey—2015” 138).

\section{Research Sources}

For this case study, information was gathered through emails exchanged with the publisher and his staff, through an in-person interview with the publisher at his office in London, U.K., and by reviews of back issues of the magazine. The author also attended a talk by Monocle Editor Andrew Tuck at the 2015 Modern Magazine conference in London, U.K., and visited the Monocle Café in London, and the Monocle Shop in Toronto. Because Monocle is a private company, full financial statements were not disclosed. However, useful financial information came from cross-referencing various media reports. 


\section{Internal Context (Micro)}

\section{Revenue}

The magazine has many potential sources of revenue, and the publisher and editor-in-chief, Tyler Brûlé, is reported as saying that print is its largest revenue source (Mance).

A one-year subscription is $\$ 150$, and includes complete access to all online content. Single print copies are $\$ 12$, however copies in airports are $\$ 16$ and sold as "Express Airfreight Copies, be the first with our news" (Figure 9.0). The single copy price has increased by $\$ 2$ over the last five years. Subscriptions have increased approximately $\$ 25$ since the magazine launched. Digital-only subscriptions are not available. Subscriptions include invitations to Monocle events and a 10 per cent discount on retail items in Monocle Shops.

Figure 9.0: Monocle October 2015 (airport newsstand copy)

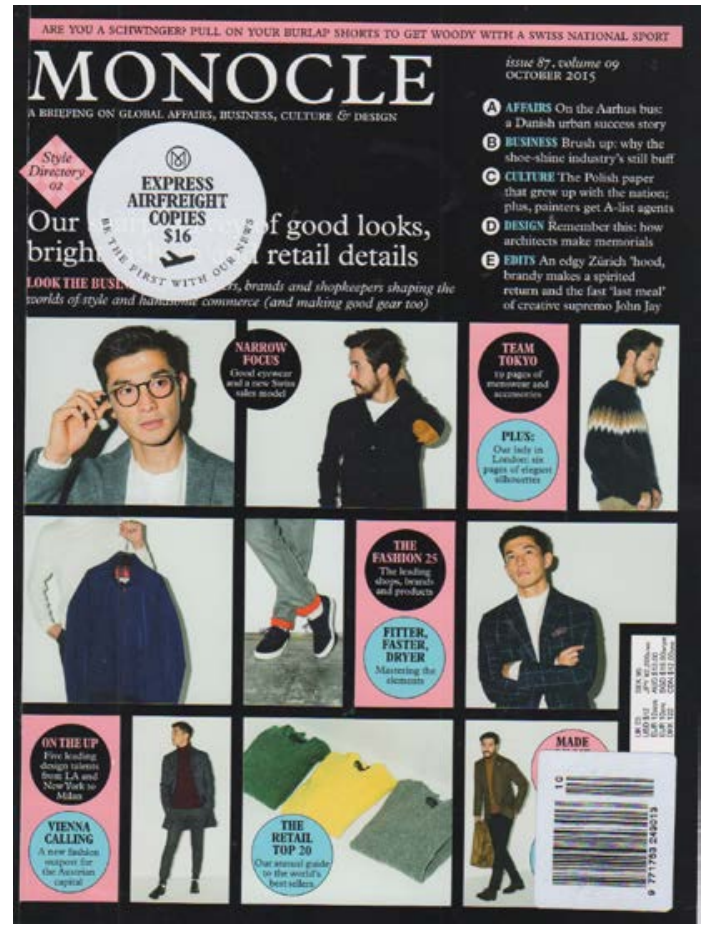


Monocle has grown to approximately 80 full-time staff in 2016 from 19 fulltime staff at the end of 2006.

In 2013, advertising rates were US $\$ 21,500$ for a single page ad and US $\$ 56,000$ for an inside front cover double page. A maximum of 25 per cent of the magazine is advertising.

From the limited revenue reports available, it seems apparent that this magazine is successful. It has been reported that Monocle sold approximately US \$1M in print advertising in its October 2014 issue (Mance). It was also reported that in 2013 the magazine made $£ 600,000$ in profit (Ashton). In 2014, the magazine was valued at approximately $£ 70 \mathrm{M}$, when Japanese media company Nikkei bought a five per cent share-described by Brûlé as "rainy day" money (Ashton).

In addition to print revenue, Monocle also invests in numerous brand extensions. These are discussed in the next section.

\section{Brand Extensions}

In 2010, as Monocle turned just three years old, the publication was already aggressively developing its brand extensions. In his March 2010 editor's note, Brûlé wrote about how Monocle's business had grown beyond a magazine: 
"Upstairs, Pam and Anders on the publishing desk are lining up new extensions to the editorial mix ... a few desks away Kirsty, Sabine and Pauline are negotiating a series of deals that will see new Monocle shops in New York, Toronto, and Tokyo. Around the corner Alex is working on a series of new jingles and special assignments for the Monocle Weekly and there are murmurs that a new audio programme is also in development ${ }^{31}$. On the street below the logistics facility is humming as Gaby and her pixies inspect prototypes for new products and pack orders for shipment near and far. As I survey all of this busy-ness, it's clear that not only has our little editorial venture grown-it's now bursting at the seams."

As Brûlé mentions, these brand extensions include retail stores (the first opened in November 2008); cafés (first in October 2011); a 24-hour Internet radio channel (launched in 2011); editorial products such as travel guides and other books (the first published in September 2013); newsstand café franchises (launched in 2015); and various collaborative products with fashion, fragrance and housewares designers.

Let us explore each extension in brief.

Monocle's international offices are paired with retail outposts in Hong Kong, New York, Tokyo, Singapore and Toronto. Shops sell collaborations between the magazine and designers. For example, the Toronto office is located in the back of the Monocle shop at 776 College Street. This store sells high-end items such as the "Reigning Champ x Monocle Voyage sport shawl" cardigan (\$245), the "Vidoni x Monocle Voyage" neck tie (\$95) and the "ESK x Monocle travel socks" (\$60). In addition to issues of the magazine, the store also sells luggage, fragrances, housewares, stationary, and other Monocle publications (e.g., Monocle's travel guides to cities such as Vienna, Honolulu, London and Paris, and books such as The

31 This would turn out to be the Monocle 24 Internet radio station app. 
Monocle Guide to Good Business, The Monocle Guide to Better Living, The Monocle

Guide to Cosy Homes and How to Make a Nation: A Monocle Guide).

The products sold in Monocle shops were originally conceived as an

advertising option for small manufacturers who could not afford the fees associated with print advertising. These collaborations resulted in the products being sold in Monocle stores, on the website, as well as being included in a print catalogue within the magazine. Today, product collaborations are also available to wholesale clients, as "shop-in-shop" displays (Figure 9.1), and these partnerships are promoted in the magazine.

Figure 9.1: Monocle Shop-in-Shop, from wholesale brochure

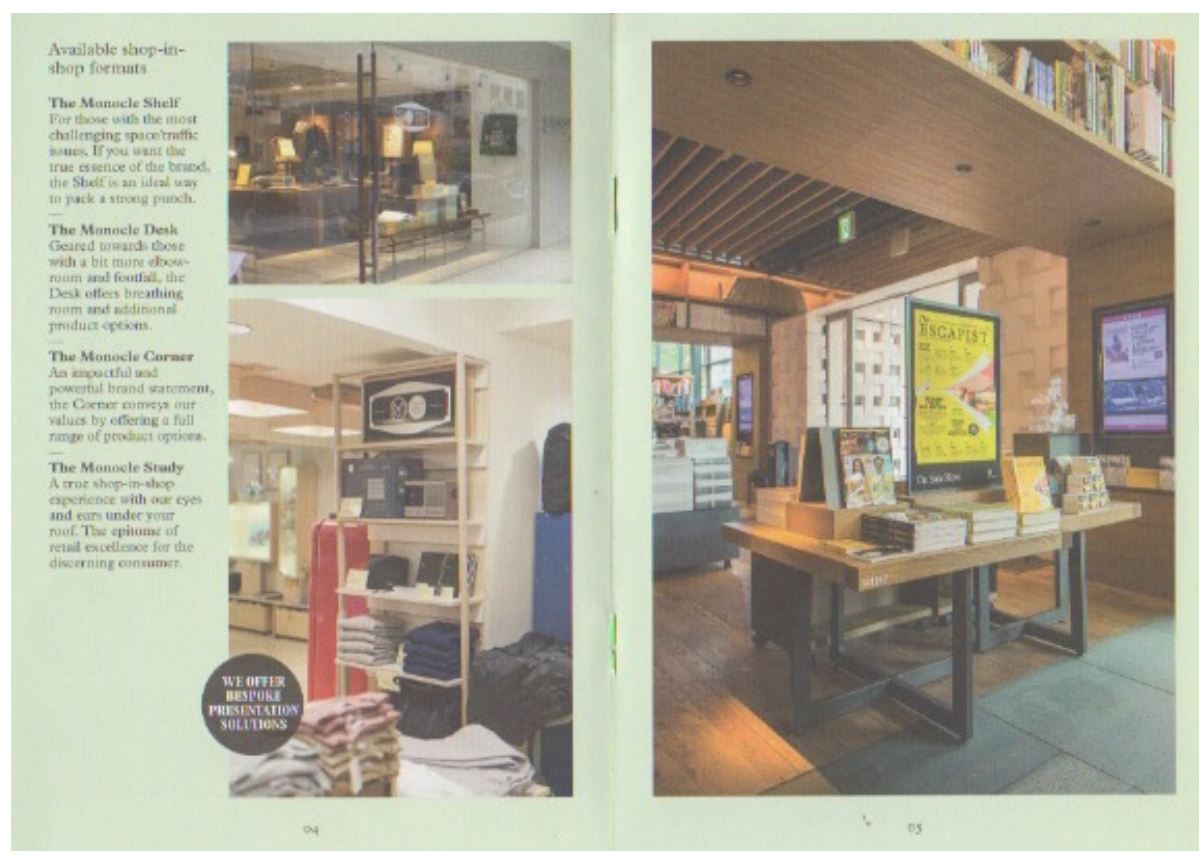

The magazine also owns and operates two cafés (one in London, the other in Tokyo), and recently opened a "Kioskcafé," a combined newsstand/coffee bar in Paddington, a busy London transport neighbourhoods (Figure 9.2). 
"Developed as a sunny, optimistic rebuttal to the rather negative narrative that people aren't buying magazines, that periodicals have had their day and that the future is digital, Kioscafé has a very simple missions: to offer the best selection of magazines and newspapers, backed up by good coffee and an assortment of travel essentials," writes Brûlé in his editor's letter announcing the new venture (290). This outpost offers some 2,500 newspapers via its print-on-demand in-store software, and more than 300 print magazines on its shelves. It also stocks items for travellers such as toothbrushes, shower gels, pens and underwear from luxury brands such as Tehs, Rausch, and Caran D'Ache. The Kioskafé print-retail concept is a franchise and has its own Kioskafé merchandise such as book bags and notebooks ${ }^{32}$.

As Brûlé explains, instead of paying for an expensive billboard, the Monocle store awnings are set up 24 hours a day, every day, advertising the brand. In addition, shops provide revenue for renting the office space in each city, where international correspondents can work.

32 The number of franchises is unknown. 
Figure 9.2: Section from Kioskafé franchise brochure

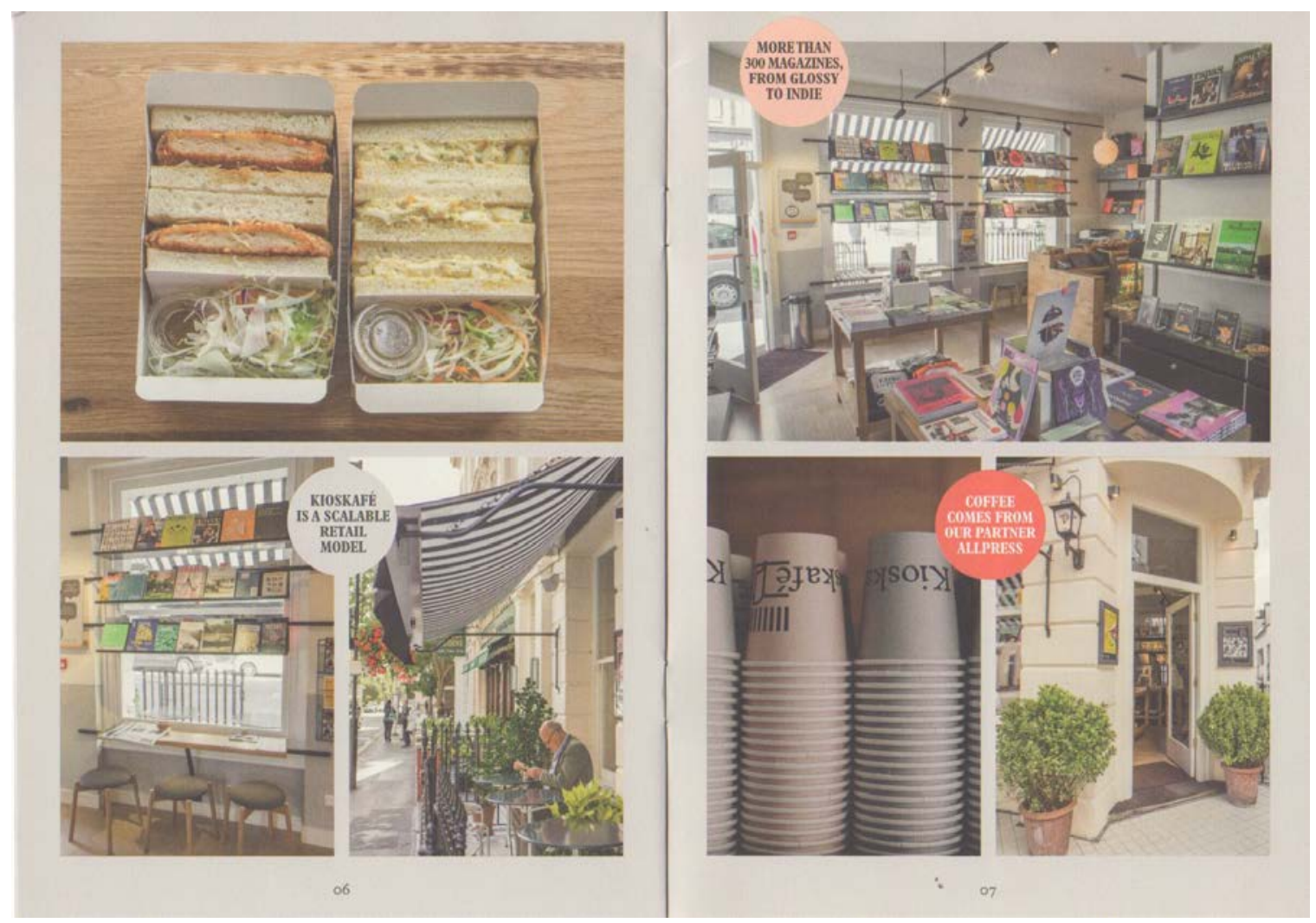

Monocle also organizes several events including pop-up seasonal shops, live podcasts, and an annual Christmas market.

The magazine has seen much success in digital radio. In 2011, Monocle moved its headquarters to a larger office space. The move allowed it to merge offices with its sister company Winkreative, and have enough space to build a series of audio studios. Initially the risk was offset by options to rent out the recording spaces if the expected on-air advertising didn't materialize.

The radio project is Monocle 24, and this digital radio station has over 22 shows and broadcasts 24 hours a day, 7 days a week. Various companies sponsor the shows including Rolex, UBS, Air Canada, Turkish Airlines, and Nike. Monocle 24 
has even been syndicated to CBC Radio Overnight. In a 2015 print insert advertising the app, the magazine answers "Why Radio?" saying:

"Monocle 24 lets us have an intimate conversation with our listeners. In many ways the station has brought the magazine to life... We have also been part of a growing movement that has, in the past three years, seen audio and podcasts come to the fore in the media world. And we see lots of room to grow. So radio feels like a good place for our brand. It fits with our belief in quality, taking time to listen and telling fresh stories in simple ways with no character limit."

The above reference to "character limit" touches on the philosophy of not using any social media, as discussed further in the next section.

\section{Corporate Leadership and Strategies}

Monocle is a success story within the industry by virtue of expanding its print publication into brand extensions with seemingly complementary and lucrative revenue streams.

The decision to go against magazine industry standards, and price single copies below subscriptions was simply a gut feeling. "We just came up with it over a bottle of wine in the kitchen," says Brûlé. "We just felt this is how it should be done," (Bell). Brûlé believes that readers will pay more for quality content and presentation.

In a similar vein, Brûlé had a gut feeling about social media, saying "I firmly believed from the very beginning that these [social media] companies would emerge to be our competitors. And I was proven right." Brûlé cautions that although social media may appear as a free channel to promote your media business' content, it comes with a price: 
"I think that you have to be really honest and say nothing comes for free. You can sort of look at it as this is free advertising, but I would say that you have to then look at what's been eaten into your ad revenue on the other side of it by the fact that your ad budgets might be cut because someone wants to spend more money with a social media company."

In addition to business reasons, he believes Monocle doesn't need another channel since "I have the best outlets in the world to express my opinion" (referring to Monocle, Monocle 24, and his column in the Financial Times). "I think to go beyond what I do now would look a bit sad and desperate."

Brûlé believes social media companies have no substantial content without traditional media companies feeding them. "Twitter doesn't have a story unless CNN feeds it. And the same goes for whatever other outlet." This goes deeper than just advertising dollars. For Brûlé the insatiable hunger of social media for content has resulted in lower quality reporting (in part because media companies are no longer investing in investigative and international reporting). "I think there's a fundamental misunderstanding as what passes for responsible media today ...We think we'll be one of the brands left standing because we are able to go out and report and be out there in the world."

Although his magazine is growing amidst this most recent technological disruption, Brûlé notes many great media brands are not. In this way, Brûlé's decision to keep Monocle out of social media is also a moral one:

"I do not want to be accused of, at some point, as saying 'Yeah, look what happened, social media killed off all of these great brands.' At least I can sort of put my hands up and say 'I'm not guilty,' because I was not facilitating the chatter." 
In some ways, eschewing the ubiquitous platforms of Twitter, Instagram and Facebook makes the Monocle club even more exclusive. It fits with Brûlé's brand beliefs that "people are willing to pay to belong to something that said something about them," ("Tyler Brule Media Maverick").

Interestingly, this type of belonging and identity applies both to readers and advertisers, as discussed next.

\section{Social Identity \& Jobs To Be Done Theory}

"I think this is why we see so many independent self-published magazines than really ever before," says Brûlé when asked about magazines and social identity. "I think it's also why we see magazines that do well, do incredibly well at the moment, because the front cover and everything in between says something about the reader. Yet, I'm quite surprised at how many major corporations have seemed to have missed that memo."

Tyler Brûlé's Monocle is well versed in the role social identity plays in its brand. Like paying for access to an airport lounge, readers pay more ( $\$ 16)$ for a copy of Monocle at the airport; or paying a premium for a subscription vs. a lower cover price for single copies, the subscription is a sign that you are in the club. One of the core areas where Monocle performs best is at establishing and preserving a sense of belonging for its readers.

As Brûlé explains, a tablet only says you are a consumer of one of four options on the market, whereas a print magazine or a newspaper is "a marker of your how you see the world, how you see yourself, and is probably a reflection of 
your economic means." Brûlé goes so far as to suggest, perhaps in jest, that tablets should have an outward facing screen showing everyone what you're reading.

Brûlé's strong sense of identity values percolates through all aspects of Monocle's business-everything from the price of a subscription to the marketing of its products (e.g., Monocle's wholesale brochure says "the products that are available at the Monocle Shop are aimed at satisfying an affluent, opinion-leading, opportunity-driven, design-conscious and truly international audience").

A sense of group belonging, similar to that experienced by readers, is even cultivated by the publication among its advertisers. Advertisers are selected by Monocle for its coveted 25 per cent advertising page limit within the print publication. The process is not as simple as filling out ad specifications and writing a cheque. Instead, a Monocle executive, sometime Brûlé himself, will meet with the brand respresentative to ensure both parties share the same values and convictions. This is further explained by Brûlé in relation to outside creative branding and ad companies interested in learning from the Monocole model:

"They can do TV ads. They can do print ads. They can build websites, but there is something I would say 80 per cent of the people who we meet still want to know: how do you fill the magazine up every month? How do you do five radio shows every single day, write those scripts, find the guests. And you know, there's no magic in it, but it's a craft and it's about a depth of experience and contacts and trust in the brand. None of that happens overnight and yet I'm always amazed that lots of ad agencies just thinks that they can sort of come here and learn it."

\section{Strengths and Weaknesses}

"As an independent media company, we have agility on our side and will continue to embark on new ventures that we feel fit our core mission of keeping an eye (and an ear) on the world," (Monocle 130). As seen from Monocle's rapid growth 
in print and brand expansions, the publication's independence from a large publishing company is a distinct advantage. It can pivot quickly, making decisions that are often based on experience and intuition, rather than industry precedents or focus group research.

The sense of belonging to an elite club-which social identity theory considers a minority group—is deliberately leveraged to secure readers AND advertisers.

In addition, physical brand extensions (such as shops, cafés and events) further reinforce this social identity, and offer Monocle primary data around the social identity jobs-to-be-done objective for their target readership.

As Brûlé comments, “we don’t have to spend money to research who our reader is. We have a very good idea who's buying the magazine, who's buying our products, who is listening to our shows... What's interesting is we haven't done [a reader survey] in five years or something 33 , in part because our advertisers all know that we have stores, and that we do lots of events, and that we're hosting those events ourselves and we're meeting our readers."

However, there is one area where Monocle is not engaging with readers: social media. As Brûlé's previously explained, ad offerings from social media companies entice marketing budgets away from print. However, a noteworthy distinction is that potential advertisers will also spend money on a media brand who itself offers social media advertising. We see this, for example in Tom Tom

33 Monocle published the first reader survey in five years in the issue that was on newsstands the month this interview was conducted. 
Magazine's comments from Chapter 6, where editor-in-chief Mindy Abovitz says she can't afford to ignore social media, as it's now expected to be a part of a magazine's offerings for advertisers.

Nevertheless, the qualities of social media do not marry with Monocle's luxe in-group branding. As Brûlé explains:

"Do you want to be in a gymnasium with a thousand people screaming or do you want to be at a really nice dinner, which is well lit and is in a really intimate environment with a group of people, or one other person, who knows what they're talking about. I prefer to be at a nicely set table with a few other people who are very interesting."

\section{Summary}

Monocle is a successful independent magazine employing brand extensions that include creative agency work, retail, hospitality, books and radio.

Admired by all of the case study publishers included in this thesis, Monocle exemplifies an independent magazine that has kept a print-first strategy, investing in and ensuring its core print product is of high quality.

Monocle management believe its ability to make decisions quicklysometimes even on an intuitive basis—has helped it grow rapidly, diversifying its brand beyond print, but always with a view to building a social identity for its readers.

In addition, Monocle has extended this role to advertisers. This advertising growth and associated identification may be its biggest strength, in the process rejecting the heavy pressure felt by other media companies to have a presence on social media platforms. 


\section{Conclusion}

Print magazines are losing readers and revenue to new digital technologies. The increasing pervasiveness of the Internet, mobile devices, and associated social media have proved disruptive to the print magazine business. This is not the first time innovations in technology have disrupted consumer magazines.

As the introductory step of this research project, a review was conducted of disruption to the legacy business model since its advent in 1850. From this review, it was concluded that publishers who survived past periods of disruption adapted their businesses by focusing on content. However, from a review of this most recent technological disruption, it was shown that recent disruptive innovations have created an avalanche of free content. From this, it was further concluded that innovations in magazine content will no longer be enough by themselves to ensure the survival of individual print publications.

But why should we care about the survival of magazines at all? Why not let them go the way of the pager, or the cassette tape?

Magazines matter in society. Affinity for the printed magazine is sometimes difficult to elucidate, but we know that amongst the other reasons discussed in Chapter 2, they satisfy a human trait for digesting and understanding information about the world around us in a distinctive way. We read more slowly, we comprehend more, and we think more deeply when reading a magazine in printed form. Magazines also matter because they broaden the fourth estate's role in areas where other news outlets fall short. 
In this research, various theories were investigated that might allow the development of a framework that could address the disruption magazine are experiencing today. The objective was to develop a tool that could be used by all magazines to choose beneficial directions in navigating disruptive technology threats. It was determined that a suitable tool could be derived from three established theories: journalism gatekeeper theory, psychology social identity theory, and business disruptive innovation theory. This new multi-disciplinary framework is called the Social Identity Jobs-to-be-done (SIJ) theory.

This study has outlined that in accordance with gatekeeper theory, magazines play an important role in defining our social reality. In accordance with social identity theory, creating this social reality, in turn, plays a role in how readers define their social identity.

Magazines don't just define social reality. They also categorize society into groups, establishing an in group to identify with. Overall, magazines simplify this complex social process by providing a physical basis upon which we can build coherent identities. Through magazine events, stores, cafés, etc... they also can offer a physical nexus where individuals who share similar roles are able to congregate. In an extension to social identity theory as discussed in Chapter 2, this helps with role reaffirmation.

Disruptive innovation theorists argue that advantage matters where it allows people to complete some job that crops up in their lives. This "jobs-to-be-done" philosophy is an approach magazines can use to identify their advantages relative to 
those of a disruptor. This advantage is the role they perform in social identity definition and assertion.

The new framework-Social Identity Jobs-to-be-done (SIJ) theory—offers a wide perspective through which to examine magazine strategies and also suggests guiding principles publishers can apply when selecting business elements to protect, and alternative revenue strategies to pursue.

To explore the appropriateness of this model, case work was conducted on four independent magazines. The independent magazines studied in this research represent a varied cross section of a competitive industry and illustrate the complexities of the magazine business model. Inspecting each case study using SIJ theory, we see where these publications sustain advantages and where they expand their businesses beyond traditional magazine revenue streams.

These case studies were discussed in detail in the preceding chapters and it was concluded that the SIJ framework was applicable.

We can now compare and contrast similarities in their business models. Interestingly, despite broad differences (topic, reach, and geography) between the cases studied, commonalities existed in approaches to new business ventures; specifically, events, agency work, and mission.

\section{Events}

The hosting and organizing of events is a revenue stream employed by all four magazines studied. In the case of The Walrus, the majority of its total revenue comes from this alternate source. Walrus events include both high-end galas, as well 
as the more accessible The Walrus Talks, which are held in cities across the country. These events contribute to The Walrus' social identity job-to-be-done by providing a physical meeting place for those who identify with both The Walrus as a medium for intelligent debate, as well as more specific social identities based on the themes of the events (public policy, environment, business, arts etc...).

Tom Tom also organizes lectures and participates in panels at various international institutions, such as colleges, universities and museums. Its approach for these events is similar to The Walrus', identifying with individuals who are interested in debate and high culture, in Tom Tom's case, on topics of feminism, music and the media. Tom Tom also hosts other events that appeal to a predominantly younger, less affluent market segment. Thus, these publications have succeeded in targeting both high and low-end markets.

In terms of available resources, Palm Springs Life, has found it difficult to produce high-quality events consistently throughout the year, opting instead to host one larger annual festival encompassing multiple events. These events individually feature art, fashion and cuisine.

Frank Jones explains that PSL events offer both curated experiences (similar to editorial) and sell sponsorships (similar to ads). Also, like magazines, Jones says events create "many ways to skin a cat," generating revenue through multiple mechanisms. However, as we see from the example of The Walrus, event sponsorships may risk undermining brand reputation if sponsors do not share the same identity attributes as the attendee group. 
Knowing your readers is something Tyler Brûlé considers an additional benefit events provide to Monocle. Through its own events, Monocle acquires firsthand insight on reader demographics, similar to a reader survey. Monocle events also cater to an affluent community, in this case international travellers, with interests in fashion, housewares, architecture, politics, and bespoke goods.

By extending the print magazine to events, publications are not only broadening their revenue streams, but also, consistent with the SIJ theory, offering a physical symposium within which their members can define and reassert their social identities. As established by researcher Illka Tuomi, material objects (the physical magazine) provide a vehicle to simplify this complex process. Furthermore, Tuomi argues geographic locations provide physical nexus points for individuals to cluster together with people who share similar interests.

Through an individual's association with physical objects and locations, she actively creates this identity not just once, but over and over again, because without constant reinforcement, previously achieved status can be easily lost.

\section{Agency Work}

In addition to events, all four magazines studied engage in some kind of agency work. Creative agency work conducted by PSL, for example, has helped it find clients outside the local region, keeping operations busy designing and producing magazines for others during the slower summer season. These clients select PSL for print work based on the high-end destination identities it has a proven capable to deliver. Similarly, Monocle's sister company, creative agency 
Winkreative, grew from the roots of publisher Tyler Brûlé's first magazine, Wallpaper*, and from advertisers' interests in the luxury creative identity this publication was able to generate for other brands.

Although a separate company, it undoubtedly reflects positively on the magazine since the creative agency designs ads for Monocle advertisers. Looking to the Monocle example, Tom Tom publisher Mindy Seegal Abovitz plans to pursue a similar strategy, using her print publication as proof of the work her team can deliver. In addition, she hopes to work with clients who also want to improve the way women are portrayed in the media.

SIJ theory plays a role in this creative agency activity. Although such work is not directly associated to the social identity job-to-be-done task these publications perform for their readers, the proven ability of these magazines to create a printed product that customers use to define their social identity means clients hire these magazine teams to do the same for their own products. However, brands cannot do it alone. As we learned from Tajfe et al., a key step in the social identity process is defining our social reality-a process done by magazines within the context of gatekeeper theory-not a process brands can perform on their own.

Monocle exemplifies this, collaborating with clients in ways that merge their print product with products of their clients, whether through designing ads, or binding mini product catalogues into the magazine. 


\section{Mission}

Mission communicates an organization's purpose, which may often include public or social good. Although not directly an alternate revenue stream, promoting a mission is a business strategy shared by two of the cases studied in this research: Tom Tom and The Walrus. For Tom Tom choosing a for-profit structure was key to its mission. Meanwhile The Walrus' mission is the result of pursuing a not-for-profit model. Despite their disparate corporate structures, both publications are guided towards alternative revenue streams by mission. Mission-driven decisions have contributed significantly to Tom Tom's growth, leading it to experiment with a wide variety of brand extensions, partnerships, and creative ventures. By comparison, The Walrus has only seen significant growth using one alternate revenue stream: events. The primary difference is that that Tom Tom's mission is satisfying the social identity job-to-be-done for its readers, whereas The Walrus is pursuing its mission devoid of any social identity connection.

From these examples, we see that blending mission with SIJ theory can be powerful-even powerful enough to help at least one niche magazine reach global audiences.

\section{Areas for Further Research}

\section{Subscriptions}

For PSL, part of the impetus for generating revenue through events was that its print edition had reached a comfortable balance between subscriptions and ad revenue relative to publication costs. However, for publications pursuing audience 
growth, subscriptions will need to be priced higher. Even in 1981, author Benjamine Compaine cited observers of the industry who questioned why subscriptions were offered such a "steep discount," considering the convenience of home delivery, as well as the risk posed by the liability of long-term fixed revenue subscriptions amidst "rapidly escalating costs of production." The example of Monocle, whose subscription price is 30 per cent above the single copy newsstand price, demonstrates that subscriptions can be successfully priced at a premium. Related, magazines that offer a digital product, such as PSL, The Walrus, and Tom Tom, should not shy away from pricing bundled print with digital subscriptions in a way that shows dual value, as we see from the Hearst magazine example from Chapter 4 . Subscription pricing policies for both print and digital offerings is one area for further research.

\section{Social Media}

There is a broad spectrum of social media use among cases studied, with Tom Tom at one end (high use) and Monocle at the other. Eschewed by Monocle, social media is viewed by Brûlé as contributing to the demise of print, with advertisers choosing to spend more of their marketing budgets with social media companies. On the other hand, Tom Tom believes offering social media advertising options through the magazine's own channels is expected by its advertisers. Social media is also credited by Abovitz as contributing directly to the magazine's audience growth while helping to fulfill its mission. 
How such magazine expansion into the world of social media fits with the social identity job-to-be-done theory can be considered a subject for further research.

\section{Business Analysis}

Conducting a review of the cases studied using Porter's Five Forces (a business analysis framework) may provide a more in-depth analysis to build upon the SWOT evaluation discussed in this study. Of the cases studied, The Walrus was the only magazine that provided detailed financial information. But even in this case, having more financial information would assist additional business analysis (for example, to see if The Walrus is benefitting from the business innovation component of the periodical fund).

Lastly, further research around industry associations and their marketing initiatives could provide greater insight into how magazines might work collectively to promote the value of print magazines to society.

\section{Not-For-Profit Structures}

Magazines are complex to analyze in regards to their mission. As such, further research on this subject could review why magazines might choose different business structures, whether it be for-profit; for-profit under a non-profit institution; or a charitable non-profit structure. A review of alternate revenue streams that may apply to them under these business structures could also be conducted. Using The Four Lenses Strategic Framework, magazines could be analyzed to determine if they fit the definition of a social enterprise. If they did, 
opportunities for impact investing (where the intention of both investor and institution is to create measurable positive impact beyond financial returns) may be investigated for alternative revenue potential.

This research project concludes that the combined Social Identity Jobs-to-bedone (SIJ) theory can serve as a guide-post for magazines to gauge which advantages to protect and which to extend in a competitive and creative environment that is subject to shifting reader habits, combined with constant technology evolution.

Thus, further research could also be conducted on the application of the SIJ tool developed through this thesis to confirm its applicability to a broader selection of publications that are affected by current or future technological disruption. 


\section{Appendix A}

The Walrus Balance Sheets and Income Statements 2012-2015

2012

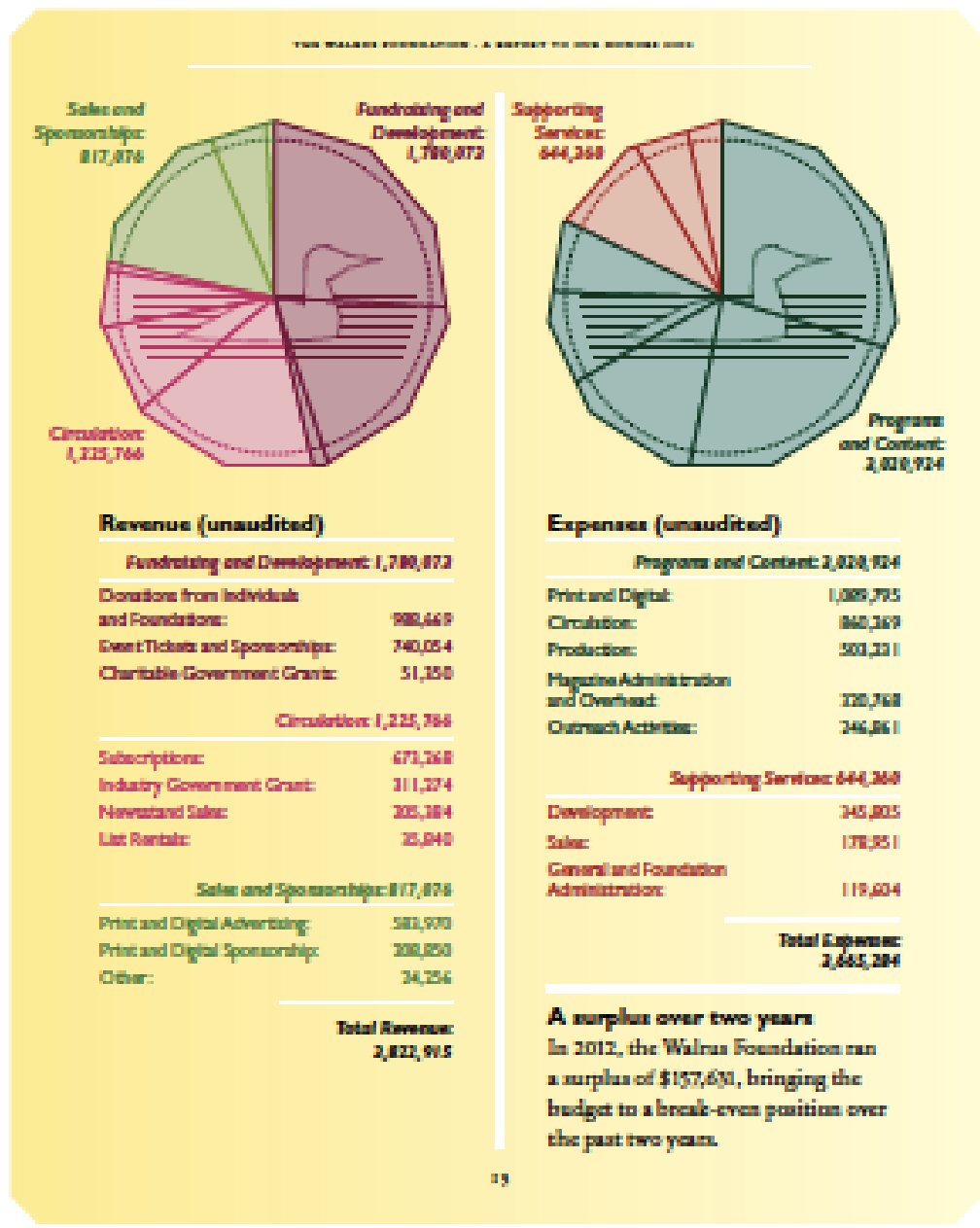

Note: No balance sheet was provided for 2012. 
Financial Snapshot 2013

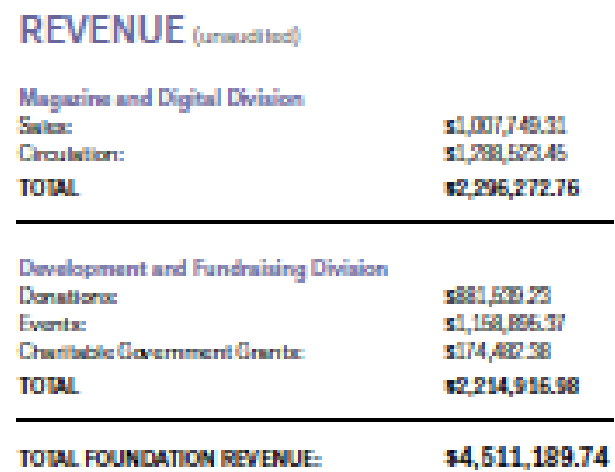

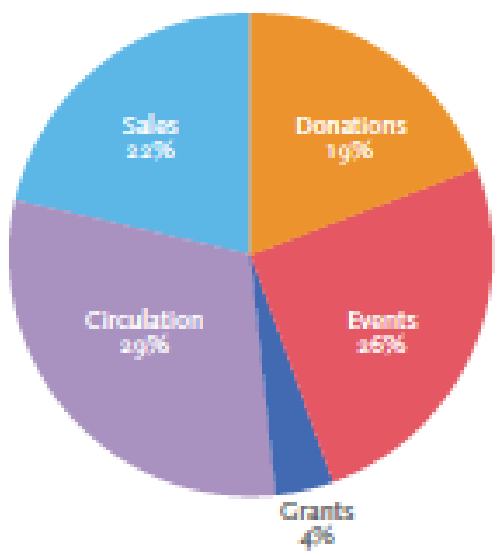

\section{EXPENSES (urausaned)}

\begin{tabular}{|c|c|}
\hline \multicolumn{2}{|l|}{ Magrexirm and Digital Diviaion } \\
\hline Sine: & $3295, \sqrt{10} 15$ \\
\hline Croulation: & sa:a,917 bA \\
\hline Conitent & s],1ति,465? \\
\hline Practuction: & $3529,597 D A$ \\
\hline Asminintration and Derthout: & 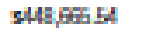 \\
\hline Total & $\mathbf{s}, 153,666.65$ \\
\hline \multicolumn{2}{|c|}{ Development and Fundrwiaing Division } \\
\hline Donationx & $350,3 \% 68$ \\
\hline Eventx: & 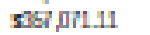 \\
\hline Adrrinintration and Derthout: & $\sin 2 \operatorname{mos} 9$ \\
\hline Total & ต72,543.53 \\
\hline
\end{tabular}

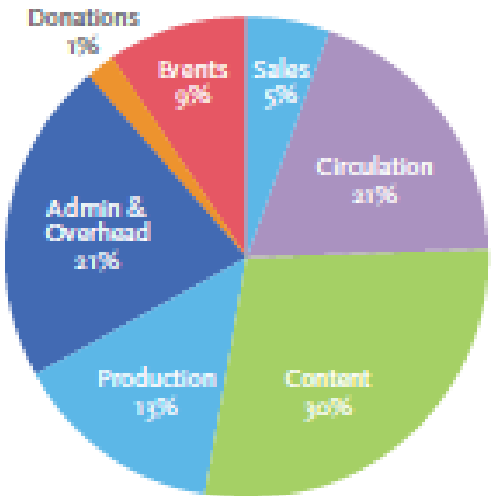

Over the pext thre youn the Welrux Foundation hea scheved

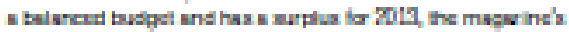
tenth arraverasy your.

Note: No balance sheet was provided for 2013. 
Financial Snapshot 2014

\section{REVENUE (unwalles)}

Maguine and Digital Dwinion

Sine:

Croulation:

seg7,916.80

s1706, 109:A

s2, 104,025.67

Total

Development and Fundraining Divizion

Donations:

Eventx:

Chwrlubie Clavemment Dnante

Total

51.065, 991.N

s.,210,96 .06

s50,0m Do

s2,825,358.76

TOTAL FOUNOATION REVENUE:

$\$ 4,430,385.43$

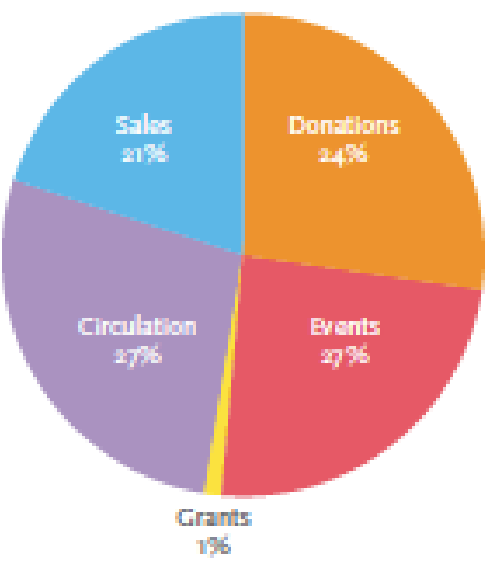

EXPENSES (urnuanes:

\begin{tabular}{|c|c|}
\hline \multicolumn{2}{|l|}{ Maguine and Digital Divinion } \\
\hline Sine: & 241,0932 \\
\hline Croulation: & 5797,06498 \\
\hline Content: & s.720075650 \\
\hline Production: & 3456,10510 \\
\hline Aarninimation and Qverhout: & 3554,97499 \\
\hline TOTaL & s.2.265,495.76 \\
\hline \multicolumn{2}{|c|}{ Development and Fundraining Diviaion } \\
\hline Donationx & $205, \pi 67.4$ \\
\hline Eventx: & 530,38550 \\
\hline Aaminimination and QVertiout: & sta1,9056 \\
\hline Total. & $\mathbf{5 9 4 8 , 0 7 7 . 5 0}$ \\
\hline
\end{tabular}

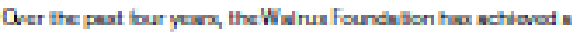

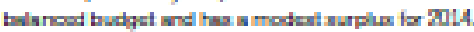

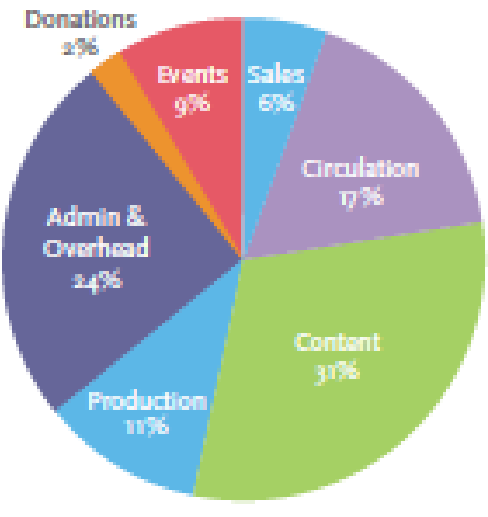




\section{Balance Sheet}

As of Demmber 31, 2014 (unmualled)

ASSETS

Cursent Alaseta

Dhering/ Sewing

Acrounta Poocivatis

$3(72,427$ :02)

375,0256

TORL ASSETS

$51,025,684.01$

LIABILITIES AND EQUITY

Linbiltien

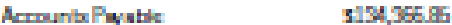

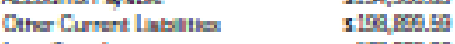

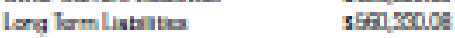

Equity

Retwined Earning $\quad$ 3(79,340,3)

Net Incore $\quad 3211,417$.85

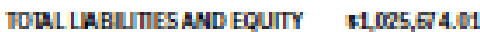




\section{$\underline{2015}$}

The Walrus Foundation

\section{Financial Snapshot}

\begin{tabular}{lr}
\hline REVENUE (unaudited) & \\
\hline $\begin{array}{lr}\text { Magazine and Digital Division } \\
\text { Sales }\end{array}$ & $\$ 781,666.74$ \\
Circulation & $\$ 1,181,787.24$ \\
\hline Total & $\$ 1,963,453.98$ \\
\hline $\begin{array}{lr}\text { Development and Fundraising Division } \\
\text { Donations }\end{array}$ & $\$ 1,072,995.22$ \\
Events & $\$ 1,468,995.32$ \\
Charitable Gvt Grants & $\$ 62,550.00$ \\
\hline Total & $\$ 2,604,540.54$ \\
\hline Total Foundation Revenue & $\$ 4,567,994.52$
\end{tabular}

EXPENSES (unaudited)

Magazine and Digital Division Sales

$\$ 266,508.85$

Circulation

$\$ 789,053.90$

Content

$\$ 1,378,539.67$

Production

$\$ 447,696.17$

Administration \& Overhead

$\$ 461,207.26$

Total

$\$ 3,343,005.85$

Development and Fundraising Division

Donations

$\$ 153,169.01$

Events

$\$ 654,697.30$

Administration \& overhead $\$ 392,880.27$

Total

$\$ 1,200,746.58$

Total Foundation Expenses

$\$ 4,543,752.43$

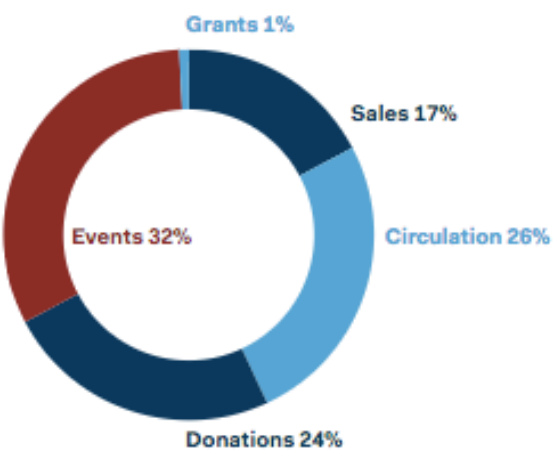

(n)




\section{The Walrus Foundation}

\section{Balance Sheet}

ASSETS (as of December 31, 2015)

Current Assets

Chequing/Savings

$\$ 783,139.80$

Accounts Receivable

$\$ 733,658.67$

Other Current Assets

$\$ 34,576.31$

Other Assets

$\$ 10,402.09$

Fixed Assets

$\$ 73,206.82$

Total Assets

$\$ 1,634,983.69$

LIABILITIES AND EQUITY

(as of December 31, 2015)

Liabilities

Accounts Payable

$\$ 216,825.47$

Other Current Liabilities

$\$ 810,480.50$

Long Term Liabilities

$\$ 540,597.17$

Equity

Retained Earnings

$\$ 22,129.58$

Net Income

$\$ 44,950.97$

Total Liabilities and Equity

$\$ 1,634,983.69$ 


\section{Bibliography}

“About Palm Springs.” visitpalmsprings.com. N.p., n.d. Web. 1 Jan. 2016.

Abovitz, Mindy Seegal. "Letter From the Editor.” Tom Tom Magazine. Summer 2016. Print.

Abovitz, Mindy Seegal. "Interview with Mindy Seegal Abovitz." Personal interview. 25 Jan. 2016.

Abovitz, Mindy Seegal. "Hi Mindy, Outpost Mag and a Few Last Q's." Message to the author. 03 Feb. 2016. E-mail.

Abrahamson, David, Marcia Prior-Miller, and EBSCO Publishing (Firm). The Routledge Handbook of Magazine Research: The Future of the Magazine Form. New York: Routledge, Taylor \& Francis Group, 2015. Web.

Adams, Tim. "Shane Smith: 'I Want to Build the Next CNN with Vice - It'S Within My Grasp." theguardian.com. N.p., 24 Mar. 2013. Web. 1 Dec. 2014.

Alpert, Lukas I. “Comcast’s NBC Universal Agrees to Invest \$200 Million in BuzzFeed." (2015): n. pag. Web.

Allen, Gene. “Old Media, New Media, and Competition: Canadian Press and the Emergence of Radio News" Communicating in Canada's Past: Essays in Media History. Eds: Allen, Gene and Daniel J. Robinson. Toronto: University of Toronto Press, 2009. 47-77. Print.

Alter, Kim. “Social Enterprise Typology.” virtueventures.com. N.p., n.d. Web. 2 Nov. 2015

Alterman, Eric. “Out of Print." The New Yorker, 21 Sept. 2014. Print. Ambrose, Shelley. Personal interview. 20 Feb. 2015. 
American Press Institute. “How Millennials Get News: Inside the Habits of America's First Digital Generation." (2015): 1-40. Print.

Anything Can Happen at a Magazine Stand. Magazines Canada, 2014. Print.

Ashton, James. “Crème Brûlé: how Tyler built Monocle magazine into a $£ 70$ million enterprise." Standard.co.uk. N.p., 5 Sept. 2014. Web. 3 Dec. 2015.

Austin, J E. The Collaboration Challenge: How Nonprofits and Businesses Succeed Through Strategic Alliances. 2010. Print.

Becque, Elien Blue. “The Culture List.” Vanity Fair. N.p., 9 May 2014. Web. 26 June 2016.

Bell, Matthew. "Monocle: It's the Media Project that I've Always Wanted to Do," The Independent, Aug. 1, 2010. Web. Dec. 6, 2015.

Bennett, James. “Introduction.” Media Independence. Ed. James Bennett and Niki Strange. New York: Routledge, 2015. 1-28. Print.

Biller, Steven. "15 Minutes? Try 50 Years!." Ed. Steven Biller. Palm Springs Life Apr. 2008: 100-105. Print.

"Birth of a Festival: Palm Springs Life - Forbes." (2016): n. pag. Web.

Black, Kent. "Editor's Letter." Palm Springs Life Apr. 2016: 28. Print.

Bloomberg West, 20 June 2014. Television.

Boggs, Winthrop S. The Postage Stamps and Postal History of Canada. Lawrence, Mass: Quarterman Publications, 1974. Print.

Bonner, Elizabeth M. Millennials and the future of magazines: How the generation of digital natives will determine whether print magazines survive, ProQuest Dissertations Publishing, 2015. 
Bosman, Julie. “Literary City, Bookstore Desert.” The New York Times 25 Mar. 2014:

n. pag. Print.

Brûlé, Tyler. "Interview with Tyler Brûlé." Personal interview. 28 Oct. 2016.

Brûlé, Tyler. “Observations Issue 87." Monocle Oct. 2015: 290. Print.

“Canada Periodical Fund (CPF) - Business Innovation Applicant's Guide, 2014-

2015." (2014): n. pag. Web.

Canada Post Corporation 2014 Annual Report. Canada Post Corporation 2014 Annual

Report. Canada Post, 2014. Print.

Carr, David. "Covering the World of Business, Digital Only." NYTimes.com. N.p., 23

Sept. 2012. Web. 18 Mar. 2015.

Christensen, Clayton M, and David Skok. Be the Disruptor. Vol. 66. 2012. Print.

Christensen, Clayton M, Michael E Raynor, and Rory McDonald. “What Is Disruptive Innovation?" (2015): n. pag. Web.

Cocaine Cowboys. Dir. Billy Corben. Rakontur, 2006. Film.

Compaine, Benjamin M. The Business of Consumer Magazines. White Plains:

Knowledge Industry Publications, 1982. Print.

de Botton, Alain. The News. London: Signal, 2014. Print.

Doctor, Ken. "The newsonomics of Hearst Magazines' one million new customers."

Nieman Lab. 13 June 2013. Web. 8 Dec. 2014. newsonomics.com

Donsbach, Wolfgang. "Journalism as the New Knowledge Profession and

Consequences for Journalism Education." Journalism. 15.6 (2014) 661-677. Sage. Web.

Duke, Lisa. "Black in a blonde world: Race and girls' interpretations of the feminine 
ideal in teen magazines." Journalism and Mass Communication Quarterly, vol. 77, no. 2, 2000., pp. 367.Emerson, J. The Nature of Returns: a Social Capital Markets Inquiry Into Elements of Investment and the Blended Value Proposition. 2000.

Print.

Electrical Engineer. 4 September 1895: 233. Print.

Emerson, J, S Bonini, and K Brehm. The Blended Value Map: Tracking the Intersects and Opportunities of Economic. Social and Environmental Value Creation, 2003. Print.

Eveleth, Rose. "This Museum Exhibit Shows How Awesome Overlooked Female Drummers Actually Are." smithsonianmag.com. N.p., 21 Nov. 2013. Web. 26 June 2016.

Fact Book 2015. Magazines Canada, 2015. Print.

Fagan, Brian M., and Charlotte Beck. The Oxford Companion to Archaeology. New York: Oxford University Press, 1996. Web.

Forsythe, A, M Nadal, and N Sheehy. "Predicting Beauty: Fractal Dimension and Visual Complexity in Art." British journal of ... 102.1 (2011): 49-70. Web.

Fox, Justin. “A New Golden Age for Media?” The Atlantic, 16 April. 2014. Web. 2 Nov. 2014. theatlantic.com

Garlock, David, ed. Pulitzer Prize Feature Stories. Second Edition. Ames: Blackwell Publishing, 2003. Print.

Glapka, Ewa. Reading bridal magazines from a critical discursive perspective, Palgrave Macmillan, New York, NY; Houndmills, Basingstoke, Hampshire;, 2014. Print. 
Global Entertainment and Media Outlook 2009-2018. 2014. Print.

Godeke, Steven, and Doug Bauer. Philanthropy's New Passing Gear: Mission-Related Investing. New York: Rockeleffer Philanthropy Advisors, 2008. Print.

Gergor, Steven. "Publishing Goes Darwinian." Gym Class Magazine. Autumn 2014. Gunelius, Susan. “When Will Newspapers Become Extinct?.” aci.info. N.p., 29 Aug. 2014. Web. 1 May 2015.

Harcup, Tony, and Deirdre O'Neill. "What Is News? Galtung and Ruge revisited." Journalism Studies, vol. 2, no. 2, 2001., pp. 261279.doi:10.1080/14616700118449.

Harji, Karim, and Joanna Reynolds. State of the Nation Impact Investing in Canada. Print.

Haughney, Christine. “Newsweek Plans Return to Print.” NYTimes.com. N.p., 3 Dec. 2013. Print.

Heyman, Stephen. "Assessing the Health of Independent Bookshops." The New York Times. The New York Times, 26 Feb. 2015. Web. 02 Jan. 2016.

Husni, Samir. "Mr. Magazine ${ }^{\mathrm{TM}}$ Press." Mr Magazine Press. N.p., n.d. Web. 1 Aug. 2015. IKEA Singapore. "Experience the power of a book book ${ }^{\mathrm{T}}$." Online video clip. YouTube. 3 Sept. 2014. Web. 5 Jan 2016.

"Implications of Digital Device Fragmentation." Alliance for Audited Media. N.p., n.d. Web. 7 Mar. 2015.

“Indie Bookstores Fill Void Left by Borders." (2015): n. pag. Web. Investing for Social and Environmental Impact. Investing for Social and Environmental Impact. 2009. Print. 
Iyer, Pico. The Art of Stillness. New York, NY; Simon \& Shuster, 2014. Print.

Jere, M., \& Davis, S. (2011). An application of uses and gratifications theory to compare consumer motivations for magazine and Internet usage among South African women's magazine readers.Southern African Business Review,15(1),127.

Jones, Frank. "Interview with Frank Jones." Personal interview. 25 Jan. 2016.

Jurkowitz, Mark, and Tom Rosenstiel. The Search for a New Business Model. 2012. Print.

Kadet, Anne. "A New Take on the New York City Newsstand." wsj.com. N.p., 11 Dec. 2015. Web. 26 June 2016.

Blumler \& E. Katz (Eds.), The uses of mass communication: Current perspectives on gratifications research (pp. 19-34). Beverly Hills, CA: Sag

Kennedy, Dan. Wired City. Amherst: University of Massachusetts Press, 2013. Print. Kirkland, Sam. "Why The Seattle Times lowered its paywall during the mudslide — but not completely." Poynter Institute. 11 April 2014. Web. Dec. 8, 2014. www.poynter.org

Kleinschmidt, Janice. “Psst!.” Ed. Steven Biller. Palm Springs Life Apr. 2008: n. pag. Print.

Knight Foundation. Finding a Foothold. 2013. Print.

Kollock, Peter, Marc A. Smith, and MyiLibrary. Communities in cyberspace, Routledge, New York;London;, 1999;2002;1998;..doi:10.4324/9780203194959.

Krashinsky, Susan. “Huffington Post Sets Up Shop in Canada.” N.p., 26 May 2011. Web. 1 Dec. 2014. 
Lavenda, Robert H., and Emily A. Schultz. Anthropology: What does it Mean to be Human?. New York: Oxford University Press, 2008. Web.

Leslie, Jeremy. The Modern Magazine. London: Laurence King Publishing, 2013. Print.

Lichterman, Joseph. "If the Philadelphia Newspapers Wanted to Convert to Nonprofits, What Would Stand in Their Way?." Nieman Journalism Lab (2015): n. pag. Web.

Linton, Ralph. The Study of Man. Appleton Century Crofts, Inc., 1936. Print. Love, Robert. The Best of Rolling Stone. Bantam Dell Pub Group, 1993. Print. “Magazines Boomed During 2014." “Magazines Boomed During 2014.” (2014): n. pag. Web.

“Magazine Market Data.” “Magazine Market Data.” ppa.co.uk. N.p., 2015. Web. 29 Mar. 2016.

Mail Classification Schedule 2015. Postal Regulatory Commission, 2015. Print. Maley, David. "Mother Jones Wins Izzy Award for Independent Media." ithaca.edu. N.p., 3 July 2013. Web. 1 Mar. 2016.

Mance, Henry. "Tyler Brûlé’s Monocle Magazine Valued at \$115m." FT.com. N.p., 1 Sept. 2014. Web. 3 Dec. 2015.

Marshall, Joseph Bisat. “Indie Mag Renaissance.” eyemagazine.com. N.p., 3 Oct. 2014. Web. 8 Mar. 2015.

Marvin, Carolyn. When Old Technologies were New: Thinking about Electric Communication in the Late Nineteenth Century. New York: Oxford University Press, 1988. Print. 
Mcllroy, Thad. "Future of Publishing: the Future of Magazines." N. p., 1 Dec. 2014. Print.

McQuail, Denis. Media Accountability and Freedom of Publication. Oxford: Oxford University Press, 2003. Print.

"Meet the Badass Female Drummers Shaking Up Society's Expectaions ." (2015): n. pag. Web.

Mersey, Rachel Davis. Can Journalism Be Saved?: Rediscovering America's Appetite for News. Santa Barbara: Praeger, 2010. Print.

Mettler, Lizzie Garrett. “The Great Indie Magazine Explosion: a Survey.” N.p., 26 Sept. 2014. Print.

Meyer, Philip. The Vanishing Newspaper. 2nd ed. University of Missouri Press, 2009. Print.

"Mission." Tom Tom Magazine Jan.-Feb. 2016: 0-1. Print.

Mitchell, Amy et al. The State of the News Media 2014. Pew Research Center, 2014. Print.

Molotch, Harvey, and Marilyn Lester. "News as Purposive Behavior: on the Strategic Use of Routine Events, Accidents, and Scandals." American Sociological Review 39.1 (1974): 101-112. Web.

“Monocle's Tyler Brûlé: “I Don”t Care About Social Media and iPads'.” “Monocle's Tyler Brûlé: “I Don”t Care About Social Media and iPads'.” Web.

Monroe, Maria R. The Future of the Women's Magazines: Women's Use of Print and Online Women's Magazines in the Digital Age, ProQuest Dissertations Publishing, 2014. 
Moos, Julie. "The Atlantic Publishes Then Pulls Sponsored Content From Church of Scientology." poynter.org. N.p., 15 Jan. 2013. Web. 1 Dec. 2014.

Mott, Frank Luther, 1886. A History of American Magazines 1850-1865. Cambridge, Mass: Harvard U. Press, 1930. Print

O'Donohue, N, C Leijonhufvud, and Y Saltuk. Impact Investments: an Emerging Asset Class. J.P. Morgan, 2010. Print.

Orlean, Susan. "The American Man at Age Ten." Esquire Dec. 1992. Web.

“Palm Springs City Profile." ci.palm-springs.ca.us. N.p., n.d. Web. 3 Apr. 2016.

Palmgreen, P. (1984). Uses and gratifications: A theoretical perspective. In R. Bostrom (Ed.), Communication Yearbook 8 (pp. 20-55). Beverly Hills, CA: Sage

Payne, G. A., et al. "Newspapers and the Internet: A uses and gratifications perspective." Ecquid Novi: African Journalism Studies, vol. 24, no. 1, 2003., pp. 115-126.doi:10.3368/ajs.24.1.115.

"Penthouse to Shutter Print Magazine, Go Digital." "Penthouse to Shutter Print Magazine, Go Digital." (2016): n. pag. Web.

"Pitchfork Weekly - a Digital Magazine Paying Homage to the Past | Ben Cardew." (2013): n. pag. Web

Poell, Thomas, and Jose van Dijck. "Social Media and Journalistic Independence." Media Independence. Ed. James Bennett and Niki Strange. New York: Routledge, 2015. 182-201. Print.

Porter, M E, and M R Kramer. "Creating Shared Value." Harvard business review (2011): n. pag. Print. 
Postman, Neil. "Now...This." Amusing Ourselves to Death: Public Discourse in the Age of Show Business. Toronto: Penguin. 1986. 99-113. Print.

“Publishing Mail Rate Card.” Jan. 2016. Web.

Raabe, Natalie. "Statement From the Atlantic." N.p., 15 Jan. 2013. Web. 1 Dec. 2014.

Raynor, Michael E. The Innovator's Manifesto. Crown Business, 2011. Print.

"Reader Suvery--2015." Monocle. N.p., Nov. 2015. Print.

Riley, Sam G. Consumer Magazines of the British Isles. Westport, Conn: Greenwood Press, 1993. Print.

Robb, Alice. "92 Percent of College Students Prefer Reading Print Books to EReaders." newrepublic.com. N.p., 14 Jan. 2015. Web. 1 Mar. 2015.

Rowlands, Barbara. "Interview with Barbara Rowlands." Personal interview. 29 Oct. 2016.

Ruggiero, Thomas E. "Uses and Gratifications Theory in the 21st Century." Mass Communication and Society, vol. 3, no. 1, 2000., pp. 3-

38.doi:10.1207/S15327825MCS0301_02.

Rutherford, Paul. "The People's Press: The Emergence of the New Journalism in Canada, 1869-99 " Canadian Historical Review. 2.56 (1975) 170-91. University of Toronto Press Journals. Web. September 28, 2014.

Sanz, Esteve, Jean Paul (Senior researcher) Simon, Giuditta De Prato. Digital Media Worlds: The New Economy of Media. New York; Houndmills, Basingstoke: Palgrave Macmillan, 2014.

Sasseen, Jane, Katerina-Eva Matsa, and Amy Mitchell. The State of the News Media 
2013. Pew Research Centre's Project for Excellence in Journalism, 2013.

Print.

Sebastian, Michael. "Hearst Plans New Print Magazine for Early 2016." adage.com.

N.p., 31 Dec. 2014. Web. 31 Dec. 2014.

Seits, Theresa Schaffer. Elementary School Student Reading Fluency: Evaluating the Differences Between the Application of Computer and Print Text Presentations. Diss. Nova Southeastern University, 2013.

Shecter, Barbara. "Eight Media Barons Staking a Claim in the Future of the News Business." National Post. 10 Oct, 2014. Web. Dec. 8, 2014.

www.business.financialpost.com

Shoemaker, Pamela J, Tim P Vos, and Stephen D Reese. "Journalists as Gatekeepers." Handbook of Journalism Studies. Ed. Karin Wahl-Jorgensen and Thomas Hanitzsch. New York: Routledge, 2009. Print.

Siddall, Liv. "An Interview with the Editor of Pitchfork, Brandon Stosuy." N.p., 24 Nov. 2014. Web. 1 Dec. 2014.

Smith, William. The History of the Post Office in British North America. Cambridge [Eng.]: The University press, 1920. Print.

“Sonny Bono.” wikipedia.org. N.p., n.d. Web. 3 Mar. 2016.

Steckel, R H, J Simon, and N Tanen. Making Money While Making a Difference: How to Make a Profit with a Nonprofit Partner. High Tide Press, 1999. Print.

Sumner, David E. The Magazine Century: American Magazines since 1900. 9.; 9 Vol. New York: Peter Lang, 2010. Print.

Sweney, Mark. "BuzzFeed Hires Heidi Blake to Head UK Investigative Journalism 
Team." (2015): n. pag. Web.

Tajfel, Henri. Differentiation Bewteen Social Groups. London: Academic Press, 1978. Print.

Tattersall, I. 2008. An evolutionary framework for the acquisition of symbolic cognition by Homo sapiens. Comp. Cogn. Behav. Revs 3: 99-114.

"The Publishing Playbook by Human After All." The Publishing Playbook by Human After All. Human After All, n.d. Web. 11 Nov. 2015.

The Walrus Donor Report. Rep. N.p.: Walrus Foundation, 2012. Print. The Walrus Donor Report. Rep. N.p.: Walrus Foundation, 2013. Print. The Walrus Donor Report. Rep. N.p.: Walrus Foundation, 2014. Print. The Walrus Donor Report. Rep. N.p.: Walrus Foundation, 2015. Print. The Walrus Talks The Art of Conversation Exit Survey. 16 Oct. 2014. Raw data. Sackville.

The Walrus Talks Energy Exit Survey. 26 May. 2016. Raw data. Edmonton.

“This Drummer Takes Pride in Hitting Like a Girl.” (2015): n. pag. Web.

Timbs, John, 1801-1875. Wonderful Inventions : From the Mariner's Compass to the Electric Telegraph Cable. England; United Kingdom: George Routledge and Sons, 1868. Print.

Time CEO Ripp: We're Not Just a Magazine Company." “Time CEO Ripp: We're Not Just a Magazine Company." Bloomberg, 20 May 2014. Television.

Tuomi, Ilkka. “Chapter 3 Changing Society.” (2005): 1-87. Print.

Turner, John C. Social Identity and Intergroup Relations. Ed. Henri Tajfel. New York: Cambridge University Press, 1982. Print. 
“Tyler Brule Media Maverick.” bloomberg.com. N.p., 1 July 2010. Web. 6 July 2016.

Tylor, E. B. (1896). Writing. Anthropology: An introduction to the study of man and civilization. (pp. 167-181) D Appleton \& Company. doi:http://dx.doi.org.proxy.library.carleton.ca/10.1037/12914-007

Vargo, Jeremy. Ben Rylan, Tom Edwards, and Claire Urbonne, eds. "Episode 185:

Ideas Driving Print." Audio blog post. The Stack. Monocle 24, 12 Mar. 2016. Web. Washington Post. "Stop and Hear the Music" Online video clip. YouTube. 10 April 2007. Web. 5 Feb 2016.

Watson, Steve. "Interview with Steve Watson." Personal interview. 29 Oct. 2016.

Wästlund, Erik, et al. "Effects of VDT and Paper Presentation on Consumption and Production of Information: Psychological and Physiological Factors." Computers in Human Behavior 21.2 (2005): 377-94. Web.

Weingarten, Gene. "Pearls Before Breakfast: Can One of the Nation's Great Musicians Cut through the Fog of a D.C. Rush Hour? Let's Find Out." Washington Post. The Washington Post, 8 Apr. 2007. Web. 29 Feb. 2016.

Wellman, Barry, and Keith Hampton. "Living Networked On and Offline." Contemporary Sociology, vol. 28, no. 6, 1999., pp. 648-654.

Wessel, Maxwell, \& Christensen, Clayton M. "Surviving Disruption." Harvard Business Review. December 2012. 56-65. Print.

"What the Latest USPS Rate Hike Means for Magazines - Folio" (2015): n. pag. Web. "Where Are the U.K. Publishing Startups? - Digiday." (2014): n. pag. Web. "Where Next for Magazines? Top Publishers Envision Their Future Business Models | the Drum." N.p., 1 Dec. 2014. Print. 
"Why Digital Natives Prefer Reading in Print. Yes, You Read That Right.." (2015): n. pag. Web.

Wolfe, Tom. “The Me Decade.” New York Magazine. 23 Aug. 1976. Dec. 8, 2014. Print.

World Wealth Report 2015. Capgemini and RBC Wealth Management, 2015. Print.

Wu, Su. “Art Matters.” NYTimes.com. N.p., 7 May 2014. Web. 26 June 2016.

Zickuhr, Kathryn, and Lee Rainie. Younger Americans and Public Libraries. Pew Reserach Center, 2014. Web.

Wolseley, Roland Edgar. The Changing Magazine: Trends in Readership and Management. New York: Hastings House, 1973. Print.

---. ed. The Magazine World: An Introduction to Magazine Journalism. New York: Prentice-Hall, 1951. Print.

“2010 Census Interactive Population Search.” census.gov. N.p., 2011. Web. 3 Apr. 2016 